\title{
La paz desde abajo: breve historia, impacto del conflicto y participación política de los movimientos sociales en los acuerdos de paz
}

\author{
ANDREA PAOLA BUITRAGO ROJAS
}

$\mathrm{E}_{\mathrm{d}}^{\mathrm{s}}$ ste capítulo tiene por objeto desarrollar una breve reconstrucción de los movimientos sociales feministas, por la diversidad sexual, afrodescendientes e indígenas en Colombia, con el fin de comprender el fundamento y el sentido de la organización, las resistencias y las reivindicaciones en Colombia. Se desarrolla el impacto del conflicto armado sobre las organizaciones y la identidades individuales y colectivas, junto con los procesos de participación y construcción de paz que, desde abajo, han desarrollado una contribución a la paz colombiana en general y específicamente al acuerdo de paz entre el gobierno colombiano y las Farc-EP.

En este sentido es necesario partir de una determinación conceptual sobre el término socio-político de "Movimientos Sociales". Al respecto Snelser (1963) ubica el origen en el contexto de los sesenta, con ocasión del desarrollo de procesos de resistencia que en mayo del 68 impulsaron los movimientos estudiantiles. En 1963, Snelser formuló la Teoría del Comportamiento Colectivo, que define los Movimientos Sociales como actores colectivos que ejercen el emprendimiento sobre grupos marginados que, a partir de un apoyo colectivo, buscan algún tipo de reivindicación. Para la teoría de la movilización de los recursos, 
los movimientos sociales son actores colectivos que evalúan el costo y el beneficio de sus movilizaciones a corto, mediano y largo plazo en un espacio democrático. Estos son fundamentales para dinamizar y renovar las estructuras de poder. En las teorías contemporáneas, como es la propuesta de Charles Tilly (2005) que elabora una "Teoría de los nuevos movimientos sociales" se plantea la la acción política en el espacio de las Tecnologías de la Información y la Comunicación - TIC-, que permiten construir redes con distintas identidades colectivas en las que se desarrolla un escenario de luchas ideológicas que tienen un efecto material y virtual en los procesos de construcción del poder y propician una resistencia crítica.

En Colombia, se destaca el aporte teórico de Orlando Fals Borda quien definió los Movimientos Sociales como una forma de construcción alternativa de relaciones de poder, que se caracterizan por permanecer en el tiempo, y se expanden en el territorio y cuyo objetivo principal es la creación de una cultura política propia, mediante la cual se procuran procesos de cambio social que buscan influir en el orden social. En las propuestas actuales, se destacan los estudios del investigador Mauricio Archila que define los movimientos sociales como sujetos colectivos cuya finalidad es la afirmación, construcción y transformación de los derechos.

En este sentido, la siguiente reflexión se refiere a los movimientos sociales, movilizados por varias organizaciones que han contribuido a la fundación histórica y a la memoria y sus reivindicaciones: el sexo, el género, la raza y la etnia.

\section{Desarrollo del movimiento feminista ${ }^{2}$ en Colombia}

\section{Breve historia del movimiento feminista en Colombia}

De acuerdo con Norma Villarreal (2009), las luchas iniciales en defensa de la mujer en la política se ubican en la época de la masacre de las bananeras, cuando se fundaron en Colombia las organizaciones gremiales,

2 El concepto de feminismo que se desarrolla en este apartado hace referencia a un tipo de expresión de identidad de sexo que corresponde al de la mujer. 
étnicas y de izquierda que, ante las explotaciones petroleras, exigieron algún tipo de reivindicación. En las primeras expresiones políticas de la mujer en Colombia, se encuentra la firma de un Manifiesto en defensa de la soberanía y la independencia de Panamá en 1903, que contó con 300 firmas de mujeres. La primera lucha por la defensa de la mujer en Colombia se encuentra relacionada con las luchas indígenas de Manuel Quintín Lame, en el primer manifiesto sobre los derechos de la mujer indígena en Colombia, promulgado y aceptado por 14000 mujeres indígenas.

En 1917, se conforma la primera organización que persigue la defensa de la mujer, llamada "Centro de Emancipación Femenina", en la ciudad de Montería. Allí se destaca la figura de Betsabé Espinoza, una líder que defendió los derechos de la mujer, y que en Antioquia logró el aumento del $40 \%$ del salario de las trabajadoras.

La creación de instituciones de ahorro de mujeres fue el reflejo material del empoderamiento de la mujer. Es el caso de las Cajas de Ahorro que fueron establecimientos que permitían la liberación de la mujer. Esta iniciativa fue rechazada por la ideología conservadora de esa época. Estas organizaciones fueron formas de reconocimiento de la reforma legal determinada en la Ley 08 de 1922 en oposición al artículo 128 del Código Civil (Ley 57 de 1887, 26 de mayo), reprochado por los liberales:

Del 15 de julio al 20 de diciembre de 1918, se publicó en el Correo liberal, un provocador aviso que bajo el título la mujer esclava, transcribía el artículo 128 del Código Civil, según el cual, la mujer casada sin autorización del marido no podía celebrar contrato, aceptar herencia, donación, adquirir, enajenar, hipotecar o empeñar algún bien. (Villareal, 2009, p. 72)

Una consecuencia del desarrollo urbano fue la migración del campo a la ciudad, que dio lugar a un tipo inédito de relaciones maritales que permitían superar el patriarcado en el matrimonio. Surgió, entonces, el amor libre y las transformaciones morales del sistema patriarcal tradicional, arraigado especialmene en el campo. La migración a la ciudad permitió acceder a la educación a las clases alta y media, lo que permitió la inclusión de la mujer en la producción literaria y dio lugar 
a la crítica teórica del sistema patriarcal. Se destaca la figura de Soledad Acosta en el periodismo crítico:

A través del ejercicio intelectual, las mujeres se pensaron como seres excluidos de las grandes decisiones, y desde este campo; en que eran valoradas, comenzaron su crítica. [...] Desde finales del siglo XIX, Soledad Acosta de Samper, autora de excepcionales dotes y muy prolífica, se mostró como una de las defensoras de las nuevas opciones para la mujer en una monografía titulada Aptitud de la mujer para ejercer todas las profesiones y el periodismo en Hispanoamérica. (Villareal, 2009, p. 67)

Entre 1920 y 1927, la mujer ingresa a la educación superior, en las áreas de la docencia y la cultura. En 1923, se crean las primeras sala-cunas en las empresas, lo que favoreció los derechos de las mujeres maternas trabajadoras, y en 1925, se produce la primera movilización de mujeres contra la pena de muerte y la participación en los partidos políticos de izquierda. Una muestra es el Partido Socialista donde se da una movilización obrera de mujeres trabajadoras que, de acuerdo con Villareal (2009), este hecho fue registrado en un torneo que llevaba por nombre:

La Flor del Trabajo, un torneo galante que se clausuraba con la elección nacional de una dama escogida en competencia, con representantes de distintas regiones. Ganaba la que aportaba más votos "para obras de beneficio del obrerismo". El voto valía diez centavos que pagaban según la simpatía y el encanto. (Villareal, 2009, p. 73)

Este tipo de expresiones permitían hacer un homenaje a la labor de María Cano, que fue opacada por el desarrollo patriarcal que asumieron los sindicatos.

La década de los años treinta fue un periodo de integración de los derechos civiles y políticos de la mujer en Colombia cuando, de acuerdo con Lola Luna (1985), se extendió el protagonismo de la mujer hasta 1957. Este protagonismo se manifestó en las discusiones de prensa en esta época, respaldados por el liderazgo del liberalismo en Colombia junto con los procesos de modernización. En este marco, se instituye la defensa del voto de la mujer y el reconocimiento de este derecho en 1954 por Gustavo Rojas Pinilla. 
Pero por estar en periodo de la dictadura del general Gustavo Rojas Pinilla, se vino a ejercer ese voto tres años después, cuando las mujeres participaron en el plebiscito que cerró el gobierno militar y abrió el régimen de coalición bipartidista del Frente Nacional. Esto significa que, aunque hubo casos de participación femenina en política antes de esas fechas, como fue María Cano en los años 20 y Mercedes Abadía u Ofelia Uribe en los 40, solo hasta los 50 la mujer en Colombia puedo elegir y ser elegida. (Archila, 2013, p. 7)

Luna (1985) divide las reivindicaciones de la mujer en Colombia en los siguientes escenarios: 1930-1940, época de construcción colectiva de consciencia de la defensa de la mujer en materia de educación e independencia económica; 1944-1948, periodo de reivindicación del voto femenino junto con las alianzas internacionales por la defensa femenina; 1949-1957, se reconoce el derecho al voto y empieza el periodo de la violencia en Colombia.

Este panorama de cambio de la reivindicación femenina tiene un trato especial y significante en la Constitución de 1991 con la renovación del Estado y la apertura al pluralismo jurídico que introdujo cambios significativos en la comprensión jurídica de la mujer, aunque, en la vida política se mantuvo el desarrollo de los roles en las esferas pública y privada. Este escenario es expresado en la Sentencia C-371 (2000) de la Corte Constitucional que estudia la constitucionalidad de la Ley de Cuotas en favor de la mujer. La Corte manifiesta que "la mujer y el hombre tienen iguales derechos y oportunidades" y que "la mujer no podrá ser sometida a ninguna clase de discriminación" (Sentencia C-371, 2000). Igualmente en esta sentencia se determina el desarrollo cronológico de los derechos de la mujer que se resumen a continuación:

- Ley 83 de 1931, permitió a la mujer trabajadora recibir directamente su salario.

- Ley 28 de 1932, reconoció a la mujer casada la libre administración y disposición de sus bienes y abolió la potestad marital, de manera que el hombre dejó de ser su representante legal. 
- Decreto 1972 de 1933 se permitió a la población femenina acceder a la Universidad.

- 1938, protección a la maternidad acorde con las pautas dadas por la OIT en 1919.

- 1954 Reconocimiento del Derecho al Sufragio.

- 1957 Ejercicio del Derecho al Sufragio.

- Decreto 2351 de 1965, se prohibió despedir de un empleo a la mujer en estado de embarazo.

- Las leyes $1^{\text {a }}$. de 1976 y 75 de 1968 , igualdad de los sexos ante la ley.

- Decreto 2820 de 1974 concedió la patria potestad tanto al hombre como a la mujer, eliminó la obligación de obediencia al marido, y la de vivir con él y seguirle a donde quiera que se trasladase su residencia.

- Artículo 94 decreto ley 999 de 1988 abolió la obligación de llevar el apellido del esposo.

- Ley 50 de 1990, ampliación de la maternidad de 8 a 12 semanas.

Para reconocer los derechos de la mujer en materia civil y laboral, y para no limitar los derechos políticos de la mujer solo al ejercicio del voto, se elaboró un estudio detallado de las relaciones patriarcales en la formación y el ejercicio profesional de la mujer, y el impacto de la falta del empoderamiento en las instituciones público-privadas, que se mostrará a continuación: 
Tabla 2. Número de graduados de educación superior.

Promedio años 1990 a 1997

\begin{tabular}{|c|c|c|c|c|c|c|c|c|}
\hline $\begin{array}{c}\text { Nivel de } \\
\text { formación }\end{array}$ & \multicolumn{2}{|c|}{ Tecnológica } & \multicolumn{2}{c|}{ Universitaria } & \multicolumn{2}{c|}{ Especializada } & \multicolumn{3}{c|}{ Maestría } \\
\hline & masc. & fem. & masc. & fem. & masc. & fem. & masc. & fem. \\
\hline Total nacional & 49060 & 55275 & 189477 & 232123 & 35727 & 45997 & 5983 & 6031 \\
\hline
\end{tabular}

Fuente: Sentencia de la Corte Constitucional (Sentencia C-371, 2000).

Tabla 3. Porcentaje de mujeres senadoras y representantes

\begin{tabular}{|c|c|c|}
\hline \multirow{2}{*}{ Periodo } & Senado & Cámara \\
\cline { 2 - 3 } & \% mujeres senadoras & $\%$ mujeres representantes \\
\hline $1991-1994$ & $7.29 \%$ & $8.6 \%$ \\
\hline $1994-1998$ & $6.48 \%$ & $12.7 \%$ \\
\hline $1998-2000$ & $13.43 \%$ & $11.8 \%$ \\
\hline
\end{tabular}

Fuente: Sentencia de la Corte Constitucional (Sentencia C-371, 2000).

Tabla 4. Porcentaje de mujeres que han ocupado la presidencia y vicepresidencia del Senado y la Cámara

\begin{tabular}{|c|c|c|c|c|}
\hline \multirow{2}{*}{ Periodo } & \multicolumn{2}{|c|}{ Senado } & \multicolumn{2}{c|}{ Cámara } \\
\cline { 2 - 5 } & $\begin{array}{c}\% \text { mujeres } \\
\text { Presidentas }\end{array}$ & $\begin{array}{c}\% \text { mujeres } \\
\text { vicepresidentas }\end{array}$ & $\begin{array}{c}\% \text { mujeres } \\
\text { Presidentas }\end{array}$ & $\begin{array}{c}\% \text { mujeres } \\
\text { vicepresidentas }\end{array}$ \\
\hline $1991-1994$ & $0 \%$ & $0 \%$ & $0 \%$ & $0 \%$ \\
\hline $1994-1998$ & $0 \%$ & $0 \%$ & $0 \%$ & $20 \%$ \\
\hline $1998-2000$ & $0 \%$ & $0 \%$ & $0 \%$ & $0 \%$ \\
\hline
\end{tabular}

Fuente: Sentencia de la Corte Constitucional (Sentencia C-371, 2000). 
Tabla 5. Porcentaje de mujeres magistradas (titulares) en las altas cortes

\begin{tabular}{|c|c|c|c|c|}
\hline Año & $\begin{array}{c}\text { Corte Suprema } \\
\text { de Justicia }\end{array}$ & $\begin{array}{c}\text { Consejo } \\
\text { de Estado }\end{array}$ & $\begin{array}{c}\text { Consejo S. } \\
\text { de la Judicatura }\end{array}$ & $\begin{array}{c}\text { Corte } \\
\text { Constitucional }\end{array}$ \\
\hline 1992 & $0 \%$ & $14.8 \%$ & $23.07 \%$ & $0 \%$ \\
\hline 1993 & $0 \%$ & $14.8 \%$ & $23.07 \%$ & $0 \%$ \\
\hline 1994 & $0 \%$ & $14.8 \%$ & $23.07 \%$ & $0 \%$ \\
\hline 1995 & $0 \%$ & $14.8 \%$ & $23.07 \%$ & $0 \%$ \\
\hline 1996 & $0 \%$ & $14.8 \%$ & $23.07 \%$ & $0 \%$ \\
\hline 1997 & $0 \%$ & $14.8 \%$ & $23.07 \%$ & $0 \%$ \\
\hline 1998 & $0 \%$ & $14.8 \%$ & $23.07 \%$ & $0 \%$ \\
\hline 1999 & $0 \%$ & $11.11 \%$ & $30.7 \%$ & $0 \%$ \\
\hline 2000 & $0 \%$ & $11.11 \%$ & $30.7 \%$ & $0 \%$ \\
\hline
\end{tabular}

Fuente: Sentencia de la Corte Constitucional (Sentencia C-371, 2000).

Tabla 6. Porcentaje de mujeres abogado auxiliar o magistrado auxiliar en las altas Cortes, periodo 1999

\begin{tabular}{|c|c|c|c|}
\hline $\begin{array}{c}\text { Corte Suprema } \\
\text { de Justicia }\end{array}$ & $\begin{array}{c}\text { Consejo } \\
\text { de Estado }\end{array}$ & $\begin{array}{c}\text { Consejo Superior } \\
\text { de la Judicatura }\end{array}$ & $\begin{array}{c}\text { Corte } \\
\text { Constitucional }\end{array}$ \\
\hline $26 \%$ & $50 \%$ & $39 \%$ & $56 \%$ \\
\hline
\end{tabular}

Fuente: Sentencia de la Corte Constitucional (Sentencia C-371, 2000).

Tabla 7. Porcentaje de mujeres ministras y viceministras

\begin{tabular}{|c|c|c|}
\hline Año & Ministras & Viceministras \\
\hline 1990 & $7.14 \%$ & $21.4 \%$ \\
\hline 1991 & $7.14 \%$ & $7.14 \%$ \\
\hline 1992 & $7.14 \%$ & $21.4 \%$ \\
\hline 1993 & $7.14 \%$ & $7.14 \%$ \\
\hline 1994 & $13.3 \%$ & $13.3 \%$ \\
\hline 1995 & $13.3 \%$ & $0 \%$ \\
\hline
\end{tabular}




\begin{tabular}{|c|c|c|}
\hline Año & Ministras & Viceministras \\
\hline 1996 & $12.5 \%$ & $6.25 \%$ \\
\hline 1997 & $6.25 \%$ & $6.25 \%$ \\
\hline 1998 & $12.5 \%$ & $12.5 \%$ \\
\hline 1999 & $\mathrm{Nd}$ & $\mathrm{Nd}$ \\
\hline 2000 & $\mathrm{Nd}$ & $\mathrm{Nd}$ \\
\hline
\end{tabular}

Fuente: Sentencia de la Corte Constitucional (Sentencia C-371, 2000).

Tabla 8. Porcentaje de inscritos en la carrera administrativa

\begin{tabular}{|c|c|}
\hline Hombres & Mujeres \\
\hline $46 \%$ & $54 \%$ \\
\hline
\end{tabular}

Fuente: Sentencia de la Corte Constitucional (Sentencia C-371, 2000).

Tabla 9. Participación porcentual de la mujer en cargos de elección popular en el ámbito territorial (según lista de elegidas)

\begin{tabular}{|l|c|c|c|}
\hline \multirow{2}{*}{\multicolumn{1}{|c|}{ Cargo }} & $1993-1995$ & $1995-1997$ & $1998-2000$ \\
\cline { 2 - 4 } & Mujeres & Mujeres & Mujeres \\
\hline Gobernador/a & $3.7 \%$ & $6.25 \%$ & $0 \%$ \\
\hline Alcalde/sa & $5.5 \%$ & $5.87 \%$ & $5.04 \%$ \\
\hline Asambleas Departamentales & $10.1 \%$ & $11.35 \%$ & $14.57 \%$ \\
\hline Concejos Municipales & $5.2 \%$ & $9.71 \%$ & $10.32 \%$ \\
\hline
\end{tabular}

Fuente: Sentencia de la Corte Constitucional (Sentencia C-371, 2000).

Tabla 10. Participación femenina en los órganos de control —en propiedad-

\begin{tabular}{|c|c|c|}
\hline Periodo & Procuradora & Contralora \\
\hline $1990-2000$ & $0 \%$ & $0 \%$ \\
\hline
\end{tabular}

Fuente: Sentencia de la Corte Constitucional (Sentencia C-371, 2000). 
Tabla 11. Participación de la mujer en los sindicatos

\begin{tabular}{|c|c|}
\hline Estatal & Privado \\
\hline $42.5 \%$ & $24 \%$ \\
\hline
\end{tabular}

Fuente: Sentencia de la Corte Constitucional (Sentencia C-371, 2000).

Tabla 12. Participación de la mujer en las centrales sindicales

\begin{tabular}{|c|c|}
\hline Central Sindical & Participación en cargos directivos \\
\hline CTC & $6.2 \%$ \\
\hline CGTD & $3.3 \%$ \\
\hline CUT & $14.3 \%$ \\
\hline
\end{tabular}

Fuente: Sentencia de la Corte Constitucional (Sentencia C-371, 2000).

Esta información contrasta con el ingreso de la mujer a la educación, que supera en un alto porcentaje a la de los hombres. No obstante, la participación femenina es escasa aún en los cargos directivos y decisorios del Estado, donde se observa una mayor presencia de mujeres en el Ministerio de Educación. Así mismo, persiste la creencia popular de que la participación femenina se da especialmente en las elecciones al decidir quiénes serán los gobernantes, lo que es una limitada por no afirmar anulada participación. Además, en las urnas, la elección de las mujeres es muy escasa, y en los equipos de gobierno, se tiene la presencia femenina especialmente en las secretarías. La rama judicial también cuenta con una alta participación femenina. En cambio, en el sindicalismo, la elección de mujeres en cargos directivos es prácticamente nula. Esto permite reiterar la teoría de las paredes de vidrio de María Emma Wills (2007), confirmada por Mauricio Archila (2013):

Pero, como dice María Emma Wills (2007), hay segmentación por áreas, pues todavía siguen siendo predominantemente femeninas algunas profesiones asociadas con el cuidado del hogar y las labores de asistencia social como enfermería y trabajo social. Esto es lo 
que ella llama "paredes de vidrio" que impiden a las mujeres entrar masivamente a profesiones “masculinas”. (Archila, 2013, p. 5)

Mauricio Archila (2013) realiza un estudio sobre el desarrollo de las luchas sociales en Colombia y su relación con las mujeres en los siglos xx y xxi, articulando el proceso de educación y de inmersión laboral de la mujer con el proceso de participación política, lo que se refleja en los cambios sociales en favor de la mujer en la historia de Colombia. Se destaca que solo el $3 \%$ de sus luchas representan luchas en favor de la mujer y el porcentaje restante se asocia a lucha en relación con el conflicto armado o con otras materias de reivindicación social común, lo que demuostra el impacto del conflicto sobre la defensa de la mujer, pues, al ubicarse como un punto de afectación inmediata, termina por constituirse en el centro de las reivindicaciones de la mujer, dejando en segundo plano la reivindicación del género.

Este rasgo, más que una debilidad o una fortaleza intrínseca de los movimientos de mujeres, es resultado de las condiciones en las que se desenvuelven en el país en el marco de una cultura patriarcal y excluyente que nos caracteriza aun en nuestros días. (Archila, 2013, p. 11)

En las luchas sociales donde han participado mujeres con ocasión del conflicto armado, expresa Archila (2013) en la siguiente figura que ubica entre el periodo (1975-2012) que después de 1999-2000 se han fortalecido los movimientos de víctimas del conflicto armado, desde los cuales rechazan la muerte y la guerra con sus efectos, bajo la condición de madre, de hija, de esposa, de tía y/o abuela, asumiendo una connotación especial de roles sociales desplegados en la guerra. Así como también la construcción y el rechazo a su corporeidad como campo de batalla, desde donde se narran los sufrimientos que dejan la guerra. Esta es la participación de las mujeres en las luchas sociales, en la construcción de foros y de las narrativas de la memoria desde donde se busca la construcción de lo público al narrar los asuntos privados y públicos que devastaron su condición sobrepasando la reflexión aislada de su género, dando una connotación especial a este movimiento en Colombia. 
Figura 3. Luchas sociales en Colombia y luchas de mujeres y de víctimas del conflicto armado, 1975-2012

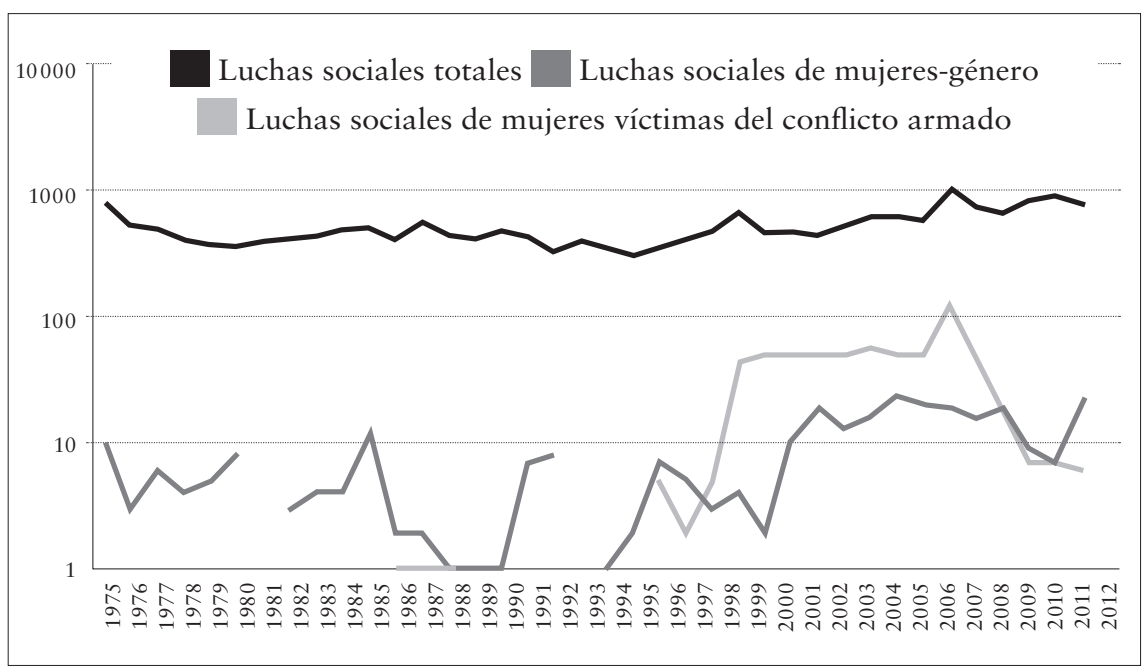

Fuente: Mauricio Archila (Archila, 2013, p. 10).

Figura 4. Luchas de mujeres y de víctimas del conflicto armado, 1975-2012

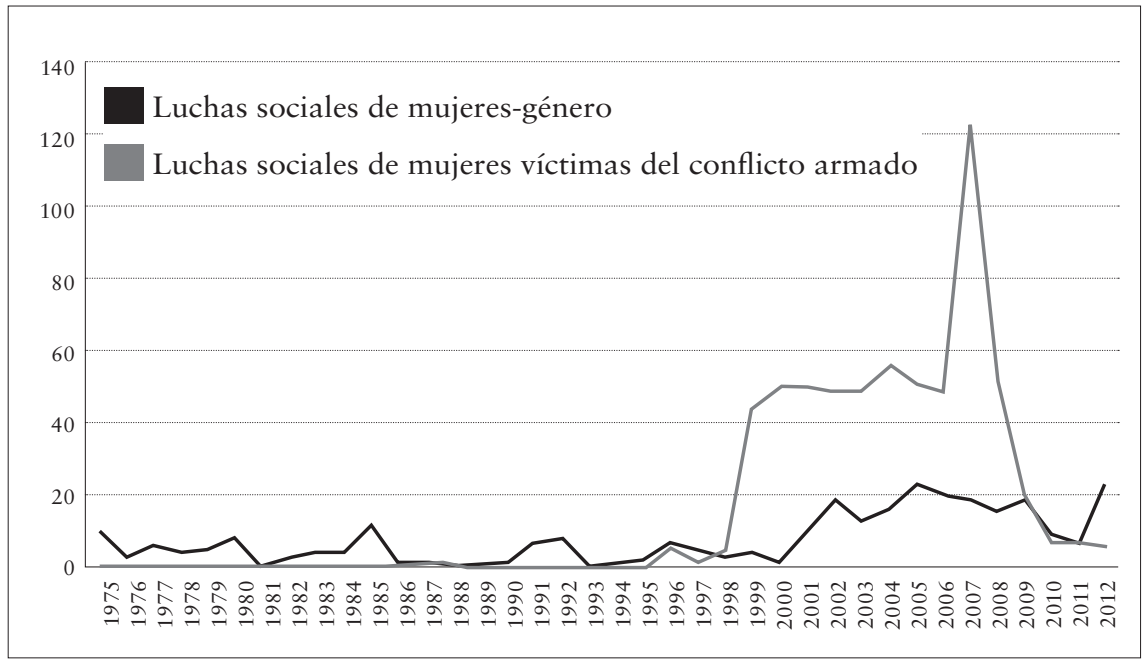

Fuente: Mauricio Archila (Archila, 2013, p. 11). 
Figura 5. Motivos de las luchas de mujeres y de las víctimas, 1975-2012

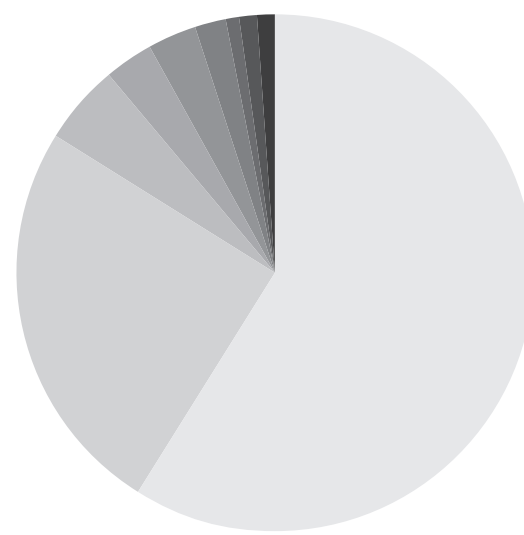

\begin{tabular}{|lr}
\hline Derechos & $59 \%$ \\
\hline Políticas & $25 \%$ \\
\hline Hábitat & $5 \%$ \\
\hline Conmemoración & $3 \%$ \\
\hline Hábitat & $3 \%$ \\
Servicios sociales & $2 \%$ \\
Ambientales & $1 \%$ \\
\hline Autoridades & $1 \%$ \\
\hline Incumplimiento pactos 1\%
\end{tabular}

Fuente: Mauricio Archila (Archila, 2013, p. 12).

De acuerdo con las figuras 3, 4 y 5, Archila (2013) propone que la actual fase se inserta en el requerimiento de derechos en un primer plano y en un segundo lugar lo político, teniendo en común la búsqueda de reconocimiento como víctimas del conflicto armado de una serie de derechos que permitan la reparación de los daños ocasionados. Se incluye el cambio del sistema productivo con la introducción de los TLC y los avances en matera reproductiva.

Este contexto lo expresan movimiento actuales, como es la Ruta Pacífica de las Mujeres y la Alianza Iniciativas de Mujeres por la Paz, la primera creada en 1996 en Antioquia con ocasión de la guerra en este territorio y la segunda, creada con ocasión de la búsqueda por la paz por grupos de mujeres, lo que no implica que estas organizaciones sean feministas.

Si bien falta mucho por lograr, es notorio lo conseguido, y eso se debe en gran parte a los fines y medios usados por las mujeres y sus aliados. No sobra recordar que bajo la consigna de "lo privado es público" los movimientos de mujeres siempre han trastocado la separación entre las dos esferas. Así mismo, su relación con el Estado es menos antagónica que la de otros movimientos sociales, lo cual no quiere decir que sean poco autónomas. En síntesis, 
podemos decir que las recientes acciones colectivas de las mujeres en Colombia avanzan en la construcción de una ciudadanía no uniforme, que suponga más equidad pero respete las diferencias. (Archila, 2013, p. 24)

Entre las asociaciones de mujeres se encuentran aquellas cuyo núcleo central es la construcción de la paz en Colombia, tomando como punto de partida el lugar de la mujer en la guerra, con el fin de lograr beneficios en favor de la mujer. Entre estas, se encuentran organizaciones como la Ruta Pacífica de las Mujeres, la Red Nacional de mujeres, entre otras que, de acuerdo con una investigación realizada por Mariana Tafur (2011), estas organizaciones proponen la construcción de paz según el feminismo, puesto que es el estudio de las dinámicas del poder el punto de partida del sistema de dominación del hombre sobre la mujer. Esta dominación deriva en la discriminación y produce un discurso que guarda la misma relación con el fenómeno bélico, puesto que allí también se dan procesos de dominación.

La cultura patriarcal es una de las bases de la cultura militarista, porque se basa en la dominación de un sexo sobre otro, en la asignación autoritaria de un papel social que establece una desigualdad beneficiando solo a una parte. La cultura militarista también es una de las bases de la cultura patriarcal porque la lógica amigo-enemigo, la respuesta violenta a los conflictos o la organización vertical/autoritaria son características militares que potencian y justifican en última instancia el control patriarcal de la sociedad. (Sánchez 45)

Es preciso notar que, como ya se ha venido insinuando, el conflicto colombiano le imprime características específicas a los movimientos. Las integrantes son mujeres que, como bien lo dice Cynthia Cockburn (2009), decidieron organizarse colectivamente en oposición a la guerra y al militarismo, con el fin de replantearse el orden social y conseguir la paz. Porque:

No es suficiente equilibrar la representación de las mujeres en la esfera de lo público y lo político (paridad), sino que es obligado enmarcar los otros niveles de la realidad, la cultura, la sociedad, 
la escala de valores bajo el sesgo que el feminismo aporta. (Miyares, citada por Tafur, 2011, p. 15)

La conformación de movimientos sociales ha expresado el desarrollo de valores que, en concordancia con Tafur (2011), crean un espacio para reflexionar sobre la Paz desde la perspectiva de la mujer, como es el caso de "cooperación, bondad verbal, bondad física, equidad, libertad, solidaridad y legitimación de la paz" (Tafur, 2011, p. 17). En la Red Nacional de Mujeres, cuya directora es la investigadora Doris Lamus, aparece como constante la necesidad de incorporar a la mujer en la reflexión sobre la guerra, con la libertad como elemento constante en la reflexión de la lucha contra la subordinación, en relación con la solidaridad en los procesos de intervención y colaboración con las mujeres que han vivido la guerra de manera directa. Estas mujeres necesitan apoyo en la narración de la violencia y la guerra, como punto de partida para la construcción de la paz.

En el movimiento Mujeres, Derechos Humanos y Paz en Colombia, cuya líder es Gloria Tobón, el valor de la bondad verbal acompañado de la libertad y la equidad es el fundamento de su acción. En este horizonte, el movimiento invita a la reconciliación y al diálogo para constituir la paz con la reivindicación de la mujer que ha sufrido la guerra como botín de guerra y ha sido violada y maltratada. Por eso, es necesaria la reivindicación de la libertad y de la equidad, puesto que estas aseguran el desarrollo económico y político de la sociedad para que los hechos violentos no vuelvan a repetirse. De acuerdo con Tafur (2011), Gloria Tobón ha representado:

El discurso de Gloria Tobón, Mujeres, DDH y paz en Colombia, se denuncian las violaciones a los Derechos Humanos y al Derecho Internacional Humanitario en el país. La autora no hace referencia al valor de la cooperación pero sí a la bondad verbal, cuando asegura que "las feministas estamos convencidas que la salida a las consecuencias trágicas de este conflicto, es política y de diálogo" (Tobón, 2008:9); esta afirmación va seguida de una negación rotunda a la lucha armada y a la violencia directa, lo que lleva a decir que en este discurso también se tiene en cuenta la bondad física en el marco del conflicto armado. En cuanto a la libertad expresada 
como ausencia de subordinación, se condena la violencia sexual de género perpetuada por los grupos armados y se condenan los secuestros. (Tafur, 2011, p. 18)

En la acción de la Ruta Pacífica de las Mujeres, se suele narrar la violencia como resistencia ante el fenómeno bélico. Se enfrenta la violencia mediante el ejercicio práctico de la no violencia en los escenarios narrados. También se articulan prácticas de transformación cultural sobre la estructura patriarcal que, de acuerdo con Tafur (2011), ha sido el ejercicio de la bondad verbal y física la principal característica del movimiento:

La bondad verbal se expresa a partir de apartados en los que Sánchez asegura que las palabras han sido instrumentos para enfrentar el poder del patriarcado. La bondad física, a partir de las movilizaciones no violentas, han servido para el mismo fin. (Tafur, 2011, p. 20)

Estas tres organizaciones examinadas por Tafur (2011), además de interesarse por la protección y la reivindicación de la mujer, tienen en común el desarrollo de prácticas socio-culturales que propenden por la paz, como la participación en foros, derivados del Acuerdo de la Habana que en consonancia con Archila, este ha sido el escenario real y mayoritario en el que se ha examinado la movilización feminista en Colombia:

A modo de síntesis podemos decir que la acción de los grupos de mujeres y, dentro de ellos de las feministas, muestra una presencia social y política sin acudir mucho a las protestas, pero con gran eficacia a la hora de las modificaciones legales y, algo más importante todavía, de las prácticas cotidianas. Eso impacta al conjunto de la sociedad y de alguna manera da cuenta de las variaciones estructurales en la condición de la mujer que observábamos en la primera parte de esta presentación. Tal vez por ello reciben tanta violencia en su contra, lo que también constituye una modalidad reciente para debilitar actores sociales como el sindicalismo y el movimiento indígena, entre otros. El problema de la violencia, sobre todo en los años ochenta, las 
hizo movilizarse y en ocasiones tomar el papel de vanguardia en la búsqueda de la paz. [...] Aquí no son únicamente los papeles tradicionales los que las motivan, sino una actitud distinta ante la guerra. (Archila, 2013, p. 24)

\section{El impacto del conflicto armado en la mujer}

El impacto del conflicto armado sobre las mujeres se ha determinado por organizaciones de mujeres de víctimas del desplazamiento y por defensores y defensoras de derechos humanos un importante trabajo de documentación que muestra la violencia contra la mujer en Colombia en el escenario bélico. Este trabajo expresa un aporte cuantitativo y cualitativo en el análisis de las tácticas y estrategias que en la guerra son empleadas contra la mujer, requiriendo una reparación y una protección especial. Al respecto, se hará un breve recuento de estos documentos desde el año 2000 hasta 2015, con el fin de resaltar al impacto y desarrollo del conflicto armado sobre la mujer, considerando como variable paralela la desmovilización del paramilitarismo con la Ley 975 de 2005 y los procesos de protección, garantías y reparación de víctimas que de manera legal el Estado colombiano ha venido incorporando. Los informes que se tomaron para expresar esta información corresponden al trabajo de la Mesa Mujer y Conflicto armado, la organización Sisma Mujer y la visita que realizó la Comisión interamericana de Derechos Humanos en 2005.

El primer avance de informe sobre violencia contra las mujeres y niñas en el conflicto armado colombiano realizado por la Mesa de trabajo "Mujer y Conflicto armado", presentado en abril de 2011, revela el incremento de la violencia sociopolítica contra la mujer en Colombia. Se dice que, en 1988, se tenía un promedio de 10 mujeres asesinadas, en 2000 se tuvo un aumento en la cifra, pasando a 20 víctimas por día. En este mismo año, la cifra de personas desplazadas fue de 2000000 , de los cuales el $49 \%$ fueronresponsabilidad de los paramilitares, el $28 \%$ de grupos guerrilleros y el $5 \%$ de las Fuerzas militares. Estos datos permiten dimensionar el impacto del paramilitarismo en el desplazamiento y en el desarrollo de la violencia contra la mujer, a lo cual se añade el $98 \%$ de impunidad de estos delitos. En las ejecuciones 
extrajudiciales, este informe documenta el paso de una mujer cada día y medio en 1999 a una mujer cada día en 2000.

Estas cifras, según el informe, señalan las consecuencias del desplazamiento en las mujeres que deben asumir la jefatura del hogar con ocasión del asesinato de sus esposos o en ocasiones, debido al desconsuelo que produce el desplazamiento en sus familiares, son ellas las encargadas de asumir el liderazgo en la familia. Se adjudican labores de reproducción y producción en el hogar. Se estima que el $50 \%$ de los desplazados son mujeres, de las cuales, $31 \%$ de las mujeres han asumido la jefatura del hogar y el $55 \%$ de los desplazados son menores de 18 años, lo que implica que son niñas y niños que quedan con sus madres después de sufrir la violencia. También se documentan casos de mujeres que viven violencias en la familia que nunca habían sufrido.

Las mujeres líderes de organizaciones sufren el desplazamiento al ser perseguidas por grupos armados que las señalan de tener nexos con algún otro grupo armado, de modo que quedan condenadas a irse a otra parte. Entre las organizaciones de mujeres más afectadas se encuentran ofP, Organización Femenina Popular ubicada en el territorio de Barrancabermeja y Magdalena Medio, cuya principal labor es ayudar a los desplazados y capacitar en derechos humanos y de desarrollo con perspectiva de género; ANMUCIC, Asociación Nacional de Mujeres Campesinas e Indígenas de Colombia que trabaja con 90000 víctimas del desplazamiento y del conflicto armado.

La violencia sexual se da cuando se usa el sexo como una expresión de dominio, terror y control del territorio y de un grupo social mediante el cuerpo de las mujeres. También se documenta la violencia como práctica de tortura y de deshonra contra el enemigo. La violencia contra niñas en el conflicto armado es otro asunto que se expresa con mayor gravedad. Muchas niñas son seducidas sentimentalmente con el fin de reclutarlas, lo que hace difícil la determinación del reclutamiento forzado de menores. Esta práctica, en un $50 \%$ se perpetra por paramilitares y el $40 \%$ por grupos guerrilleros.

La pobreza de las mujeres en Colombia alcanza el $54 \%$, de las cuales el $25 \%$ son jefes de hogar. Esta cifra se se complementa con la del maltrato conyugal que llega al $67.8 \%$, del cual, el $92 \%$ se presenta contra las mujeres. 
Anualmente, el Instituto de Medicina Legal consigna un promedio de 9500 casos de violencia física y 9300 casos de abuso sexual contra niñas y niños. Sin embargo, el subregistro de los casos de violencia intrafamiliar es muy alto. Muchas mujeres no denuncian las agresiones de las cuales son víctimas ellas o sus hijas e hijos, bien porque consideran la violencia como algo "normal" en las relaciones familiares, o por temor a las represalias de su compañero. (Mesa de Trabajo "Mujer y Conflicto Armado" 16)

En el año 2001, se publicó el Informe sobre violencia sociopolítica contra mujeres y niños en Colombia en el mes de noviembre en la ciudad de Bogotá por la Mesa Mujer y Conflicto armado. En este documento, se presentan las violaciones a los Derechos Humanos y al Derecho Internacional Humanitario entre octubre 2000 y marzo de 2001. Allí, se relacionan 20 personas asesinadas por día, para un total de 3274 personas que sufrieron violencia sociopolítica, entre las cuales, se documentan 67 niñas y niños asesinados, 93 mujeres jóvenes y 163 mujeres adultas. El desplazamiento es otro crimen al que se hace alusión, respecto al cual se dice que $58 \%$ son mujeres, de las cuales $40 \%$ son viudas y $18 \%$ fueron abandonadas después de llegar a la ciudad. Se relaciona también el delito de retención o secuestro temporal por actores armados con el fin de abusar sexualmente de sus víctimas o utilizarlas para el trabajo doméstico. Además, se indica que la violencia intrafamiliar se agudizó por causa del estrés postraumático producido por el desplazamiento.

En 2002, la Mesa Mujer y Conflicto Armado publicó el tercer informe sobre la violencia sociopolítica contra mujeres y niños. El informe expresa que la cifra del desplazamiento en Colombia corresponde a 138970 personas desplazadas entre enero y junio de 2002. De estas, el $47.6 \%$ fueron mujeres y menores de edad $44.5 \%$. El informe buscó cruzar el enfoque de género con el enfoque étnico, y encuentra el impacto sobre las mujeres afrodescendientes e indígenas en Colombia, y revela cifras del impacto sobre las mujeres afro con ocasión de la violencia perpetrada por actores armados en contra de su cuerpo y su territorio, lo que propicia violencia sexual, intimidar y estigmatizar a estas mujeres. 
El racismo que prevalece en la sociedad colombiana, está presente también en la manera como los actores armados reproducen, en su relación con las mujeres afrocolombianas, prácticas excluyentes, discriminatorias y desconocedoras de las diferencias. "A muchos no les agrada nuestro color quizá... nuestra forma de ser, nuestra forma de pensar, y quizás no existe un golpe pero sí una mala mirada y para nosotras eso es más que un golpe, porque esa mirada se queda clavada en nuestros corazones y a diario notamos que es que no les agradamos a ellos. A ellos (armados) uno alcanza a diferenciar que ellos llegan a una parte y hay una "clarita" y no la gritan de la misma manera como lo gritan a uno, o quizá no la empujan como la empujan a uno. O sea que entre nosotros los negros todavía sigue existiendo la idea de que a nosotros nos quieren tener a diario pisados y a diario menospreciados, eso sí existe. (Mesa de Trabajo "Mujer y Conflicto armado", 2002, p. 27)

Se documenta el asesinato de mujeres líderes, lo que afecta el desarrollo de los procesos culturales y políticos propios de la comunidad, y desestructura el sentido de unidad y las prácticas culturales de los afrodescendientes, pues impiden los ritos funerarios que son de gran importancia en la cultura sobre la vida y la muerte en las comunidades negras.

En el caso de los y las afrocolombianas del litoral Pacífico que permanecen en sus territorios, una de las causas del desmembramiento de sus culturas consiste en que los actores armados les impiden realizar prácticas culturales primordiales como los ritos fúnebres. Los paramilitares no dejan enterrar ni velar a los muertos, con esto rompen la tradición. Ellos matan a la gente y la tiran al río. Contaminan el agua y el agua del río la usamos para cocinar. Se forman balaceras en los entierros y la gente sale corriendo y dejan el muerto botado. (Mesa de Trabajo "Mujer y Conflicto Armado", 2002, p. 35)

Las mujeres de los pueblos indígenas se expresan sobre el hostigamiento de la justicia indígena al desvirtuarla e impedir su ejercicio. Otro elemento que tiene una implicación directa en las mujeres indígenas es la imposibilidad cultural de sus pueblos de asumir liderazgo, que es 
una labor que ejercen los hombres mayores, lo que les ha impedido organizarse. Esta práctica ha suscitado el cuestionamiento en las comunidades que ven la necesidad de crear una organización indígena paralela de mujeres. Esta búsqueda ha sido reprochada por los cabildos con el argumento de que podría desestructurar la unidad indígena en la organización.

Entre los daños que sufren estos pueblos, el informe destaca el reclutamiento forzado y la utilizaciones de jóvenes y niñas, por tres causas principalmente, el mantenimiento de relaciones afectivas con algún miembro del grupo; la utilización como informantes o mensajeras; y la fuga de mujeres de la justicia tradicional indígena por distintas causas como el embarazo no deseado en una relación pasajera. Otro daño es la persecución a mujeres indígenas por grupos armados, que asesinan a profesoras líderes de las comunidades que aconsejan alejarse de las armas y no sumarse a las filas armadas.

La situación de las mujeres viudas indígenas es un asunto especial, porque en su pueblo se tiene la obligación solidarizarse con las viudas, pero, dado el proceso de desplazamiento y la división política que han sufrido con ocasión de la estigmatización de sus familiares asesinados por grupos armados, sufren el aislamiento y la falta de solidaridad por su pueblo, por el miedo que produce una nueva estigmatización a quienes las ayuden.

Los actores armados acuden a varias estrategias para vincular a sus grupos a mujeres indígenas jóvenes. Algunas de ellas son reclutadas bajo presión, otras se incorporan a partir de sus relaciones afectivas con algún miembro del grupo, otras son utilizadas como informantes, mensajeras y para tareas de observación. Se van con ellos por amor, por el uniforme, por interés. Porque tienen problemas con un vecino y le quieren dar miedo. También por huir de las autoridades tradicionales que les han impuesto algún castigo. Muchas veces, cuando una joven sale en embarazo de una relación pasajera o del novio, ella sabe que la van a castigar, le da miedo y se va con los armados.39 Muchas veces son las muchachas las que llevan la información a la guerrilla o a los paras y las que les avisan cuando vienen los del bando contrario. Esto hace que vayan 
entrando en confianza con los actores armados y por esa vía sucede el reclutamiento. El reclutamiento nos genera dolor y sufrimiento. (Mesa de Trabajo "Mujer y Conflicto Armado", 2002, p. 35)

Con ocasión de la visita de la Comisión Interamericana de Derechos Humanos, en adelante CIDH, se publicó en el año 2006 un informe titulado "Las mujeres frente a la violencia y la discriminación del Conflicto armado en Colombia" en el que se considera que el ejercicio de la violencia contra la mujer es una estrategia de guerra empleada por los actores armados. El informe caracteriza cuatro aspectos: lesionar al enemigo, desplazamiento forzado, violencia sexual y pautas de control social.

En busca de lesionar al enemigo, se documenta la deshumanización de la víctima mediante la agresión a su núcleo familiar y el miedo a la comunidad para afianzar el control social, cuyo efecto es el rechazo y la estigmatización de sus comunidades, familias y parejas. Este tipo de violencia en delitos sexuales en 2004 es del $25.8 \%$ de las cuales el $84 \%$ corresponde a mujeres, para un total de 14369 dictámenes registrados por Medicina Legal.

52. La violencia sexual vulnera de manera especial al bando contrario porque los hombres son considerados tradicionalmente como los protectores de la sexualidad de las mujeres en su comunidad. Por tanto, cuando la sexualidad de las mujeres es abusada y explotada, esta agresión se convierte en un acto de dominación y poder sobre los hombres de la comunidad o el grupo bajo control. La Mesa de Trabajo Mujer y Conflicto Armado ha señalado sobre la violencia contra las mujeres en Colombia que: "El honor de las mujeres está referido al de los hombres y, por esta razón, violar a una mujer en el contexto del conflicto armado se considera una acción contra el honor del enemigo, una forma de venganza." 48 Por tanto, en el contexto del conflicto armado colombiano, la amenaza de violencia, en especial la sexual, es ejercida por los actores armados "como un acto simbólico contra el bando contrario." 49 Asimismo, la Mesa también ha señalado que: "Algunas mujeres han presenciado o saben de violaciones, abusos y chantajes sexuales que son realizados públicamente como actos ejemplarizantes y de retaliación”. (CIDH, 2006, p. 19) 
Del total de personas que han sufrido desplazamiento forzado el $50 \%$ son mujeres, y cuatro de cada diez son mujeres cabezas de hogar, lo que corresponde al $30 \%$ de los desplazados. entre 1995 y el 30 de mayo de 2005 se desplazaron 1.6 millones de personas en Colombia.

El reclutamiento de mujeres y niñas es una práctica que no ha podido ser verificada con exactitud, puesto que en muchos casos el reclutamiento forzado es disfrazado mediante el reclutamiento voluntario cuando los grupos armados enamoran a las mujeres con el fin de llevarlas a ser parte del grupo, en otros casos surge por la promesa de una remuneración y de una protección de seguridad para sus familias, que nunca es cumplida. Y estos son solo algunos casos que ejemplifican esta dificultad.

La imposición de pautas sobre comportamiento en mujeres y niñas surge por el control del territorio que tienen los grupos armados con estereotipos de género arraigados culturalmente, como el machismo y la homofobia, lo que determina normas para el comportamiento y el arreglo personal. Se estigmatiza a las mujeres prostitutas, a las lesbianas, a las mujeres que se vistan de forma insinuante y a las transgéneristas, entre otras.

En el informe de la CIDH se expresa la múltiple discriminación que sufren mujeres afrodescendientes e indígenas, que sufren discriminación desde su nacimiento por su sexo y por el color de su piel, lo que propicia los abusos por los grupos armados. Las mujeres afrodescendientes se expresan como de alta gravedad la pobreza en que viven:

113. El racismo y la marginalización de las poblaciones afrocolombianas, así como el residir en territorios con riquezas atractivas para los actores armados, les ha significado el que sus territorios se conviertan en escenarios de violencia y muerte y sean una de las poblaciones con el nivel de desplazamiento forzado más alto, el cual puede llegar a un $30 \%$ de acuerdo con codhes y a Human Rights Watch. 137 Por ejemplo, a nivel territorial, el Chocó es un territorio atractivo para los actores armados porque posee uno de los mayores niveles de biodiversidad en el mundo, tiene costas en ambos océanos, es propicio para el cultivo de coca y palma aceitera. Para los afrocolombianos, esta situación es particularmente dura 
debido al vínculo estrecho entre su territorio y su cultura, identidad y pasado. Las agresiones de los actores armados son un ataque a su cultura y a su cosmovisión. (CIDH, 2006, p. 43)

El desplazamiento de mujeres que asumen la jefatura del hogar con enfoque étnico representa en afrodescendientes el $47 \%$ y en indígenas el $49 \%$, esta situación ha implicado la pérdida en la práctica de sus culturas y en la falta de unidad como comunidades y pueblos con una propiedad colectiva, una identidad colectiva y la construcción de un proyecto de vida colectivo que termina por desestructurarse por el ejercicio de la violencia.

Sisma Mujer publicó un informe en 2009 titulado "Mujeres en conflicto: violencia sexual y paramilitarismo" donde se expresa el impacto del paramilitarismo sobre la vida y la dignidad de las mujeres por violencia sexual como estrategia de guerra. Allí,se expresa la importancia de la sentencia T-025/04 (2004), en la cual la Corte Constitucional reconoce los derechos de los desplazados en Colombia y el impacto sobre las mujeres. Además, en el Auto 092 (2008) la Corte Constitucional ordena medidas de protección para las mujeres en situación de desplazamiento forzado. Por su parte, la CIDH diagnostica que "La violencia sexual contra la mujer es una práctica habitual, extendida, sistemática e invisible en el contexto del conflicto armado colombiano que permanece casi en total impunidad" (CIDH, 2006, p. 29). Este informe documenta desde 1996 a 2004 las situaciones de violencia sexual que han sido denunciadas y documentadas por esta Organización (tabla 13), y expresa la modalidad de las violaciones a los Derechos Humanos (tabla 14).

Respecto a la violencia realizada sobre mujeres consideradas como colaboradoras o simpatizantes o informantes de la guerrilla, se indica que es una violencia específica con listas en mano que buscan dañar su dignidad con el fin de señalarlas frente a su familia y su comunidad sobre el nexo que tienen con grupos guerrilleros. Esta es una violencia pública con el fin de ejercer control social sobre la población.

Las masacres y la violencia sexual en las prácticas paramilitares desarrolladas entre 1997 y 2003, lapso en el que se determina su desarrollo, se ejerció violencia sexual en 15 masacres y su pico más alto fue el año 2003, cuando se documentaron cerca de 18 casos. 
Tabla 13. Situación de violencia sexual denunciada y documentada

\begin{tabular}{|c|c|}
\hline Año & Personas afectadas \\
\hline 1996 & 1 \\
\hline 1997 & 3 \\
\hline 1998 & 3 \\
\hline 1999 & 1 \\
\hline 2000 & 10 \\
\hline 2001 & 6 \\
\hline 2002 & 14 \\
\hline 2003 & 18 \\
\hline 2004 & 8 \\
\hline 2005 & 5 \\
\hline 2006 & 4 \\
\hline Sin especificar & 24 \\
\hline
\end{tabular}

Fuente: (Sisma Mujer, 2009, pp. 32-33).

Tabla 14. Modalidades de la violencia de casos denunciados y documentados

\begin{tabular}{|l|c|}
\hline \multicolumn{1}{|c|}{ Modalidad de la violencia } & Número de casos \\
\hline Indiscriminada, desagregada y propagada & 38 \\
\hline Masacres & 29 \\
\hline Selectiva & 26 \\
\hline Zonas de ocupación paramilitar & 11 \\
\hline Mujeres señaladas como simpatizantes de guerrilla & 6 \\
\hline Total & 97 \\
\hline
\end{tabular}

Fuente: Sisma Mujer (2009, p. 40). 
Este documento resume el desarrollo de algunas de las masacres registradas en las que se presenta la violencia sexual contra la mujer, la caracterización del territorio y la fuente de información, referencia relevante para analizar el impacto de la violencia por el paramilitarismo sobre la mujer en Colombia, motivo por el cual se retomó esta información respetando los derechos de autor con el fin de publicar este importante registro:

Tabla 15. Masacres en las que se reportaron violaciones sexuales por parte de grupos paramilitares (1997-2003)

\begin{tabular}{|c|c|c|}
\hline Lugar, fechas y hechos & $\begin{array}{c}\text { Ubicación dentro } \\
\text { de la estrategia paramilitar }\end{array}$ & Fuente \\
\hline $\begin{array}{l}\text { El } 2 \text { de febrero de } 1998 \\
\text { en el corregimiento de } \\
\text { San José del municipio } \\
\text { La Ceja (departamento } \\
\text { de Antioquia); grupos } \\
\text { paramilitares ejecutaron } \\
\text { a siete campesinos, } \\
\text { saquearon viviendas y } \\
\text { comercio, y se reportó la } \\
\text { violencia y tortura sexual } \\
\text { de una mujer. }\end{array}$ & $\begin{array}{l}\text { Antioquia tiene un } \\
\text { valor estratégico por sus } \\
\text { condiciones geopolíticas, } \\
\text { sociales, económicas y } \\
\text { ambientales. Su territorio } \\
\text { cuenta con dos cordilleras, } \\
\text { tres ríos importantes y una } \\
\text { desarrollada estructura } \\
\text { vial. Estas características } \\
\text { geoestratégicas, son propicias } \\
\text { para que allí converjan } \\
\text { grupos de guerrilla y } \\
\text { paramilitares, que han hecho } \\
\text { de este departamento una } \\
\text { región con una violencia } \\
\text { intensa durante cuatro } \\
\text { décadas. } \\
\text { La expansión paramilitar } \\
\text { hacia todo el departamento } \\
\text { se registra en dos etapas: } \\
\text { desde 1988 a partir del } \\
\text { Nordeste antioqueño (donde } \\
\text { los grupos paramilitares } \\
\text { tienen su cuna) hacia Urabá } \\
\text { (donde hace presencia el } \\
\text { municipio de Mutatá); } \\
\text { y en } 1997 \text { hacia el nordeste, } \\
\text { occidente y oriente (donde } \\
\text { se encuentra el municipio } \\
\text { de la Ceja). }\end{array}$ & $\begin{array}{l}\text { Banco de Datos } \\
\text { del Cinep } \\
\text { y la Comisión } \\
\text { Colombiana } \\
\text { de Juristas }\end{array}$ \\
\hline
\end{tabular}




\begin{tabular}{|c|c|c|}
\hline Lugar, fechas y hechos & $\begin{array}{l}\text { Ubicación dentro } \\
\text { de la estrategia paramilitar }\end{array}$ & Fuente \\
\hline $\begin{array}{l}\text { El } 23 \text { de febrero } \\
\text { de } 1998 \text { en el municipio de } \\
\text { Mutatá (departamento } \\
\text { de Antioquia); grupos } \\
\text { paramilitares ejecutaron } \\
\text { a seis campesinos, } \\
\text { amenazaron y detuvieron } \\
\text { a otro tanto y ordenaron } \\
\text { desnudos y practicaron } \\
\text { requisas en las partes } \\
\text { íntimas a varias mujeres. }\end{array}$ & & $\begin{array}{l}\text { Banco de Datos } \\
\text { del Cinep }\end{array}$ \\
\hline $\begin{array}{l}\text { El } 9 \text { de enero de } 1999 \text { en } \\
\text { el corregimiento El Tigre } \\
\text { del municipio de la } \\
\text { Hormiga (departamento } \\
\text { de Putumayo); se produjo } \\
\text { una incursión militar } \\
\text { donde al menos } 26 \\
\text { personas fueron ejecutadas, } \\
14 \text { desaparecieron y al } \\
\text { parecer algunas personas } \\
\text { fueron sometidas a } \\
\text { torturas y mutilaciones } \\
\text { de índole sexual. }\end{array}$ & $\begin{array}{l}\text { Putumayo es una región } \\
\text { fronteriza con Ecuador y } \\
\text { Perú (donde cobra fuerza } \\
\text { el tráfico de armas) y alberga } \\
\text { extensos cultivos de coca, } \\
\text { lo que lo hace un lugar } \\
\text { estratégico para los actores } \\
\text { armados. Las masacres } \\
\text { y el Plan Colombia atrajeron } \\
\text { a los grupos paramilitares en } \\
\text { un departamento (sobre todo } \\
\text { en el bajo y medio Putumayo) } \\
\text { que tradicionalmente había } \\
\text { estado bajo el mando de } \\
\text { la guerrilla de las Farc. } \\
\text { A partir de estos hechos, } \\
\text { los paramilitares ganaron } \\
\text { el control en la región. }\end{array}$ & $\begin{array}{l}\text { Amnistía } \\
\text { Internacional }\end{array}$ \\
\hline $\begin{array}{l}\text { Al inicio del año 2002, } \\
\text { grupos paramilitares } \\
\text { efectuaron una incursión } \\
\text { a una comunidad indígena } \\
\text { del municipio de Puerto } \\
\text { Caicedo (Putumayo), } \\
\text { durante esta mataron a } \\
\text { una mujer tras violarla } \\
\text { y mutilarla y también } \\
\text { violaron a su hija de } \\
14 \text { años. }\end{array}$ & & $\begin{array}{l}\text { Amnistía } \\
\text { Internacional }\end{array}$ \\
\hline $\begin{array}{l}\text { El } 21 \text { de agosto de 1999, los } \\
\text { paramilitares llegaron al } \\
\text { corregimiento La Gabarra }\end{array}$ & $\begin{array}{l}\text { El Norte de Santander desde } \\
\text { inicios de la década de los } \\
\text { años ochenta ha registrado }\end{array}$ & $\begin{array}{l}\text { Revista Semana } \\
\text { Banco de datos } \\
\text { de Cinep }\end{array}$ \\
\hline
\end{tabular}




\begin{tabular}{|c|c|c|}
\hline Lugar, fechas y hechos & $\begin{array}{c}\text { Ubicación dentro } \\
\text { de la estrategia paramilitar }\end{array}$ & Fuente \\
\hline $\begin{array}{l}\text { del municipio de Tibú } \\
\text { (Norte de Santander) } \\
\text { donde masacraron } \\
\text { a } 35 \text { personas y } \\
\text { desaparecieron a otro } \\
\text { tanto. La Fiscalía ha } \\
\text { escuchado los testimonios } \\
\text { masivos de violaciones de } \\
\text { mujeres. El } 25 \text { de marzo de } \\
\text { 2001, en el corregimiento } \\
\text { El Guamalito del } \\
\text { municipio El Carmen } \\
\text { (Norte de Santander); } \\
\text { grupos paramilitares } \\
\text { ejecutaron a quince } \\
\text { personas, una de ellas fue } \\
\text { mutilada sexualmente. }\end{array}$ & $\begin{array}{l}\text { una importante presencia } \\
\text { de grupos guerrilleros, } \\
\text { que han buscado usar los } \\
\text { beneficios estratégicos } \\
\text { que concede su ubicación } \\
\text { fronteriza con Venezuela, } \\
\text { su potencial petrolero, la } \\
\text { producción cocalera y los } \\
\text { corredores que comunican } \\
\text { el oriente con el norte del } \\
\text { país. Ante este panorama, } \\
\text { los grupos paramilitares } \\
\text { desde } 1999 \text { han ejercido una } \\
\text { fuerte ofensiva contra este } \\
\text { municipio buscando afectar } \\
\text { la estructura militar de la } \\
\text { guerrilla del ELN y disputar } \\
\text { sus recursos económicos }\end{array}$ & \\
\hline $\begin{array}{l}\text { El } 20 \text { de noviembre de } \\
1998 \text { en el poblado La } \\
\text { Cabuya en el municipio } \\
\text { de Tame (Arauca); grupos } \\
\text { paramilitares asesinaron } \\
\text { a } 4 \text { campesinos. Violaron } \\
\text { y mutilaron a una mujer } \\
\text { embarazada. El } 7 \text { de mayo } \\
\text { de } 2003 \text { en la comunidad } \\
\text { indígena de Flor Amarillo } \\
\text { ubicada en el municipio } \\
\text { de Tame (Arauca); grupos } \\
\text { paramilitares asesinaron a } \\
\text { cuatro indígenas y violaron } \\
\text { a cuatro más. }\end{array}$ & $\begin{array}{l}\text { Arauca es un departamento } \\
\text { relacionado con la economía } \\
\text { del petróleo. La presencia } \\
\text { de grupos guerrilleros y } \\
\text { paramilitares tiene origen en } \\
\text { la violencia vivida en los años } \\
\text { cincuenta. A partir de 1997, } \\
\text { los grupos paramilitares } \\
\text { aumentaron su pie de } \\
\text { fuerza para irrumpir en la } \\
\text { región. Su presencia en el } \\
\text { departamento se encuentra } \\
\text { ligada a las dinámicas } \\
\text { desplegadas por ellos en el } \\
\text { oriente colombiano, sobre } \\
\text { todo en Casanare y Meta, y } \\
\text { a las estructuras aliadas al } \\
\text { narcotráfico y la explotación } \\
\text { de esmeraldas. }\end{array}$ & $\begin{array}{l}\text { Mesa de Trabajo } \\
\text { de Mujer y } \\
\text { Conflicto } \\
\text { Armado }\end{array}$ \\
\hline $\begin{array}{l}\text { El } 31 \text { de agosto de } 2002 \\
\text { en el corregimiento } \\
\text { Tomarrazón del municipio } \\
\text { de Riohacha (Guajira); } \\
\text { grupos paramilitares } \\
\text { asesinaron a } 19 \text { personas, } \\
\text { algunas de ellas fueron }\end{array}$ & $\begin{array}{l}\text { En la Región de la Sierra } \\
\text { Nevada de Santa Marta hay } \\
\text { importantes explotaciones } \\
\text { agropecuarias y se encuentra } \\
\text { bordeada por el oleoducto } \\
\text { que transporta crudo, lo que } \\
\text { la hace una ecorregión }\end{array}$ & $\begin{array}{l}\text { Cinep y la } \\
\text { Oficina de la Alta } \\
\text { Comisionada } \\
\text { para los } \\
\text { Derechos } \\
\text { Humanos } \\
\text { en Colombia }\end{array}$ \\
\hline
\end{tabular}




\begin{tabular}{|c|c|c|}
\hline Lugar, fechas y hechos & $\begin{array}{c}\text { Ubicación dentro } \\
\text { de la estrategia paramilitar }\end{array}$ & Fuente \\
\hline $\begin{array}{l}\text { abusadas sexualmente y } \\
\text { sus cuerpos mutilados. } \\
\text { Durante los días } 18,19 \\
\text { y } 20 \text { de febrero de } 2000 \\
\text { en la vereda El Salado } \\
\text { del municipio Carmen de } \\
\text { Bolívar (Bolívar) un grupo } \\
\text { de paramilitares torturó } \\
\text { y ejecutó a } 46 \text { campesinos } \\
\text { aproximadamente, y } \\
\text { violaron, por los menos } \\
\text { a siete mujeres. }\end{array}$ & $\begin{array}{l}\text { estratégica. Además, es un } \\
\text { refugio para las economías } \\
\text { ilegales de coca, contrabando } \\
\text { y secuestro. Estas condiciones } \\
\text { propician la disputa entre } \\
\text { guerrilla y paramilitares. Para } \\
\text { estos últimos, los ataques } \\
\text { contra la población civil } \\
\text { han sido una característica } \\
\text { de su guerra antisubversiva. } \\
\text { La presencia de paramilitares } \\
\text { es más fuerte en la zona } \\
\text { plana de esta región, donde } \\
\text { se está Riohacha. }\end{array}$ & \\
\hline $\begin{array}{l}\text { Durante los días } 18,19 \\
\text { y } 20 \text { de febrero de } 2000 \\
\text { en la vereda El Salado } \\
\text { del municipio Carmen de } \\
\text { Bolívar (Bolívar) un grupo } \\
\text { de paramilitares torturó y } \\
\text { ejecutó a } 46 \text { campesinos, } \\
\text { y violaron, por los } \\
\text { menos a siete mujeres. } \\
\text { El } 17 \text { de enero de } 2001 \\
\text { en el corregimiento de } \\
\text { Chengue del municipio } \\
\text { de Ovejas (Sucre), se } \\
\text { registró la muerte de } \\
\text { decenas de personas, que } \\
\text { antes de ser ejecutadas } \\
\text { fueron torturadas y varias } \\
\text { mujeres fueron sometidas a } \\
\text { violencia sexual. }\end{array}$ & $\begin{array}{l}\text { El municipio de Ovejas, } \\
\text { Carmen de Bolívar y San } \\
\text { Benito Abad forman parte } \\
\text { importante de la región } \\
\text { conocida como Montes } \\
\text { de María y sus entornos. } \\
\text { Es un corredor estratégico } \\
\text { para transportar armas y } \\
\text { drogas y escondite clave de } \\
\text { guerrilleros y paramilitares. } \\
\text { A comienzos de 1990, } \\
\text { se registra la irrupción de } \\
\text { grupos paramilitares, luego } \\
\text { de la expansión de grupos } \\
\text { guerrilleros hacia zonas } \\
\text { ricas y de mayor interés } \\
\text { político. En medio de la } \\
\text { disputa regional se registran } \\
\text { represalias particularmente } \\
\text { contra campesinos de la } \\
\text { región acusados de auxiliar } \\
\text { a la guerrilla }\end{array}$ & $\begin{array}{l}\text { Relatora } \\
\text { Especial sobre la } \\
\text { Violencia contra } \\
\text { la Mujer de la } \\
\text { ONu, Cinep, la } \\
\text { Mesa de Trabajo } \\
\text { de Mujer y } \\
\text { Confl icto Armado, } \\
\text { la Comisión } \\
\text { Colombiana } \\
\text { de Juristas, } \\
\text { la Oficina de la } \\
\text { Alta Comisionada } \\
\text { para los Derechos } \\
\text { Humanos en } \\
\text { Colombia y } \\
\text { medios de } \\
\text { comunicación. }\end{array}$ \\
\hline $\begin{array}{l}\text { El } 23 \text { de agosto de } \\
2002 \text { en el municipio } \\
\text { de San Benito Abad } \\
\text { (Sucre) } 60 \text { paramilitares } \\
\text { incursionaron, intimidaron } \\
\text { a los pobladores, saquearon } \\
\text { tiendas y viviendas y } \\
\text { violaron a cuatro mujeres } \\
\text { en presencia de sus hijos. }\end{array}$ & & $\begin{array}{l}\text { Amnistía } \\
\text { Internacional }\end{array}$ \\
\hline
\end{tabular}




\begin{tabular}{|c|c|c|}
\hline Lugar, fechas y hechos & $\begin{array}{c}\text { Ubicación dentro } \\
\text { de la estrategia paramilitar }\end{array}$ & Fuente \\
\hline $\begin{array}{l}\text { Del } 10 \text { al } 13 \text { de abril de } \\
2001 \text {, en la región Alto Naya } \\
\text { del municipio de Buenos } \\
\text { Aires (Cauca) paramilitares } \\
\text { torturaron y mataron con } \\
\text { motosierras al menos a } \\
\text { veinte personas, y violaron } \\
\text { a algunas mujeres antes de } \\
\text { matarlas } 4 \text { de septiembre } \\
\text { de } 2000 \text { en el municipio de } \\
\text { Buenos Aires (Cauca) los } \\
\text { paramilitares ejecutaron } \\
\text { a cuatro personas, } \\
\text { desaparecieron otras } \\
\text { treinta, y violaron a varias } \\
\text { mujeres. El } 27 \text { de agosto } \\
\text { de } 2001 \text {, en la inspección } \\
\text { de Policía Yurumanguí del } \\
\text { municipio de Buenaventura } \\
\text { (Valle del Cauca); } \\
\text { paramilitares ejecutaron a } \\
7 \text { personas, hirieron a dos, } \\
\text { quemaron dos guarderías } \\
\text { infantiles y una vivienda } \\
\text { y violaron a una mujer, } \\
\text { causando el desplazamiento } \\
\text { forzado de los pobladores. }\end{array}$ & $\begin{array}{l}\text { A partir del año } 2000, \\
\text { se asentaron grupos } \\
\text { paramilitares en Buenaventura } \\
\text { y en la parte plana del } \\
\text { Valle, donde se encuentra } \\
\text { el municipio de Buenos } \\
\text { Aires. El interés estratégico } \\
\text { de esta región reside en la } \\
\text { explotación de narcóticos y } \\
\text { en que garantiza vías para la } \\
\text { exportación de droga a través } \\
\text { del río Naya, en este caso a } \\
\text { los paramilitares del Bloque } \\
\text { Calima. }\end{array}$ & $\begin{array}{l}\text { Amnistía } \\
\text { Internacional, } \\
\text { Banco de datos } \\
\text { del Cinep y } \\
\text { la Comisión } \\
\text { Colombiana } \\
\text { de Juristas }\end{array}$ \\
\hline $\begin{array}{l}\text { El } 18 \text { de mayo de } 2002 \text { en } \\
\text { Yondó, Casabe (Antioquia) } \\
\text { cerca de } 100 \text { paramilitares } \\
\text { además de ejecutar a quince } \\
\text { campesinos, violaron a una } \\
\text { mujer. }\end{array}$ & $\begin{array}{l}\text { La lucha por los cultivos de } \\
\text { coca en los municipios del } \\
\text { sur del Bolívar (San Pablo, } \\
\text { Simití y Cantagallo) y el } \\
\text { municipio de Yondó, todos en } \\
\text { el Magdalena Medio, explican } \\
\text { la confrontación y presencia } \\
\text { de los actores armados. } \\
\text { A lo anterior se suma la } \\
\text { ubicación de una serranía que } \\
\text { permite la incursión a otros } \\
\text { departamentos con economía } \\
\text { agroindustrial y ganadera. } \\
\text { Ante este panorama los grupos } \\
\text { paramilitares han intentado } \\
\text { conquistar el área desde } \\
\text { 1997 con atentados contra la } \\
\text { población civil. }\end{array}$ & $\begin{array}{l}\text { Banco de Datos } \\
\text { del Cinep }\end{array}$ \\
\hline
\end{tabular}

Fuente: Sisma Mujer (2009, pp. 48-52). 
La finalidad de este tipo de violencia contra la mujer es la subordinación y el daño al entorno social, dado que el ejercicio es público, pues la población es obligada ser espectadora. Con ello, se intimida la población y se desestructura el territorio. Así mismo, conviene destacar que en la mayoría de las masacres se buscó dividir y clasificar a la población víctima de acuerdo con su sexo, para ejercer un tipo de violencia específica, siendo mayoritaria y concurrente la violencia sexual contra las mujeres.

La violencia sexual selectiva, conforme a las identidades sociales, hereditarias, culturales del concepto de mujer, fueron las formas de vestir y de comportarse, para establecer reglas de control social de la población mediante amenazas, panfletos y abusos sobre las mujeres prostitutas, las lesbianas, las mujeres infieles y las formas no recatadas de vestir. También se documenta en este informe la violencia sexual sobre la prostitución y la esclavitud sexual ejercida sobre las zonas de ocupación paramilitar, donde la justificación que argumentaron los actores era el rol de la mujer y el sentido de existencia determinados por la satisfacción de las necesidades masculinas.

Los relatos coinciden en señalar que en dichas regiones se justificó la violencia sexual contra la mujer en su modalidad de prostitución forzada y esclavitud sexual, como una práctica social naturalizada encaminada a satisfacer las "necesidades masculinas", y que incluso altos miembros de los bloques paramilitares alentaron y organizaron tales hechos. Esto permite distinguir una vez más la aparición de un modelo de feminidad particular en el proyecto paramilitar, que considera a la mujer como un objeto sexual disponible; sumado a la idea de la sexualidad masculina como algo que no puede ser contenido, y que por el contrario debe ser siempre objeto de satisfacción por parte del género femenino. Un relato en donde se reportó la violación como forma de violencia sexual pone de presente esta situación: "Luego me dijo que me vistiera y también dijo: "Aquí no pasó nada. Las mujeres, al fin y al cabo son para esto”. (Sisma Mujer, 2009, p. 78)

Finalmente, la violencia sexual indiscriminada, desagregada y propagada en todo el territorio nacional ocurre especialmene en Antioquia, 
en la ciudad de Medellín y en Barrancabermeja, que son los territorios de mayor control donde se permitió el despliegue generalizado del paramilitarismo en Colombia.

El 16 de mayo de 2012, Sisma Mujer divulgó el informe sobre "El Estado y la violencia sexual contra las mujeres en el marco de la violencia sociopolítica en Colombia". En este informe, se documenta el avance legislativo enfocado a apoyar y proteger a la mujer en el contexto de la violencia y la reparación como víctimas directas del conflicto. La insuficiencia de inversión económica para desarrollar estos programas ha impedido su ejecución, lo que lleva a generalizar la impunidad de este tipo de violencia. Sobresale el desarrollo de ataques contra defensores de derechos humanos por grupos paramilitares supuestamente desmovilizados, como es el caso de Águilas Negras y Rastrojos, respecto a los que se registra en 2009 un total de 9 panfletos de amenaza a 93 mujeres y 12 organizaciones de mujeres víctimas del desplazamiento.

El 23 de diciembre de 2010 organizaciones de mujeres, feministas, de mujeres y otras de derechos humanos denunciaron las amenazas de muerte contra cuatro defensoras de los derechos humanos de los departamentos de Cauca y Valle del Cauca realizadas por grupos paramilitares a través de las Águilas Negras Nueva Generación. Las más recientes amenazas recibidas el 7 de mayo de este año están dirigidas a organizaciones de mujeres y de derechos humanos entre ellas la mayoría de las que suscribimos este informe, y a personas individuales. El texto que acompaña al último panfleto por parte de quienes se autodenominan "rastrojos" advierte: "Cada uno de los miembros y dirigentes de estas "o.n.g” son declarados hoy 7 de mayo de 2012 son declarados (sic) objetivos militares. No importa edad, ni género, ni raza, ya empezamos con los líderes indígenas que reclaman lo que no debe (sic)".Ese mismo día, tres días antes del sexto aniversario de la sentencia que despenalizó el aborto en tres circunstancias en el país, un proyectil penetró el vidrio de seguridad de las oficinas de Women's Link Worldwide, una de las organizaciones que lidera la defensa del derecho de las mujeres a interrumpir su embarazo. (Sisma Mujer, 2012, p. 7) 
De 2001 a 2009, prevalece la violencia sexual contra la mujer ejercida por la fuerza pública en un total de 407 municipios, para un total de 489687 casos de violencia directa. El homicidio de mujeres, según las cifras que registró Medicina Legal, fue de 57530 casos, de los cuales 304 fueron actores armados y de estos el $79.9 \%$ de las Fuerzas Militares, 4.9 \% Farc, $4.3 \%$ ELN 3.9 \% Policía, $2.3 \%$ Bacrim. Entre 2008 y 2010, se registraron 52681 informes periciales sexológicos por la presunta comisión de delitos sexuales, de los cuales 219 los responsables directos fueron actores armados.

El informe señala los efectos de la explotación minera contra la mujer, puesto que la mayoría de los trabajadores son hombres y están protegidos o tienen nexos con los paramilitares, lo que propicia la violencia sexual contra las mujeres que se encuentran en estos territorios.

Se rescata el avance constitucional en materia de aborto en 2006, pues uno de los tres casos se trata de violencia sexual, pero su práctica sigue careciendo según las entidades de salud, lo que sigue expresando la constante sobre la tercera causa de mortalidad femenina en los abortos ilegales. De acuerdo con las cifras oficiales, se realizaron 1102 abortos legales en 2012 de los cuales el $26 \%$ fueron de embarazos por violencia sexual.

Este informe expresa la impunidad de la violencia sexual en Colombia con la expedición de la Ley 975 de 2005, Ley de Justicia y paz, bajo cuyo respaldo, en 42 casos se confesaron delitos sexuales, y solamente en 24 de estos se registra la autoría de quien confiesa el delito, por lo cual esta Organización indica la necesidad de adoptar un enfoque diferencial en la Administración de Justicia que dignifique la atención de las mujeres víctimas y que permita la práctica de la justicia.

En 2015, se registra el informe de la Mesa de Trabajo "Mujer y Conflicto armado" donde se documenta la alarmante situación de violencia sexual contra niñas, niños y mujeres indígenas en el Putumayo, por la ubicación territorial, la explotación de los recursos minero-energéticos, el aumento de la militarización, el narcotráfico, las economías ilegales y el conflicto armado.

Las características de esta violencia son el miedo, el silencio y la falta de denuncia por las víctimas, puesto que dada su identidad étnica, les produce miedo a ser rechazadas por su comunidad, lo que dificulta 
reconstruir los hechos. En algunos casos, se presenta por la falta de comprensión de lo ocurrido, dada la minoría de edad, la falta de educación y la insuficiencia de información sobre la ilegalidad de lo ocurrido.

Teniendo en cuenta esta situación, Casa Amazonía llevó a cabo la aplicación de una línea de base en el 2013, de cuyos resultados resaltamos a continuación los más relevantes a la violencia sexual que reportaron las niñas, los niños y adolescentes (NNA) de instituciones educativas rurales de la zona de frontera con Ecuador. El $7.5 \%$ del total de NNA encuestados ha reconocido que han sido víctimas de algún tipo de violencia sexual. 2 Se registraron " 41 casos de niñas y niños abusados sexualmente, es decir un $10.3 \%$, seguido de un $4.8 \%$ (19) que no respondieron a la pregunta". De estos 41 niños y niñas víctimas de violencia sexual, la mayoría identifican a su agresor, lo que corrobora que son personas conocidas por la familia o incluso son miembros de la misma. En los 26 casos (22 en niñas y mujeres adolescentes y 4 en niños) en que las víctimas lo comentaron, lo hicieron a algún familiar, mientras que en ningún caso se refirieron a instituciones garantes de derechos. En general, el nivel de denuncia es muy bajo, debido al temor por amenazas y represalias, y a la poca credibilidad en las instituciones del Estado frente a esta problemática. Los NNA manifiestan la falta de figuras de confianza al interior de los núcleos familiares, lo que los lleva a guardar silencio. Asimismo, identificaron como el principal agresor al padre, seguido de un vecino o amigo, un desconocido, actor armado, otro familiar, ratificando como factor de riesgo importante para la ocurrencia de la violencia sexual a sus familias y a los hombres como principales agresores. La edad promedio encontrada para el inicio de la vida sexual es de 13 años. Edad de muchísima vulnerabilidad si tenemos en cuenta las condiciones emocionales propias del contexto en el que viven. Es posible inferir que, en la mayoría de los casos, el inicio de la vida sexual está relacionado con situaciones de abuso y violencia sexual. (Mesa de Trabajo "Mujer y Conflicto Armado", 2015, pp. 20-21) 
Entre 2011 y 2013, se registraron en Medicina Legal 64842 exámenes por delitos sexuales, que corresponden al $84.20 \%$ de mujeres y $15.8 \%$ de varones, de los cuales 279 casos tuvieron por lo menos un actor armado responsable. A estas cifras se agrega la insuficiente garantía del Estado en la atención y el acompañamiento a la mujer víctima del conflicto armado. Es posible concluir que la afectación a la mujer en Colombia entre 2000 y 2015 ha estado caracterizada por la violencia sexual como estrategia de guerra por todos los actores armados, el alto índice de homicidios, desplazamiento forzado, aumento de roles sociales (productivos, liderazgo social familiar y cultural) en el restablecimiento del proyecto de vida de su familia y su comunidad. También aparece como un grave problema el reclutamiento forzado y voluntario, la prostitución, la esclavitud doméstica, la persecución y la estigmatización de mujeres líderes de organizaciones sociales, la determinación de normas de conducta, de moral, de forma de vestir, del tipo de relaciones afectivas y sociales que deban tener las mujeres y la ocurrencia de masacres en las que el cuerpo de la mujer es señalado, clasificado, torturado, violado y masacrado, lo que muestra claramente la misoginia de los grupos armados. Lo más grave es el alto grado de impunidad y el inadecuado tratamiento con enfoque diferencial que se le da a la mujer en la atención de las denuncias y el seguimiento de las situaciones y casos sujetos a investigación judicial. Estos elementos serán a analizados a continuación en la intervención de organizaciones y movimientos sociales en los Foros de Participación de los puntos de negociación del acuerdo de paz, con el fin de determinar si estos elementos se reflejaron en las solicitudes y en la construcción del documento final de acuerdo entre las Farc-EP y el Estado Colombiano.

\section{Los movimientos feministas en los foros de política de desarrollo agrario integral y de participación política}

El primer foro de Participación Ciudadana se llevó a cabo durante los días 17, 18 y 19 de noviembre de 2012. En este foro, el objeto de análisis fue el primer punto del acuerdo: El desarrollo agrario integral, según el enfoque territorial. En las propuestas que se plantearon se destaca la búsqueda de un acceso preferente a la tierra por las mujeres y la posibilidad 
del reconocimiento de su titularidad. Se busca la creación del acceso a la tierra con enfoque diferencial para mujeres desplazadas y para las que no sufrieron desplazamiento. En materia de cultivos de coca, se buscó que la situación de las mujeres pudiera empeorar respecto a la justicia y a la posibilidad aportar al desarrollo rural en el escenario publico para la restauración de los derechos de la mujer. Se propuso la creación de un observatorio de la mujer y de la familia que articulara estas funciones. De manera especial, se propuso la protección reforzada a la mujer afrodescendiente, por los efectos del conflicto y que se le reconozca como "dadora de vida" (Universidad Nacional, 2012, p. 152).

El segundo Foro de Participación Ciudadana se desarrolló del 28 al 30 de abril de 2013. En este se reflexionó sobre el segundo punto del acuerdo: Participación Política. Se buscó ampliar la participación de las mujeres, para que al menos fueran el $50 \%$, lo que se reflejó en la cifra con un total de 80 organizaciones de mujeres, para un total de participantes de 1245 personas, de las cuales 139 fueron personas en representación de las organizaciones de mujeres.

En las relatorías, se destaca la ponencia de "Mujeres por la Paz", en la que Olga Amparo Sánchez asumió la vocería para reflexionar sobre la notoria presencia de las mujeres en el evento, como resultado de la lucha histórica que han tenido y que tienen aún en el momento del Foro, puesto que, para poder participar en este, tuvieron que superar obstáculos, dejar a sus familias y sus parejas, y todo lo que esto implica para viajar y estar allí participando, en la esfera pública, un espacio de apertura política y de liderazgo que responde a la reivindicación social que ha logrado.

La reflexión resalta la necesidad de constituir una resistencia al patriarcado y al paramilitarismo, que tanto las ha impactado respecto a sus derechos, por lo cual es necesario buscar una radicalización de la democracia que les permita a las mujeres participar efectivamente en las decisiones sobre el futuro del país:

Implementar y fortalecer medidas para erradicar la violencia y la discriminación contra la mujer, exacerbada por el conflicto armado. Erradicar los factores que ponen a las mujeres en situación de vulnerabilidad. (Universidad Nacional, 2012, p. 78) 
En la relatoría 1: Derechos y garantías para el ejercicio de la oposición política en general, y en particular para los nuevos movimientos que surjan luego de la firma del acuerdo. Acceso a medios de comunicación, se buscó incluir a las mujeres con el respeto y el reconocimiento de la diferencia en la participación política que expresa la Ley estatutaria de garantías de oposición y participación en la actividad política, asumiendo un enfoque territorial y poblacional, otorgando condiciones de igualdad, equidad y participación política de las mujeres en movimientos y partidos políticos. En la relatoría 2: Mecanismos democráticos de participación ciudadana, se incluyen los de participación directa, en todos los niveles y temas, sobre lo cual se insistió en la necesidad de buscar "mecanismos de participación activa, decisoria u directa de las mujeres con enfoques diferenciados" (Universidad Nacional, 2012, p. 56). Este elemento es reiterado en la relatoría 3: medidas efectivas para promover mayor participación en la politica nacional, regional $y$ local de todos los sectores, en las que se incluye la población más vulnerable, en igualdad de condiciones y con garantías de seguridad.

\section{Movimiento social por la diversidad sexual en Colombia}

\section{Breve historia del Movimiento social por la diversidad sexual en Colombia}

La construcción del Movimiento social por la libertad sexual estuvo ligada a la transformación social desarrollados en el contexto de Mayo del 68, cuando los estudiantes universitarios plantearon la transformación estructural y cultural de la sociedad por fuera del discurso marxista, dadas las dinámicas del poder y las nuevas necesidades de enfrentar el desarrollo de la violencia cultural. En este marco de referencia, se adelantó la reflexión sobre la defensa de las libertades sexuales, motivo por el cual se ubica cronológicamente en este mismo año la creación de la primera Organización homosexual "Nuestro Mundo" en Argentina, con pretensiones políticas. Sin embargo, un hecho detonador del desarrollo del movimiento LGBTI, fueron los sucesos ocurridos en el Bar Stonewall en Nueva York, puesto que con los disturbios 
desatados entre la policía y la población homosexual que se encontraba en este lugar es un punto de partida político para el activismo del movimiento del "Gay Power", como punto originario del movimiento.

En Colombia, la narración del Colectivo León Zuleta ubica el origen del movimiento en 1940, con la Organización "Los Felipitos". Sin embargo, la fecha en la que se concreta el origen del Movimiento Gay en Colombia es 1976, con la presencia de líderes como Manuel Velandia, León Zuleta y Guillermo Cortés, entre otros. Esta fecha tiene como antecedentes la labor de APA (Asociación Americana de Psicología), en la supresión de la homosexualidad de la lista de enfermedades mentales en 1973, junto con la primera Conferencia mundial de derechos LGBTI en 1974 en Edimburgo. En 1978, se usa por primera vez la bandera Arco Iris, cuyo creador fue el francés Gilbert Bakon.

El movimiento gay en Colombia, para el año de 1977 se forja como un grupo de estudio semanal, denominado "Grupo de encuentro para la liberación de los "Güeis" (GELG), quienes se reunieron en la biblioteca Emmanuel Mounnier, lo que generó su expulsión, ubicando un nuevo lugar de encuentro en el Parque Nacional de Bogotá, hecho significativo para la destrucción del grupos. No obstante, el 28 de junio de 1979 se documenta la celebración del "Día Gay Internacional”, fecha en la que Manuel Velandia lanza el "Manifiesto por los derechos de los Gay en Colombia":

Liberación, liberación ¿Para qué?

Junio de 1979

¿Un movimiento de liberación homosexual? ¿Para qué? ¡Sí yo ya estoy liberado!

Esta y muchas otras respuestas afines salen a flote en buses, calles, cines, tiendas, bares, cuando se pretende hablar de la emancipación gay.

Liberarse no es la posibilidad de poder: en un bar, cine, o cualquier lugar a puerta cerrada: hacer, decir, una u otra cosa...

Nuestra liberación consiste en conquistar gran cantidad de reivindicaciones, en ser aceptados socialmente en nuestra real identidad: seres normales, aun cuando no respondamos a la normalidad estipulada por los celosos celadores del orden dado, en una 
sociedad, que pretende encarrilar castrando cualesquier posibilidad que atente contra sus "principios morales”, puestos para salvaguardar el "orden natural” que nos aliena sexual y políticamente.

Debemos explorar nuestra sexualidad, disfrutarla y expresar públicamente nuestro deseo, en el mismo lenguaje usado para expresar el deseo de comer, dormir, etc., además el redescubrimiento y la desgenitalización del placer, posibles, mediante la desinstitucionalización de nuestras zonas erógenas y del cambio de los procesos educativos que nos limitan mentalmente y nos sitúan al margen, al dar a conocer únicamente la función procreadora del sexo desechando por "nocivas" todas las demás posibilidades.

Igualmente debemos cuestionar a la familia que en su desarrollo ideológico nos programa para desempeñar roles preestablecidos y a la religión que identifica el placer con pecado, potenciando complejos de culpa que transforman en inadmisible el goce total.

La posibilidad de mostrar con orgullo nuestro Ser Homosexual conlleva: negarse a ser el complemento de la mujer o del hombre para ser nosotros mismos; conquistar nuestra integridad pasando de ser objetos sexuales frente a los "otros " y frente a nosotros mismos; crear las condiciones para ser considerados algo más que un elemento productivo; lograr mecanismos de proyección social y un total despliegue en las demás esferas de la realidad.

Teniendo en cuenta que nuestra lucha no es contra el otro sexo, o marcando las diferencias con las demás minorías sexuales, sino hombro a hombro, mujeres y hombres, juntó con las demás minorías oprimidas y/o reprimidas de una u otra forma.

Aunque muy dentro nos sintamos igual que cualquiera; aun cuando tengamos la capacidad de gozar y manifestar libremente nuestro afecto a otra persona con nuestro mismo sexo; aun cuando vivamos la ilusión de la seguridad estando dentro del bar, apartamento, cine, sabemos muy bien que la práctica de nuestra sexualidad está condenada socialmente a desarrollarse solo en aquellos lugares destinados para tal efecto: el ghetto Guëi.

Si usted desea salir del ghetto puede comunicarse con nosotros, somos un grupo al que usted está invitado y del que usted debe hacer parte. (Velandia, 1979) 
En 1981, se produce el descubrimiento del SIDA como enfermedad de transmisión sexual, lo que implica un trato peyorativo en su nominación, conocida como Afección Gay, la Peste Rosa, entre otros, lo que propicia la discriminación. En Colombia, en esta década, se desarrolla en contexto de abuso policial desarrollado de manera paralela a los procesos de conflicto interno en el país, pero a diferencia de los otros Movimientos Sociales que se vieron afectados por políticas del expresidente Turbay Ayala, como fue el Estatuto de Seguridad Nacional, el Movimiento social por la diversidad sexual en Colombia obtuvo una respuesta diferente del presidente, dada su ideología política liberal favoreció a esta población, mediante el Código Penal de 1980 (Decreto Ley 100 de 1980) en el que se excluyó la homosexualidad de la lista de delitos.

Cabe recordar que hasta 1980 la homosexualidad masculina era un delito y se castigaba con cárcel. Para entonces, sentirse atraído por una persona del mismo sexo era un crimen. Con estas condiciones, las parejas y los individuos de esta orientación sexual tenían que vivir una vida paralela, que se adecuara a lo que era calificado como "normal” y, sobre todo, "legal”. (Rojas, 2012, s p.)

En 1984, en la celebración del Primero de Mayo participó el Movimiento LGBT con la marcha de trabajadores homosexuales. Este periodo de organización y reivindicación de los derechos por la diversidad sexual, fue acompañado de persecuciones violentas, documentadas por Jairo Alberto Marín, en los Estados Unidos, donde, según Manuel Antonio Velandia (2011), denunciaba los crímenes. En 1996, la OMs por primera vez elimina la homosexualidad de la lista de las enfermedades mentales. Solo en 1997 se creó el primer grupo de mujeres lesbianas, denominado Triángulo negro y, posteriormente, en 1999, se incluyeron bisexuales. Y a finales de este periodo aparecen Movimientos Transgeneristas, ligados al trabajo terapéutico realizado por Mariana Trina.

El cambio constitucional de 1991 permitió institucionalizar el Estado Laico, reconocer la igualdad, la prohibición de la discriminación, la creación de la Corte Constitucional y de la Defensoría del Pueblo (instituciones que hasta la fecha actual se han convertido en las principales defensoras de los derechos de la población LGBT en Colombia), instituyó el Derecho al libre desarrollo de la personalidad, lo que propició 
un escenario de protección jurídica amplia en favor del Movimiento. No obstante, en 1993 León Zuleta, uno de los líderes más importantes del Movimiento LGBT, fue asesinado.

Un 23 de agosto de 1993 la sórdida mañana del barrio Loreto de Medellín, después de una convulsionada noche de ruido y rumba, dejaba constancia de otra víctima de homicidio en una ciudad que en ese entonces estaba en la cumbre de la violencia. En este caso la víctima era un hombre que sumaba la inteligencia de la filosofía, el empeño del cambio de la realidad del movimiento sindical y la ilusión de que la sociedad sería verdaderamente un espacio de igualdad: se trataba de León Benhur Zuleta Ruíz, fundador junto con Manuel Velandia del movimiento LGBT colombiano, quien ese día encontró la muerte en su propia casa, a manos de una personas que horas antes lo contactó en un lugar de divertimento de la ciudad y luego lo acompañó hasta su casa, donde le propinó múltiples impactos de arma blanca hasta dejarlo sin Vida. (Caribe Afirmativo, s. f.)

En la década de los noventa, se destacan organizaciones como Colombia Diversa, Mujeres al Borde, Planeta Paz, que contribuyeron al desarrollo jurídico sobre el tema, como la sentencia C-811 de 2007 que amplió la protección de la salud a las parejas homosexuales, la sentencia C-336/08 que aprobó el derecho a la pensión de sobrevivientes en parejas homosexuales, la sentencia C-798/08 que extendió la obligación de alimentos a las parejas homosexuales, la sentencia C-029/09 que reconoce la Unión Marital de Hecho a las parejas del mismo sexo, y la sentencia C-577/11 que les reconoció el derecho a formar una familia.

No obstante el reconocimiento jurídico de la Corte Constitucional, en la práctica social y cultural, los procesos de discriminación se mantuvieron, sobre lo que la Organización Colombia Diversa ha documentado el proceso de violencia contra la población LGBTI, respecto a la Violencia por Prejuicio, la limpieza social y la tortura, el desplazamiento por la Policía, los grupos armados, como ocurre en el paramilitarismo, y varios agentes en las cárceles, y la falta de adecuación de los Derechos Económicos Sociales y Culturales a enfoques diferenciales, continuando los procesos de vulnerabilidad y 
marginalidad de esta población. En los informes, se documenta la violencia ocasionada entre 2005 y 2014.

\section{Impacto del conflicto armado en el Movimiento social por la diversidad sexual}

Colombia Diversa en el Informe 2005 documenta la violencia del periodo 2014-2015 que ha consistido en el asesinato sistemático, denominada como violencia por intolerancia, comprendida como la brutalidad que se comete contra grupos no deseados por la sociedad (2005), la cual es comúnmente conocida como limpieza social: "Las personas LGBT se encuentran en condiciones de vulnerabilidad debido a los prejuicios y a la discriminación histórica, lo cual exige una protección especial por parte del Estado a fin de buscar el equilibrio y la igualdad efectiva con el resto de la población" (Colombia Diversa, 2005). Este tipo de asesinatos suelen contener en común que aparentan ser asesinatos por pasión, dado que se encuentra a la víctima desnuda total o parcialmente, comprobando que previamente a su muerte ha tenido relaciones sexuales, lo que se considera en la investigación judicial como un crímen pasional, y se impide así una documentación sobre este tipo de violencia. Igualmente, ocurre cuando se documenta la agresión como si se tratara de robos callejeros, y se oculta el sentido del ataque, de modo que las mayores dificultades ocurren al determinar la violencia por prejuicio. Esto es claro en la entrevista a Andrés Rodríguez, médico forense del Instituto Nacional de Medicina Legal, en entrevista concedida a Colombia Diversa el 23 de febrero de 2006, en la que cuenta:

Me han dicho: "Doctor, ¿cuál es su interés en averiguar sobre estos homosexuales si finalmente a ellos los matan porque se lo merecen, los matan por maricas?”. (Colombia Diversa, 2006)

En el informe se destacan en Bogotá 60 casos de asesinatos contra homosexuales cuya causa principal es su identidad sexual enre 2000 y 2005, la cifra no permite determinar la magnitud del problema, como consecuencia de la mala clasificación sobre los crímenes. En la violencia que se narra, se destacan los casos más graves en materia de violación 
de derechos humanos, como sucede con una desaparición forzada por grupos paramilitares como "limpieza social":

En Barrancabermeja, paramilitares del Bloque Central Bolívar de las Autodefensas Unidas de Colombia (AUC) desaparecieron forzadamente a Ignacio Eugenio, durante hechos ocurridos en el barrio Palmira. Según la denuncia, "Aproximadamente a la 1:00 a.m. llegaron cuatro tipos encapuchados y armados a bordo de un taxi a tocar a la residencia de Ignacio Eugenio Ariza López, quien convive con su familia. Los hombres tocaron la puerta e Ignacio se paró a abrir. Aquellos hombres preguntaron por su hermano menor Iván Darío Ariza López, quien es homosexual y a quien además los paramilitares habían amenazado de muerte el año anterior por su condición sexual. Los paramilitares, al saber que su víctima no se encontraba, ya que había salido de la ciudad para preservar su vida ante las constantes amenazas, tomaron la opción de llevarse a su hermano, también homosexual, bajo el supuesto que necesitaban hablar con él. El vehículo arrancó y nada se ha sabido de Ignacio Eugenio". (Colombia Diversa, 2005)

El ejercicio de violencia en las Fuerzas Militares, también se documenta, en el discurso de la hombría, junto con el rechazo a conductas femeninas por militares de alto rango al momento de descubrir homosexuales o en situaciones en las que los heterosexuales incumplen alguna actividad militar, un ejemplo es el siguiente caso:

La "homosexualización" del enemigo o del vencido como una forma de ofensa y degradación de su "hombría" es una conducta repetida, que va desde el tratamiento público en los discursos hasta castigos aberrantes cometidos por los mismos instructores contra sus propios soldados, como sucedió en los hechos del 25 de enero de 2006, cuando varios soldados fueron torturados y sometidos a abusos por sus superiores como castigo por haber fallado en una prueba. Una de las formas de tortura consistió en practicarles actos de abuso sexual. La frase que se repitió en el lugar de los hechos para las víctimas de los vejámenes fue: "Lo vamos a violar, marica, lo vamos a violar”. (Colombia Diversa, 2005, p. 21) 
En los centros carcelarios también se documenta violencia, actos de tortura y violaciones contra reclusos homosexuales por otros reclusos, debido a la falta de mando y dominio de los guardias de seguridad lo que indica la falta de garantías y de protección hacia los reclusos, según narra una víctima en un estremecedor testimonio de tortura en la cárcel:

Un día me vistieron de mujer, me pusieron un vestido, me maquillaron y me hicieron desfilar por todo el patio; me ponían una tabla en el cuello, que tenía pintado un pene. Todos me pegaban por la cola, hasta dejarla muy roja, me dolía mucho. Todos se reían; a mí al principio me parecía normal, pero después las burlas aumentaron demasiado. Así empezó todo, pero las cosas cada día eran más peor. Después me cogieron todos y me quitaron la ropa, me obligaron a tener sexo, como con veinte en una noche. Por la cola me salía sangre. Yo ya no quería más, pero como estaban armados no podía hacer nada. Como yo dormía en el piso, llegaban a buscarme siempre en la noche. No me dejaban en paz. Yo les decía que no más, pero siempre me obligaban a mamárselo, a todo lo que decía el cacique. En el patio hay un tanque; a veces me obligaban a meterme y hacer cosas que no me gustaban. El agua era muy fría o a veces estaba muy sucia. (Colombia Diversa, 2005, p. 34)

Entre 2006 y 2007, esta violencia se reitera en un total de 67 homicidios cometidos en los mismos contextos enunciados en el periodo anterior; las cifras que expresa este informe se observan en la tabla 16.

Entre las víctimas, se resalta el departamento del Valle del Cauca con ocasión de la fuerte violencia contra Transgeneristas en Cali, donde el asesinato y las señales de tortura y violación en las que se han encontrado los cadáveres, han sido sistemáticos contra esta población.

Quince días después de este delito, "[el] 19 de diciembre en la noche fue herida con arma de fuego Andrea Anguacho, una chica trans de 29 años de edad y trabajadora sexual en la glorieta del barrio Alfonso López (a 100 metros del lugar del asesinato de María Luisa Perea), también lugar de 'parada' de trabajo sexual de las chicas trans. (Colombia Diversa, 2007, p. 31) 
Tabla 16. Homicidios registrados en el periodo 2006-2007

\begin{tabular}{|l|c|}
\hline \multicolumn{1}{|c|}{ Departamento } & Número de víctimas \\
\hline Antioquia & 5 \\
\hline Atlántico & 3 \\
\hline Bolívar & 2 \\
\hline Boyacá & 1 \\
\hline Caldas & 3 \\
\hline Cauca & 2 \\
\hline Cundinamarca & 13 \\
\hline Huila & 1 \\
\hline Meta & 2 \\
\hline Nariño & 1 \\
\hline Norte de Santander & 1 \\
\hline Santander & 3 \\
\hline Quindío & 1 \\
\hline Valle del Cauca & 29 \\
\hline Total & 67 \\
\hline
\end{tabular}

Fuente: Colombia Diversa (2007, p. 21).

En 2009, Colombia Diversa públicó el informe del periodo 20082009 , en el que se relacionan asesinatos contra la comunidad LGBT en Colombia. La cifra entre 2006 y 2007 fue de 99 homicidios, y entre 2008 y 2009 aumentó a 127 homicidios. De estas cifras, se establece que tan solo cuarenta y seis de los crímenes fueron ocasionados bajo el cargo de "violencia por prejuicio", siete fueron por otras causas y los setenta y cuatro casos restantes ocurrieron con violencia excesiva en la muerte de la víctima. Este patrón demuestra la dificultad del sistema estructural en los procesos de investigación, en los que se ocultan las expresiones homofóbicas con muertes por robo o asesinatos por pasión.

Igualmente, en el documento se registra la persecución a defensores de derechos humanos y líderes de la comunidad LGBTI, cuyas muertes continúan impunes. Es el caso de Wanda Fox, Álvaro Miguel Rivera, Fredys Dario Pineda. 
Es crucial que cuando las autoridades investigan este tipo de casos tengan en cuenta que las lesbianas, gay, bisexuales y transgeneristas que trabajan en la defensa de los derechos humanos corren un mayor riesgo de ser atacados por la estigmatización de la que han sido víctimas como defensores y por la discriminación de la que han sido objeto por su orientación sexual o identidad de género. (Colombia diversa, 2009, p. 19)

También se destaca en este informe el desplazamiento forzado contra personas LGBTI, no solo por causa del conflicto interno, sino también por la violencia generalizada y crímenes recurrentes y masivos contra los derechos humanos:

Así las cosas, no solo se ha de tener en cuenta el desplazamiento derivado de los enfrentamientos en el marco del conflicto armado interno, sino también las situaciones de control territorial por parte de actores armados y los desplazamientos relacionados con situaciones de violencia generalizada contra personas LGBT, incluso la violencia institucional, como el abuso policial. (Colombia diversa, 2009, p. 132)

Entre los problemas que resaltan por desplazamiento contra la comunidad LGBT está la falta de documentación y sistematización de las autoridades de estos delitos, en especial en las decisiones de la Corte Constitucional, dado que la protección a la población desplazada se ha realizado una caracterización de la población en condición de discriminación que sufre el desplazamiento. Esto ocurre igualmente en los pueblos indígenas, las comunidades afrodescendientes, las mujeres, los niños y los discapacitados, pero no hay un marco especial de construcción judicial sobre la población LGBT (sentencia T-025/04, Autos: 092/08, 004/09, 006/09 y 218/06). La caracterización que se hace en el informe de Colombia Diversa se puede resumir en las siguientes variables de trato especial:

Al momento del desplazamiento eran niños y no tenían clara su identidad sexual, durante y/o después del desplazamiento esta aparece con claridad circunscrita a la comunidad LGBT. 
Personas adultas que antes del desplazamiento ocultaban su identidad y con el desplazamiento deciden expresarla.

Desplazamiento ocasionado porque los actores armados desarrollan prácticas de control social, que excluyen, rechazan y señalan a los LGBT, por lo que se incrementa el miedo a afirmar la identidad sexual diversa.

Con ocasión de la violencia por intolerancia, mal llamada limpieza social.

Con ocasión de la señalación y estigmatización de su identidad sexual con una identidad criminal, como es el caso de ladrones, violadores y/o expendedores de drogas:

En versión libre colectiva, el frente 'José Pablo Díaz' de las AUC reconoció el crimen de tres travestis en la calle. Según los desmovilizados, el triple crimen de los homosexuales se registró por una orden de 'El Loco Víctor', quien era el comandante del 'sector de la 40', y que el hecho fue cometido a eso de las 11:30 de la noche, porque tenían azotado el pedazo (sic) dándoles burundanga a las víctimas para atracarlas y hurtarles sus pertenencias. Según uno de los versionados, en esos momentos había otros tres homosexuales. (Colombia diversa, 2009, p. 138)

Con ocasión de panfletos que atemorizaban a la comunidad, se documenta en el año 2009, de acuerdo con la Oficina del Alto Comisionado de Naciones Unidas para los Derechos Humanos, los siguientes resultados:

d) Entre febrero y marzo circularon panfletos con amenazas en por lo menos 24 de los 32 departamentos del país. Un formato estándar fue distribuido en poco más de dos semanas, en lugares tan distantes como Armenia, Barranquilla, Bogotá, Chocó, Cúcuta, Medellín y Valle del Cauca. El documento alentaba la mal llamada 'limpieza social' contra trabajadores sexuales, homosexuales, drogadictos y personas viviendo con VIH, entre otros. El panfleto textualmente indicaba que '[quien] se encuentre [...] después de las 10:00 horas 
[en la calle] no responderemos', ordenaba '[...] esté más con la familia' y pedía 'perdón a la sociedad si caen inocentes. (Colombia diversa, 2009, p. 140)

Entre 2010 y 2011, continúan las falencias judiciales respecto a la caracterización de los delitos y violaciones contra las personas LGBT, de tal forma que se impide la construcción de la verdad y la justicia en su comunidad. Se registran abusos policiales, asesinatos a gran escala, y se registra la cifra más alta pues se llega a 280 personas asesinadas pertenecientes a la comunidad LGBT. Antioquia es el departamento con mayor número de homicidios (85), seguido de Valle del Cauca (45) y de Bogotá (25). El informe destaca las cifras de panfletos en el departamento del Atlántico. Uno de cuyos textos en marzo de 2011 en Cúcuta cuyo contenido era el siguiente:

HACEMOS ESTE COMUNICADO A TODOS LOS TRAVESTIS HIJUEPUTAS Y ASUS (SIC) CACORROS Y ALCAHUETAS

DE ESOS HP

ESTE ES UN COMUNICADO PARA TODOS LOS HIJUPUTAS, TRAVESTIS, CACORROS, DROGADICTOS, CALLEJEROS, QUE SE ESTÁN INSTALANDO EN EL SECTOR (SIC) DE LA CALLE 7AV 3 Y A CELADORES QUE NO QUEREMOS VER MAS EN ESTA ZONA.

NADA DE PARCHES DE JOVENES NI LESVIANAS (SIC) FUERA DE LOS NEGOCIOS PORQUE VAMOS A PASAR EN ESTOS DIAS HACER (SIC) LIMPIEZA. SE LES INFORMA A LOS NEGOCIOS QUE NO LES VENDA NADA A ESTAS PERSONAS NI LOS DEJE SENTAR ALAS (SIC) AFUERA (SIC) DE SU NEGOCIO PARA NO TENER QUE PERJUDICARLOS CUANDO FUCILEMOS (SIC) A ESTOS HIJUEPUTAS LA SEÑORA DE LOS PERROS SE TENDRÁ QUE IR POR SER COMPLICE DE LOS HIJUPUTAS Y CORRERA LOS MISMOS DESTINOS (SIC). Y LOS NEGOCIOS DE CAFÉ JACK Y CROMOS. MAS ORDEN A LAS AFUERA (SIC) DE SU NEGOCIO". (Colombia Diversa, 2011, p. 13) 
En síntesis, las principales afectaciones del conflicto armado en Colombia contra la Comunidad LBGTI se documentan los panfletos, como mecanismo de control social sobre una población y un territorio específico, según un canon de masculinidad y feminidad ligado a la condición biológica del nacimiento, y la transgresión e ese canon es merecedora de persecución, tortura, violaciones y desapariciones. Este tipo de prácticas e ideologías se repite en el sistema carcelario, que es el segundo escenario del conflicto armado en Colombia, ligado a los procesos de investigación y a la Ley de Justicia y paz (Ley 975 de 2005), en la que se instauró la justicia transicional en favor del Paramilitarismo en Colombia, también aparece en las fuerzas militares y en la Policía Nacional, donde la feminidad se considera inferior a la masculinidad. Se añade la falta de investigación judicial y de articulación eficaz de un enfoque diferencial que anule los prejuicios, de modo que se combata la violencia por prejuicio, y se realicen investigaciones que permitan demostrar el ejercicio de violencia contra la Comunidad LGBTI, como expresión del conflicto armado, la violencia política, económica y cultural.

\section{Participación del movimiento por la diversidad sexual en los foros de participación ciudadana}

En el primer Foro de Participación ciudadana participaron 1314 ciudadanos entre los cuales se encontraron organizaciones campesinas, empresariales, indígenas, afrodescendientes, de mujeres y jóvenes, defensoras de derechos humanos, de víctimas y desplazados, universidades, partidos políticos, etc. Entre ellas, se incluyeron también organizaciones LGBTI que contribuyeron a reflexionar sobre el enfoque de género, y sobre el empoderamiento de las mujeres en materia de titulación de la tierras. Sin embargo, en la sistematización no se ubicó un apartado sobre los LGBTI, sino sobre el "Acceso a mujeres": Se trata de que el proceso de reforma rural o agraria garantice una perspectiva de género que garantice el derecho de las mujeres a la tierra. Esto permite expresar un elemento ausente en el contenido de este Foro, a pesar de contar con la participación LGBTI. 
De manera diferente, se ubicó un trato diferenciado a la población LGBTI en el segundo Foro de Participación Ciudadana en materia de Participación Política. Allí, se ubicó la importancia de constituir mecanismos que faciliten la participación política en movimiento y partidos políticos de la población LGBTI, donde se propicie la articulación de un enfoque diferencial transversal que otorgue garantías para participar políticamente. Se propuso fomentar la creación de instituciones similares a las casas de participación en las que se puedan reunir los miembros de la comunidad LGBTI, con el fin de poder discutir sus intereses y dar solución a sus problemas.

\section{Movimiento social afrocolombiano}

\section{Breve historia del Movimiento social afrocolombiano}

El movimiento afrodescendiente colombiano ha llegado a ser el marco de la reivindicación por el reconocimiento de la tierra y la diversidad cultural de los pueblos indígenas, tanto porque este ha sido el escenario de reconocimiento de lo étnico y lo cultural en materia de derechos constitucionales, como por la construcción del concepto de mestizaje de la identidad colombiana, con lo cual se elimina la posibilidad de comprender grupos estrictamente afrodescendientes:

En el movimiento social afrocolombiano, la idea de pueblo todavía no se encuentra muy arraigada, la idea predominante es la de comunidad negra, aunque la noción de pueblo afrocolombiano se refiere a todos los colombianos y las colombianas de ascendencia africana, y cuyos antepasados fueron traídos a América a través de la trata trasatlántica. En el derecho internacional, la concepción de pueblo hace referencia a la autodeterminación, en este sentido cuando se habla de Pueblo se hace referencia a Estados. Sin embargo, los pueblos indígenas han logrado que se les llame pueblos a partir de sus ejercicios de autonomía y sus particularidades culturales e históricas, por esta razón son reconocidos, igual que los derechos colectivos que les caracterizan. La declaración de Naciones Unidas sobre pueblos indígenas reconoce 
a estos colectivos como pueblos e insta a su reconocimiento y respeto por parte de los Estados y los organismos internacionales. En la legislación colombiana al pueblo afrocolombiano se le reconocen derechos colectivos y también individuales, y también se le reconoce cierto nivel de autonomía, ligándolos a sus particularidades históricas y culturales. (Wabgou, M., Arocha, Salgado, \& Carabalí, 2012, p. 219)

En los últimos veinte años, ha cobrado fuerza el discurso de los afrodescendientes, de modo que las movilizaciones de comunidades negras se han observado mediante varios enfoques históricos de reivindicación de la descendencia africana, como la lucha contra el Apartheid Sudafricano y las luchas en Estados Unidos durante siglos, la participación política de las Panteras Negras, la figura de Nelson Mandela, la defensa de la identidad bajo el lema "lo negro es bello" y "the black power", entre otros.

En el movimiento afrocolombiano, se rememora la libertad obtenida por Benkos Biohos como un periodo histórico cuando la lucha por la liberación del pueblo negro tuvo una connotación especial. Estudios específicos sobre los afrodescendientes en Colombia se han desarrollado por autores como Jaime Arocha y Manuel Zapata Olivella. Cabe destacar el trabajo de recopilación del movimiento afrodescendiente y raizal realizado por la Universidad Nacional en el que se representa la acción histórica y el sentido de las demandas de los afrodescendientes en Colombia, motivo por el cual se retomarán estos trabajos para determinar el sentido de la defensa por los derechos de las negritudes en Colombia.

El concepto de cimarrón alude a la libertad obtenida durante la época de la esclavitud, de la trata negrera en América y el caribe en el siglo $\mathrm{xv}$, ya que es desde entonces cuando llegan los afrodescendientes al continente americano. Zapata Olivella recuerda esta llegada en su obra "Changó, el gran putas", al narrar el origen de la llegada a América, donde se castigaron los Afro por la rebelión contra Changó y su posterior maldición, pero también es la tierra de la libertad, que será obtenida mediante la promesa del mestizaje. 
He visto la tierra que parió Odumare.

¡América!

La olvidada tierra donde Olofi dejó su huella

piel leopardo.

¡Esa tierra olvidada por el Muntu

espera

espera

hambrienta

devoradora

su retorno!

Pintadas con sangre he visto las quillas de los barcos

las quillas ensangrentadas

he visto con sangre del Muntu.

He visto los negros socavones de las minas

iluminados con el resplandor de sus huesos,

huesos de mis huesos,

huesos de mis hijos y los hijos de mis hijos

blanca llama de muerte

iluminando el socavón de las minas.

He oído el silencio de los pájaros

asustados por el crujir de las cadenas

en la madrugada,

en la noche

bajo el sol

el crujir de las cadenas

silenciando el canto de los pájaros.

¡Eía! iEía! ¡Eía!

¡La tiránica

la ciega

maldición de Changó! (Zapata, 1997, pp. 64-65)

Este contexto permite comprender el desarrollo de la lucha por la libertad de los negros esclavizados durante el siglo XVI. Algunas prácticas como la construcción de fortalezas les permitió resistir a la esclavitud negra, es el caso de la "lucha con fortalezas de palos, denominados palenques” (Wabgou, M., Arocha, Salgado, \& Carabalí, 2012, p. 55). 
En las prácticas de resistencia que se documentan en la investigación realizada por la Universidad Nacional (2011), se relaciona la fuga de esclavos que huían de sus amos y se escondían en la selva donde se encontraban con indígenas, quienes les enseñaron formas de supervivencia en este espacio salvaje y los resguardaron allí. También se narra la compra de la libertad propia o la de sus compañeros, junto con la defensa jurídica y las fugas colectivas de esclavos. En este escenario, se ubica el origen del pueblo chocoano, con el liderazgo de Benkos Biohos quien logró la libertad de pueblo cimarrón, considerado como el primer pueblo libre de América en 1713. Este proceso de liberación del pueblo chocoano, lo llevó a conformar un pueblo olvidado por el Estado llegando a la situación de marginación actual. También se documenta la invención de la lengua palanquera, que fue el producto de la combinación entre el Bantú, lengua originaria del África, con lenguas criollas. En esta forma, el término palenque significa la lengua de resistencia, y la práctica de construcción de trincheras para la defensa militar de la libertad, lograda por los cimarrones.

Después de estos procesos de resistencia, se desarrolló una clase negra en el proceso de independencia, dado que esta fue una promesa de Bolívar "quien lo ayudara en la independencia le entregaría su libertad" (Wabgou, M., Arocha, Salgado, \& Carabalí, 2012, p. 55). En este contexto, surge la figura del Almirante Padilla que representa a los afrodescendientes en la Batalla de Maracaibo (24 de julio de 1823). Este almirante negro, cinco años más tarde, fue condenado a muerte, tras ser acusado de conspirar contra la libertad, lo que impidió el cumplimiento de la promesa de Bolívar sobre los afrodescendientes.

Con el fortalecimiento de los liberales, en el gobierno de José Hilario López, en 1851, se reconoció la libertad de los esclavos que, en su gran mayoría, eran negros, lo que implicará que en el desarrollo de la historia colombiana la participación de los afrodescendientes en el Partido Liberal sea un hecho recurrente, logrando que la mayoría de afrodescendientes asumiera y defendiera este partido. En el siglo XIX, se destacó la formación de una clase intelectual negra, ligada a la eliminación del analfabetismo; es el caso de Luis Antonio Robles Suárez (senador y fundador de la Universidad Libre), Manuel Saturio Valencia (autodidacta defensor de la libertad negra mediane el cuestionamiento 
de la "blancocracia"), Manuel Hernández (líder campesino asesinado asesinado). (Castilla, p. 1).

En la década de los treinta, se destacaron figuras como Diego Luis Córdoba que hizo parte de la élite, y representó el liderazgo político chocoano más relevante, fue fundador del movimiento Acción Democrática en 1933; Manuel María Villegas en la formación del Colegio Liberal. Entre 1940 y 1960, se construyeron escenarios para el análisis de la esclavitud negra en Colombia. El 20 de junio de 1943, conocido como "el día del Negro", se celebró una movilización contra el racismo global. Este mismo día, se creó el Club Negro, en el cual participaron Manuel Zapata Olivella y Natanael Martínez, ente otros. En 1947, se fundó el Centro de estudios afrocolombianos bajo el lema "Raza y Tierra".

Para estos personajes, la libertad implicaba la no subordinación económica y política a la clase dominadora, sobre todo de Popayán, para lo cual había que recurrir a la educación y a la posibilidad de adueñarse de los medios de producción y las ganancias derivadas de sus actividades económicas; todo ello, desembocando en el ascenso social de la gente negra. En resumen, y de acuerdo con Pisano (2010: 180-198), se trataría de ver "la construcción de infraestructuras como política 'racial", "la educación como medio de emancipación de la gente negra”, "la 'raza' y la tierra. La defensa de la propiedad campesina" (sobre todo a nivel rural). Haciendo un contraste con la actualidad, pensamos que estos personajes eran unos visionarios porque reclamaban unas políticas públicas para su región desde el enfoque del Desarrollo Humano. Este tipo de políticas públicas consistiría en generar: 1) una capacidad de generación y difusión de conocimientos de las poblaciones afros, en general, y de sus sectores pobres mediante el fomento de la educación y fortalecimiento del sistema educativo; (2) una libertad de agencia; es decir, "la capacidad de uno mismo para potenciar metas que uno desea potenciar" (Sen, 1995, citado por Tubino, 2009: 5), o bien "para ser o hacer aquello que tenemos razones para valorar” (Ibíd.).; (3) un mayor acceso de las personas más necesitadas a los alimentos mediante sistemas de asistencia 
directa y protección social, y (4) un fortalecimiento de la presencia y capacidad del Estado y de las organizaciones sociales en los municipios de los departamentos con mayor población afro para mejorar la seguridad alimentaria y nutricional en los grupos más vulnerables (tales como las mujeres gestantes, madres en lactancia y los/as niños/as menores de cinco años), ya que el empoderamiento debe conllevar una reforma institucional porque la falta de negociación que caracteriza a estos actores está enmarcada en "la naturaleza de las relaciones institucionales". (Fride, 2006: 6) (Wabgou, M., Arocha, Salgado, \& Carabalí, 2012, p. 83)

En 1970, el movimiento afrodescendiente en Colombia empieza a asumir su lucha histórica, ligada a la crítica contra el Apartheid. Se presenta el "Primer Encuentro Nacional de la Población Negra Colombiana" en 1975, en Cali, y se fundó el Movimiento de Negritudes en Colombia, el Centro para la Investigación y Desarrollo de la cultura Negra, la Revista Negritud, y se creó la Universidad del Pacífico. El año siguiente, se celebró el Segundo Encuentro Nacional de la población negra colombiana en Quibdó. 1977 es un año de asociación y reflexión académica cobre la cuestión de las negritudes en Colombia con el Congreso de negritudes de Medellín, el Tercer Encuentro Nacional de la población negra colombiana, el primer Congreso de la Colombia Negra de las Américas en Cali. Estas acciones ulminan a finales de los años setenta con la formación del Movimiento Nacional Cimarrón. En estos eventos, se rescata el sentido de la reivindicación negra en Colombia y en América para la identidad del negro y las condiciones de marginación económica, social, política y cultural. La discusión giró en torno a la disyuntiva teórica entre Racismo vs. Clasismo, como origen teórico de la esclavitud negra.

Pero, se debe destacar que en los años 70 el movimiento afrocolombiano se ha visto nutrido y fortalecido también por el saber y el compromiso de personas negras que ejercían la profesión de educadores, docentes, pedagogos, instructores o profesores, al igual que la abogacía. Así, no cabe duda que el movimiento que surge en esta época también se ha beneficiado de la labor del sector magisterial, debido a la implicación de muchos afrocolombianos 
en el magisterio, combinando el mundo académico y pedagogía con la praxis activista en defensa de los derechos de las poblaciones afrocolombianas, negras, raizales y palenqueras. El significado del aporte que hicieron algunos integrantes negros del sector magisterial colombiano, de forma individual o colectiva (desde la Unión Magisterial, las Organizaciones Magisteriales o la Federación de Organizaciones Magisteriales), es lo que subraya Ventura Díaz Ceballos (entrevistado en Bogotá, junio de 2011): Bueno del 60-70 hubo mucho movimiento magisterial, muchos chocoanos empezaron a salir de una forma más masiva a Bogotá y se vinculaban a los movimientos magisteriales. Movimientos estudiantiles de la Nacional, movimientos de otras universidades como la Distrital, en el Cauca y en el Valle, también hubo ese tipo de vinculación de algunos líderes afros que jugaron un papel muy importante en la Nacional, incluso encontramos a Heriberto Valencia y a algunos jóvenes que lucharon contra la reforma educativa que se daban en estas universidades. (Wabgou, M., Arocha, Salgado, \& Carabalí, 2012, p. 119)

Una figura relevante de este contexto fue Monseñor Gerardo Valencia Cano, Vicario de Buenaventura, quien, al acogerse a la Teología de la liberación y la Doctrina Social de la Iglesia, lideró la liberación política afrodescendiente y la integración social de los negros en Colombia.

En los años ochenta, las reivindicaciones negras estuvieron ligadas a la búsqueda de protección del Estado en el abastecimiento de servicios públicos de las regiones con población negra, como en el Chocó, Buenaventura y Tumaco, sin tener una respuesta positiva del Estado. Este silencio condujo a enfrentamientos sociales como fue el "Tumacazo" el 16 de septiembre 1988, por el corte de la luz durante 23 días.

En Tumaco (Pacífico Sur nariñense), se registra "el tumacazo", denominación que se refiere al paro cívico del 16 de septiembre de 1988 y que implicó una explosión de ira popular contra el gobierno colombiano por el incumplimiento en la provisión del servicio de la luz — que fue cortada durante 23 días, del 24 de agosto al 15 de septiembre de 1988- Bajo el liderazgo del movimiento 
cívico denominado "Tumaco Alerta sos", apoyado por algunas organizaciones de carácter cultural (construcción discursiva en torno a la etnicidad negra) e izquierdista (tales como el Moir y el M-19), se convocó una manifestación de protesta y movilización general con banderas y jirones reivindicativos en torno principalmente al mejoramiento de los servicios públicos, entre los cuales se destacaba la crisis en el servicio de energía eléctrica. En efecto, aunque la falta de luz en el municipio tumaqueño durante los días ya mencionados fue el elemento desencadenante de las protestas ciudadanas, se precisa que el cúmulo de las frustraciones a que habían sido sometidos los/as ciudadanos/as desde años atrás como resultado de las "décadas de olvido" de Tumaco, la no inversión de un alto porcentaje de los auxilios y dineros en la reconstrucción del pueblo después del devastador maremoto61 ocurrido el 12 de diciembre de 1979 y el descuido desvergonzado del municipio por parte de las autoridades locales y, especialmente, nacionales demostraban toda la indiferencia e inacción ante las necesidades básicas del pueblo tumaqueño. (Wabgou, M., Arocha, Salgado, \& Carabalí, 2012, pp. 133-134)

Como ocurrión con el movimiento feminista colombiano, la política desarrollada por el estatuto de Seguridad Nacional del expresidente Julio Cesar Turbay Ayala debilitó las organizaciones sociales y políticas con la persecución de líderes sociales ${ }^{3}$. Este escenario es reiterado en el movimiento afrodescendiente lo que tuvo consecuencias negativas para la organización. Entonces, los afros sintetizaban sus reivindicaciones en tres puntos: "Conciencia colectiva, estética y expresiva de su identidad, asociaciones para la apertura del comercio y justicia social y étnica que asegure la participación ciudadanía de los negros en Colombia.

También hace parte del contexto político de esta década el proceso de paz con las guerrillas impulsado por el presidente Belisario Betancur,

3 Es preciso destacar que en este periodo, el movimiento social afro no luchaba directamente contra el racismo sino que perseguía el reconocimiento de los derechos económicos, sociales y culturales. 
que tuvo lugar entre 1982 y 1986, periodo en el que esas organizaciones armadas incrementaron su control sobre varias áreas del país:

Desde 1982, durante el gobierno del presidente Belisario Betancur, que se propuso por primera vez en Colombia, adelantar discusiones pluralistas sobre la reforma política y la paz, así como diálogos con la guerrilla para buscar una solución negociada al conflicto armado. Aunque estos esfuerzos no dieron resultados esperados, sí marcaron la nueva etapa de búsqueda de paz (Ramírez, 2003: 275). En esta década el país vio con terror el surgimiento del paramilitarismo, que fue en buena parte el resultado de las estrategias estatales para la confrontación armada al margen de la ley contra la subversión; todo ello ha conllevado masacres, persecuciones, desapariciones forzadas, mientras los asesinatos de líderes se registraban diariamente en el acontecer nacional. Lo anterior se encontraba íntimamente relacionado con el narcotráfico. Se ha demostrado que los paramilitares bebieron de las fuentes de éste y utilizaron sus estrategias para el dominio del territorio, lo que años más tarde se conocería como la “cooptación del Estado". En este sentido, el narcotráfico y el paramilitarismo naciente en esta década dejaron su mortal tinta indeleble en el movimiento social por el resto de siglo xx y lo que llevamos del siglo xxi. Pues, es interesante ver cómo todo ello desembocó en la convocatoria de la Constituyente que incluirá lo más diverso de la sociedad colombiana, marcada por una ebullición democrática. (Wabgou, M., Arocha, Salgado, \& Carabalí, 2012, pp. 137-138)

Finalizando este periodo, se fundaron organizaciones negras como Cimarrón, Actuar, Asimongana, Periódico Oiga Sangre, Revista Palenque, Círculos de estudio Manuel Saturio Valencia, Asociación Campesina Integral del Atrato, entre otras. Esta última tuvo el liderazgo del Sacerdote Emigdio Cuesta cuyo aporte se resume en la consigna "transformación, lucha por la paz, educación y contra el racismo" (Wabgou, M., Arocha, Salgado, \& Carabalí, 2012, p. 143). En este escenario, se da una movilización ambiental por la defensa de los bosques y de la madera chocoana ante la posible intervención de multinacionales en sus territorios, lo que propicia la llegada del paramilitarismo. 
Esto representa otro elemento para comprender el sentido de la lucha y de la afirmación de la paz del movimiento afrodescendiente hasta la actualidad.

Con la Asamblea Nacional Constituyente los afrodescendientes buscaron obtener un lugar de participación en la formulación de la Constitución de 1991. Sin embargo, no lograron ni un solo lugar, por lo que realizaron una alianza estrategia con los pueblos indígenas que terminaron por representar la diversidad étnica y cultural en la Constitución. De esta participación, se obtuvo el artículo quinto que dice: "El Estado reconoce, sin discriminación alguna, la primacía de los derechos inalienables de la persona y ampara a la familia como institución básica de la sociedad” (CP, 1991, art. 5). Este artículo que buscó la eliminación de la discriminación permitió la creación de la "Comisión Especial para Comunidades Negras" que debía desarrollar el artículo $5^{\circ}$, mediante un texto que permitiría la expedición de una ley que los reconociera, lo que condujo a la creación de la Ley 70 de 1993. También se destaca de este proceso el reconocimiento de los derechos del pueblo Raizal, ubicados en San Andrés y Santa Catalina:

Artículo 310. El Departamento Archipiélago de San Andrés, Providencia y Santa Catalina se regirá, además de las normas previstas en la Constitución y las leyes para los otros departamentos, por las normas especiales que en materia administrativa, de inmigración, fiscal, de comercio exterior, de cambios, financiera y de fomento económico establezca el legislador. Mediante ley aprobada por la mayoría de los miembros de cada cámara se podrá limitar el ejercicio de los derechos de circulación y residencia, establecer controles a la densidad de la población, regular el uso del suelo y someter a condiciones especiales la enajenación de bienes inmuebles con el fin de proteger la identidad cultural de las comunidades nativas y preservar el ambiente y los recursos naturales del Archipiélago. Mediante la creación de los municipios a que hubiere lugar, la Asamblea Departamental garantizará la expresión institucional de las comunidades raizales de San Andrés. El municipio de Providencia tendrá en las rentas departamentales 
una participación no inferior del $20 \%$ del valor total de dichas rentas. (CP, 1991, art. 310)

Con la ley 70 de 1993 (Ley de Negritudes) se definió el concepto de etnicidad, se consagró el reconocimiento de la propiedad colectiva de los afrodescendientes en Colombia y se reconocieron los recursos naturales con la participación de la Dirección de Asuntos de Comunidades Negras y se creó la circunscripción electoral a favor de las personas afro. Además, se fundó la cátedra de estudios afrocolombianos, de la etnoeducación y de las prácticas tradicionales de esta comunidad, que es un instrumento trascendental para reconocer y defender los derechos de la población negra en Colombia.

A pesar de la creación de estas normas, el sentido de la discriminación cultural hacia los afrodescendientes en Colombia no cambió, por lo cual fue necesario en esta investigación hacer un breve estudio sobre el impacto de la violencia de los años noventa, en la que el desarrollo del paramilitarismo en Colombia impidió el desarrollo de los Derechos Económicos, Sociales y Culturales de esta población. La marginación de este territorio se agudizó, lo que lo hizo propicio para ser un lugar relevante en el conflicto colombiano, lo que obstaculizó el desarrollo de los derechos de las comunidades negras y entorpeció las organizaciones y el sentido de sus luchas en contra de la discriminación, que adoptaron el discurso de víctimas del conflicto, que pasó a ser la condición de las organizaciones afrodescendientes en Colombia.

\section{Impacto del conflicto armado en el Movimiento social afrocolombiano}

Las comunidades afrodescendientes crearon organizaciones que le dieron continuidad a sus reivindicaciones que, con el conflicto armado, se han radicalizado en materia de tierras, dado que el paramilitarismo se presentó de manera paralela a la llegada de multinacionales extractivas que buscaron despojar a estas poblaciones de sus territorios. El desarrollo de los grupos armados se presentó ante la necesidad de tomar tierra donde pudieran vivir y organizarse para el sustento y también para la acción bélica, de modo que el territorio 
de las comunidades negras se convirtió un escenario propicio para esta actividad, por el olvido del Estado y por su ubicación espacial propicia para los corredores del comercio de drogas y de armas. Esto ocasiono el desplazamiento forzado sobre los afrodescendientes en Colombia, expresado en la formación de organizaciones como Afrodes (Asociación Colombiana de Afrocolombianos Desplazados):

Registra la Asociación de Afrocolombianos Desplazados (Afrodes), que nació en el año 1999 como respuesta al fenómeno del desplazamiento forzado que golpea a la comunidad afrocolombiana en sus territorios ancestrales y que les obliga a buscar refugio en lugares como Bogotá: "La organización surge entonces para defender los derechos de la afrocolombianidad desplazada, buscando en primer lugar condiciones de 'existencia digna' para la gente durante la 'transitoria' condición de desplazamiento y, a su vez, exigir las condiciones necesarias para el retorno de la misma a sus territorios [...] Afrodes surge como una necesidad de interlocución entre las familias desplazadas por la violencia y el Gobierno y demás entidades que atienden problemas de esta naturaleza, ya que pese a existir otras organizaciones de desplazados no recogen la problemática específica de la población Afrocolombiana. (Wabgou, M., Arocha, Salgado, \& Carabalí, 2012, p. 190)

La labor de Afrodes se afianzó con el desarrollo de informes que documentan la situación de afrocolombianos en relación con las violaciones de los Derechos Humanos causadas por el conflicto armado. En el Informe presentado al Comité para la Eliminación de la Discriminación Racial (CERD), en su $75^{\circ}$ periodo de sesiones, en el que se consideró el informe presentado por el gobierno en junio de 2009:

La discriminación racial y la exclusión (social, económica, política y cultural) son realidades vigentes en la experiencia contemporánea del Pueblo Afrocolombiano, y de manera agravada para la población afrocolombiana en situación de desplazamiento forzado. La ausencia de un reconocimiento estatal sobre las interrelaciones entre estas dos formas de vulneración a los derechos fundamentales de este grupo étnico, en razón de una concepción limitada 
de la categoría "discriminación racial", se constituye en uno de los factores críticos que impiden la adopción de las políticas públicas requeridas para transformar estas realidades. [...] El reconocimiento de la dimensión étnica implicada en los fenómenos de discriminación, violencia y exclusión que se registran en Colombia, constituye una condición necesaria e inaplazable para detener los procesos de violación sistemática contra los derechos del Pueblo Afrocolombiano. A pesar del reconocimiento formal sobre los fenómenos de exclusión estructural y los impactos diferenciales del conflicto armado sobre el Pueblo Afrocolombiano, la adopción de políticas públicas efectivas que incidan sobre las causas estructurales de los mismos, continúa siendo un proceso incipiente que no tiene correspondencia con la magnitud y características de las problemáticas que se están enfrentado, las cuales están aniquilando sistemáticamente nuestras posibilidades de supervivencia física y cultural. (Afrodes, 2009, p. 1)

Este proceso de desplazamiento sobre la población afrodescendiente ha sufrido un deterioro sobre la defensa del derecho a la igualdad y la diversidad étnica, cultural y racial de las comunidades negras en Colombia porque su ubicación territorial coincide con puntos estratégicos para el desarrollo de la guerra junto con centros de explotación forestal. Igualmente, se ha acentuado la marginación y el olvido del Estado en esta población. De acuerdo con el informe presentado por Afrodes en el Censo poblacional del 2005, se documenta la existencia de "4261996 ciudadanos afrocolombianos" (Afrodes, 2009, p. 6). También se observó que, en los años setenta, las comunidades afrodescendientes vivían en situación de exclusión:

El carácter estructural de la exclusión del Pueblo Afrocolombiano fue nuevamente comprobada en los últimos ejercicios orientados hacia la formulación de un Plan Integral de Largo Plazo de la Población Negra-Afrocolombiana, Palenquera y Raizal (2007-2019). [...] La meta de los actores armados y los agentes económicos (legales e ilegales) consiste en desterrarnos de los territorios ancestrales o despojarnos del ejercicio autónomo de los derechos étnico-territoriales consagrados en las leyes y los instrumentos internacionales 
suscritos por el Estado colombiano. (ii) la cifra de referencia para una política pública con enfoque diferencial no sería inferior a los 700 mil afrocolombianos y podría llegar hasta 1.4 millones, (iii) la tendencia del desplazamiento, para el caso de los municipios del Pacífico colombiano, registro un aumento sistemático durante los últimos cuatro años, y (iv) en estos municipios existe una concentración de 266219 personas desplazadas. [...] El proceso de destrucción cultural contra el Pueblo Afrocolombiano queda evidenciado y registrado de manera contundente al observar las cifras de desplazamiento específicas para los 50 municipios en donde están los territorios ancestrales reconocidos legalmente hasta hoy: a diciembre de 2007, 294842 personas habían sido expulsadas de los 50 municipios; esta cifra representaría el 93\% de los 318647 habitantes que fueron censados en el proceso de adjudicación de los títulos colectivos. (Afrodes, 2009, pp. 6-7)

Afrodes manifiesta en su informe la importancia de comprender la problemática de los pueblos afrodescendientes por tratarse de personas de trato especial, puesto que recalca el papel de las mujeres afrodescendientes desplazadas, que sufren tres tipos de discriminación, ser negra, ser mujer y ser desplazada. Por ello, se dedica un capítulo del informe a la necesidad de examinar la violencia estructural contra la mujer, con el fin de buscar un fortalecimiento institucional que conduzca a una protección especial reforzada. La cifra que muestra Afrodes en 2007 es de 200000 mujeres negras desplazadas de municipios del Pacífico colombiano, que han sido reconocidos por el Estado como territorios de propiedad colectiva de comunidades negras.

Otras organizaciones de comunidades afrodescendientes como Afroamérica XXI y el Colegio de Abogados Afroamérica XXI presentan en el informe alternativo Afroamérica XXI "Colombia 2000-2008", presentado ante el CERD, la situación del pueblo afrodescendiente en Colombia, y señala cuatro puntos geográficos de alta relevancia poblacional para las comunidades negras: el Pacífico, San Basilio de Palenque, Raizales y Cabeceras municipales y ciudades. En el pacífico se documenta la existencia de 132 territorios colectivos reconocidos y titulados donde persisten prácticas culturales afrodescendientes, 
en los raizales, se ubica en el archipiélago de San Andrés, Providencia y Santa Catalina. En San Basilio de Palenque, se muestra la importancia de este territorio para las comunidades negras porque representa el legado histórico de libertad de 1603. En las cabeceras municipales y las principales ciudades, se destaca el territorio de Valle del Cauca, Bolívar y Antioquia con presencia de pueblos afrocolombianos. Sin embargo, de acuerdo con este informe, las comunidades afrodescendientes, dada su ubicación geográfica, viven en situación de marginación, pobreza y violencia, por la guerra y por el olvido del Estado. Por ello, el fenómeno del desplazamiento es el principal factor que ha deteriorado a estas comunidades.

En la sentencia T-025/04 (2004) se da la declaración de la Corte Constitucional del estado de cosas inconstitucional con ocasión del desplazamiento, al reconocer que el $50 \%$ de la población desplazada es afro. Se certifica la gravedad de las comunidades ubicadas en Buenaventura por el desarrollo de la violencia y el desplazamiento, donde el $85 \%$ de la población afrodescendiente vive en situación de miseria como consecuencia del conflicto armado. En el año 2006, se registraron 592 asesinatos, lo que produjo un clima de miedo entre los habitantes que derivó, en el segundo semestre de ese año, el desplazamiento de 1500 personas. Se denuncia el Decreto 092 de abril de 2007 (enero 17) que permitió el abuso de poder de las autoridades que afectó a la población infantil.

Esta situación de violencia es analizada por la investigación "Población Afrocolombiana / Negra, Palenquera y Raizal y Derechos Humanos" de June Marie Mow, investigadora de Indepaz (2012) en el que se muestra que las sentencias de la Corte Constitucional Colombiana han reconstruido histórica y jurídicamente el impacto del conflicto armado interno sobre la población afrodescendiente. Es el caso del Auto 092 (2008) donde se narra la violencia sexual contra las mujeres afrodescendientes como una estrategia bélica para deteriorar a las comunidades y lograr el control territorial, mediante el miedo y el dolor de las familias, lo que obstaculiza el desarrollo de estas poblaciones. También menciona la sentencia T-586/07 (2007) en la cual la Corte Constitucional indica la necesidad de reconocer la situación de marginación de la población negra en Colombia. Finalmente, en la 
sentencia T-422/96 (1996) donde se manifiesta la vigencia del racismo en Colombia. De acuerdo con Mow, la legislación nacional expone a la violencia estructural contra los afrocolombianos dada la falta de reglamentación de la ley 70 de 1993, lo que provoca procesos de marginación y de anulación de la participación de las comunidades negras, por la falta de procesos de desarrollo articulados con políticas étnicas y raciales, como un referente contextual determinante en el conflicto armado al localizar territorios propensos para el desarrollo de los enfrentamiento violentos entre los grupos armados, cuyo resultado se concreta en el desplazamiento de los afrocolombianos.

La falta de compromiso efectivo para concretar la reglamentación de la Ley 70 se ha visto agravada por los intentos del Estado para crear leyes que amenazan los derechos conquistados y refuerzan los procesos de exclusión. En esta línea, deben mencionarse la Ley Forestal (Ley 1021 de 2006) y la Ley/Estatuto de Desarrollo Rural (Ley 1152 de 2007) que precisamente han sido declaradas inconstitucionales por haber omitido los procesos de Consulta Previa con las comunidades étnicas (indígenas y afrocolombianos). La expedición de estas dos leyes implicaba un conjunto de arreglos institucionales que claramente facilitaban la vulneración de los derechos étnicos por parte de los agentes económicos. 30. La adopción de un Plan Integral de Largo Plazo de la Población NegraAfrocolombiana, Palenquera y Raizal (2007-2019) se ha incluido en las metas de los dos últimos Planes de Desarrollo Nacionales, con la perspectiva de que sea una política pública que realmente se constituye en una alternativa de carácter estructural. A pesar de los avances en su proceso de formulación, al igual que iniciativas previas similares, la implementación no se ha hecho efectiva en razón de la ausencia de las condiciones políticas, institucionales y financieras que se requieren, la cuales deben ser provistas por el Estado colombiano. (Mow, 2010, p. 11)

En este estudio, se expresan cifras que indican la realidad relatada. De acuerdo con Mow (2010), Chocó tiene 15 años de atraso económico en relación con otros territorios promedio en el país, su esperanza de vida llega hasta los 66 años, la tasa de analfabetismo alcanza el 
$18 \%$, las pruebas de educación nacional se encuentran por debajo del promedio nacional, añadiendo la carencia de enfoques diferenciales en estas. En materia de salud, se registra que solo el $53 \%$ de la población tiene algún tipo de protección. De este porcentaje el $35 \%$ corresponde al régimen subsidiado. Estas cifras se expresaron en al año 2003 en el Plan Integral de Largo Plazo, lo que permite examinar el sentido actual de la discriminación racial en Colombia: territorios olvidados, marginados y sin procesos que los conduzcan a la integración nacional, ni al desarrollo, propiciando una violencia estructural por la carencia de articulación material de enfoques diferenciales en favor de estas comunidades que permiten el desarrollo de del conflicto armado, la violencia cultural, el desplazamiento y la discriminación.

En 2012, se publicó el informe de la Comisión Interamericana de Derechos Humanos, "Situación de las personas afrodescendientes en las Américas”. En Colombia, se documenta que el $10.67 \%$ de la población colombiana es afrodescendiente. Se expresa la falta de caracterización y de identificación precisa por el Estado de las condiciones de vida de esta población, cuya causa principal es el estado de marginación en que vive:

La población afrodescendiente está concentrada desproporcionalmente en las áreas residenciales más pobres y con mayor déficit de vivienda, poco accesibles con medios de transporte inadecuados y sufre mayor exposición al crimen y la violencia. (CIDH, 2012, p. 17)

El gobierno colombiano identificó como principales problemas de esta población:

49. De acuerdo con las respuestas recibidas, Colombia identificó los siguientes ejes problemáticos: i) baja productividad y competitividad de las actividades productivas, ii) bajos niveles de escolaridad debido a dificultades de acceso, permanencia y calidad del ciclo educativo, lo que dificulta la superación de la pobreza, iii) fragmentación del tejido social en función del desplazamiento forzado, iv) políticas, planes, programas, proyectos y normas insuficientes o que no se implementan de manera adecuada, v) prácticas sociales de discriminación racial. (CIDH, 2012, p. 25) 
De acuerdo con el Informe de UNHCR (2012) la población de refugiados en Colombia asciende a 3943827 , y entre ellos, la situación de afrodescendientes es grave, pues el $12.3 \%$ de la población afro se encuentra en condición de desplazamiento interno, de la cual, el $98.3 \%$ vive por debajo de la línea de pobreza.

Los efectos del conflicto armado interno han marcado significativamente las circunstancias en las que viven actualmente los grupos afro colombianos, palenqueros y raizales en Colombia. El desplazamiento forzado como consecuencia de la violencia ejercida sobre los territorios, comunidades y líderes ha debilitado los procesos organizativos de la población afro colombiana. De igual manera, el desplazamiento ha generado un grave impacto en la identidad la cultura y la autonomía de los pueblos afro colombianos que a su vez ha producido la pérdida del territorio de las comunidades que habitan territorios colectivos a pesar de la implementación de la Ley 70 de 1993. La Corte Constitucional en el auto 005 de 2009, concluyó, entre otras, las siguientes causas de desplazamiento para la población afrocolombiana: 1. La exclusión estructural que resulta en marginalización y vulnerabilidad; 2. La minería y los procesos agrícolas que imponen severas presiones sobre territorios ancestrales; 3. La debilidad en la protección judicial e institucional inadecuada de los territorios colectivos afro. (UNHCR, 2012)

Otro asunto que se destaca en el documento es la persecución y el asesinato de líderes afrodescendientes entre 2006 y 2012, para un total de 71 personas asesinadas, que participaban en procesos de restitución de tierras para afrodescendientes. De acuerdo con Afrodes y el Colectivo de Abogados José Alvear Restrepo, en el año 2013, se asesinó a un importante líder de Afrodes.

Diego Luis Balanta de la Asociación Nacional de Afrocolombianos Desplazados (Afrodes) fue atacado en Cali, Colombia. Un destacado defensor de derechos humanos, el señor Balanta fue tirado al piso por tres hombres y lo llamaron "sapo". Aunque el Sr. Balanta pudo escapar, se fracturaron dos de sus dedos en el ataque. Él ha tenido que dejar su casa para otro lugar en Cali. (Cajar, 2013) 
En el año 2014, se documenta la continuidad de combates de grupos armados en el territorio chocoano, que produce la mayor tasa de desplazamiento de territorios colombianos ${ }^{4}$. En junio de 2017, se documenta el asesinato del Fiscal Nacional de Afrodes como un hecho destacado de continuidad de violencia contra las comunidades afrodescendientes.

Bernardo Cuero Bravo, víctima de desplazamiento forzado, delegado por la organización Afrodes a la Mesa de Participación de Víctimas de Atlántico y miembro de la Junta de Acción Comunal del barrio Villa Esperanza, de Malambo, fue asesinado en ese municipio atlanticense.

Según la Defensoría del Pueblo, Cuero Bravo denunció reiteradamente amenazas en contra de su vida. Además, el mismo organismo, en su informe de riesgo 'Violencia y amenazas contra los líderes sociales y los defensores de derechos humanos', advirtió el peligro para las personas que realizan esa labor en Barranquilla, su área Metropolitana e integrantes de la Mesa de Víctimas departamental. (El Tiempo, 2017)

Es preciso concluir que el impacto del conflicto armado sobre las comunidades afrodescendientes ha sido alto en relación con otras regiones del país, y ha desestructurado el desarrollo de sus prácticas y de las identidades colectivas y culturales con los asesinatos y las persecuciones a líderes afrodescendientes, con la comisión de violaciones y crímenes sexuales contra mujeres afrodescendientes, como se describió en el apartado sobre el impacto de la violencia contra la mujer afrodescendiente en Colombia, junto con el reclutamiento forzado y de desplazamiento de estas poblaciones. La ubicación territorial ha sido un factor central en el desarrollo de la violencia y el narcotráfico, por ser sectores olvidados por el Estado. Otro de los puntos cruciales

4 “Según el más reciente informe de la Consultoría para los Derechos Humanos y el Desplazamiento (CODHes), el Chocó tiene la mayor tasa per cápita de los desplazamientos en el país, lo que contribuye a la posición de Colombia como el país con la segunda población de personas internamente desplazadas más grande del mundo" (Cajar, 2014). 
es la falta de investigación y de protección por las autoridades colombianas que, al consentir la impunidad, permiten la repetición de estos hechos en el mismo territorio contra la misma población. Este es el escenario actual de las comunidades negras, lo que permite identificar el sentido y la necesidad de participar en el proceso de paz, pues no se trata solamente del sentido colectivo de las víctimas del conflicto armado, sino también de la afectación a la organización negra en contra de la discriminación estructural y cultural en su desarrollo histórico.

\section{El movimiento afrodescendiente en los foros de participación ciudadana}

Los pueblos afrodescendientes participaron en el Primer Foro de Participación Ciudadana sobre el primer punto del acuerdo, donde se buscó una reflexión sobre la tierra rural, sobre los derechos que tienen los campesinos como:

Sujetos de derechos ciudadanos y colectivos desde su pluralidad y desde la diversidad de sus comunidades, e incluye también su derecho a la tierra y al territorio, a la diversidad, a la participación, a la representación política plena y autónoma, con las correspondientes garantías para su ejercicio. (Universidad Nacional, 2012, p. 18)

Allí, se debatió sobre el modelo de desarrollo, donde fue importante el aporte de las comunidades afrodescendientes quienes argumentaron la necesidad del reconocimiento material de la propiedad colectiva de las comunidades negras, siendo este un pueblo raizal étnico del Archipiélago de San Andrés, Providencia y Santa Catalina que, ejerciendo el derecho a la autodeterminación, persigue construir un modelo de desarrollo sostenible, que ha sido afectado en sus territorios por el narcotráfico, el conflicto armado y la desatención del Estado. Es por ello que las comunidades afro exigieron una sociedad libre de racismo y de discriminación, y la reivindicación del papel de la mujer afro; requirieron reparaciones proporcionales a las violaciones sufridas por el conflicto armado, reivindicación de reparación individual y colectiva.

Desde la perspectiva colectiva, plantearon la necesidad de discutir los diálogos de la mesa de negociación de la Habana con las 
comunidades, porque los actores sentados no representan la identidad étnica y cultural del país. Para ellos, la reparación debe ser proporcional, integral con responsabilidad del Estado, porque este debe tener en cuenta el rol de la cultura para construir lazos sociales de reconciliación. Proponen construir un foro de cultura de paz que parta de reconocer la diversidad cultural colombiana y el rechazo a la discriminación como punto de partida para edificar la Paz.

La mesa Afrocolombiana planteó la articulación constante sobre el asunto de tierras entre territorio, identidad, participación y desarrollo desde una perspectiva de derechos colectivos, puesto que su afectación fue conjunta y sistemática en el marco del conflicto armado. Por ello indicaron la importancia de construir una nueva Nación Pluriétnica y multicultural que valore la diferencia y la autodeterminación de los pueblos étnicos. "Para los afro, la paz está relacionada con el buen vivir y la tranquilidad de restablecer el legado de sus ancestros" (Universidad Nacional, 2012, p. 31). Se requiere que los territorios ancestrales afro sean tratados como autónomos y como territorios de paz para reconstruir el tejido social que ha sido perjudicado en su cultura y su conocimiento ancestral. Y que la reparación y el contenido del acuerdo "no vaya en detrimento de sus luchas históricas" (Universidad Nacional, 2012, p. 32).

El segundo foro de Participación Ciudadana, sobre el Punto de Participación Política, se realizó en abril de 2013. En este foro participaron activamente las comunidades negras. Se resalta la ponencia presentada por la Mesa Nacional de Organizaciones Afrocolombianas a cargo de Juan de Dios Mosquera. El vocero de la Mesa recordó que se conmemora un año más de la masacre de Bojayá, que permite mostrar cómo la cantidad de desparecidos simbolizan la violencia histórica contra la población descendiente de esclavos. La Mesa estableció que, para el pueblo afrocolombiano, el cese de los fusiles es una oportunidad que garantiza un nuevo modelo de sociedad, una democracia que no discrimine y que reconozca los conflictos históricos no resueltos e ignorados por la población "española colombiana". Se pidió que se reconozca el enfoque diferencial afrocolombiano en todos los temas y contenidos de los acuerdos que sean producto de los diálogos de La Habana, partiendo de la eliminación de las prácticas clientelistas, 
en particular aquellas en las que la población afro es utilizada políticamente y que cierran la posibilidad de participación directa de las comunidades afrodescendientes, proponiendo y apoyando una Asamblea Nacional Constituyente que permita una articulación étnica y cultural de los afrodescendientes.

En la primera relatoría, se propuso la creación de un canal televisivo donde se publique, informe y eduque a Colombia sobre la diversidad étnica y cultural, específicamente sobre los afrodescendientes. En la segunda relatoría, se hizo énfasis en la participación de una Asamblea Nacional Constituyente propuesta por los afrodescendientes, así como la importancia de garantizar la gobernanza popular e interétnica de territorios colectivos, reconocidos como entidades electorales con gobierno propio.

\section{Movimiento social indígena en Colombia}

\section{Breve historia del Movimiento social indígena y el impacto del conflicto $\operatorname{armado}^{5}$}

Con el descubrimiento del Nuevo Mundo, se introdujo la cosmovisión occidental de ciencia, progreso, verdad y discurso a los pueblos no occidentalizados, entre ellos, los pueblos indígenas que habitaban la Abya Yala. Se instaura un sistema de colonización que, a diferencia del continente africano, sufre una suerte de mestizaje con la llegada de los esclavos afrodescendientes al Nuevo Mundo, que fue nombrado por los españoles como zambos, mestizos, mulatos, blancos, negros, salto-atrás e indígenas. Entre estos, se dan combinaciones genéticas y una hibridación cultural que se caracterizó por la imposición de la lengua, la religión, el sentido de vida, la comprensión científica del mundo y la construcción de verdad de la cultura colonizadora del norte. En esta forma, los procesos de construcción de los derechos de los

5 Dada la extensión y las implicaciones del conflicto armado a lo largo de la historia de los pueblos indígenas se prefirió fusionar estos dos aspectos en un solo numeral a diferencia de los demás movimientos. 
pueblos indígenas en Colombia desde abajo son el resultado de luchas históricas de resistencia que comprenden figuras de líderes indígenas, luchas sociales, paros nacionales, toma de carreteras (en especial la vía panamericana), movilizaciones sociales, mingas nacionales, congresos, consolidación de organizaciones regionales y nacionales que expresen la unidad de la resistencia indígena, así como periódicos mediante los cuales se reconstruye la historia del derecho a resistir y a existir, con la legalización de sus derechos que implica tanto su afirmación como su limitación en la constante búsqueda de: tierra, autonomía y cultura, que hasta nuestros días se ha visto limitada por contextos de violencia y de desarrollo que han implicado la anulación de la vida individual y colectiva de nuestros pueblos indígenas.

La primera legislación que reconoció el derecho a la propiedad colectiva, a los resguardos y a los cabildos indígenas fue la Ley 89 de 1890 (25 de Noviembre) "Por la cual se determina la manera como deben ser gobernados los salvajes que vayan reduciéndose a la vida civilizada", que ha sido el fundamento jurídico para la defensa de los territorios indígenas hasta nuestros días. Fue esta ley la protagonista de las luchas de resistencia de los pueblos indígenas pasando por la labor de Manuel Quintín Lame de darle publicidad por todo el territorio colombiano mediante el diario "El Espectador".

Es esta ley y no otra expresa el sentimiento del libertador Simón Bolívar de reconocer la labor de los indígenas por haberlo acompañado en la guerra con los comuneros, otorgando este regalo en favor de estos pueblos. Sin embargo, esta regulación tiene la paradoja de reconocer la propiedad de la tierra y también de la tutela de los indígenas, hecho que ha ocasionado dificultades en su materialización. No obstante, son más los beneficios y las conquistas de las resistencias indígenas que ha producido esta regulación, por lo cual es de especial protección y trascendencia para la historia del reconocimiento de los derechos de los pueblos indígenas en el país.

Manuel Quintín Lame Chantre, de ascendencia étnica nasa, nació el 31 de octubre de 1883 en el Cauca y murió el 07 de octubre de 1967 en Ortega, Tolima. Estuvo 108 veces en prisión, tuvo en su contra 8000 expedientes judiciales con ocasión de su apostolado por la causa indígena. A pesar de haber nacido en el Cauca y de ser indígena aprendió el 
discurso del Derecho, mediante el cual ejerció su acción por la causa indígena y se auto defendió en distintos procesos judiciales en su contra. Estas fueron luchas que más tarde conducirían a la titulación y el reconocimiento de los resguardos de Ortega y Chaparral en 1948. Tuvo una vida de persecución, viajó del Cauca a Tolima, del Tolima a Quito, y de allí nuevamente al Cauca y luego al Tolima donde fallecería con la gracia de haber vivido una vida de lucha por el derecho a la resistencia de los pueblos indígenas, su instrumento de trabajo cotidiano fue su identidad en la defensa de la Ley 89 de 1890, la "Ley especial". En sus obras, se destaca la creación de la "Escuela Llano Grande" en el Tolima para los ancianos, a quienes enseñó a leer y a escribir con el fin de que supieran defender su territorio y su cultura, y también su obra: "Los pensamientos del indio que se educó en la selvas colombianas" (1924), junto con sus cartas y manifiestos, como es el caso de la "Circular primero de mayo de 1916":

Ellos, para apropiarse de nuestras comarcas nos declararon salvajes, y desde luego fuera de la humanidad y en nombre de la civilización, contra toda justicia y contra toda ley y, sin más razón que la de ser más fuertes, nos despojaron de las tierras que habíamos poseído siglos tras siglos sin interrupción alguna. Nuestros padres defendieron con heroísmo sus dominios y no hay selva americana que no esté regada con su sangre, y los huesos de nuestros antepasados desde el mar Caribe hasta la Tierra del Fuego, piden y esperan venganza. Entonces por la actitud heroica de nuestros padres, por la manera encarnizada y tenaz con que defendieron sus dominios, los blancos comprendieron que el único medio de asegurar la posesión de las tierras que a sangre y fuego nos arrebataron, era mantenernos en la impotencia, y para ello, optaron primero por el asesinato en masa a fin de diezmar las tribus, y después para los que milagrosamente se salvaron y para sus descendientes, acordaron conservarlos en el más hondo salvajismo y en la mayor pobreza; medida eficaz para el fin que se proponían, porque nada esclaviza tanto como la ignorancia, ni nada abate los ánimos tanto como la miseria. De aquí el que estén nada errados los expositores que afirman que una de las 
principales razones que tienen los blancos para mantenernos en la opresión económica en que vivimos, más que el deseo de adueñarse de nuestro trabajo y de vivir del sudor de nuestras frentes, es el temor de que algún día podamos ser fuertes, capaces de reclamar con la fuerza nuestro derecho y de tomar nuevamente posesión de las tierras de que fuimos despojados violentamente. Los blancos mejor que nosotros saben que nuestro derecho a la tierra no prescribe, porque el derecho no prescribe cuando hay fuerza mayor de por medio. (Lame, 2010, pp. 48-49)

Cabe destacar la lucha contra "El Terraje", institución económica en la que se continuaba la relación de esclavitud entre terratenientes e indígenas, donde estos últimos, a cambio de vivir en unas cuantas hectáreas de tierra, debían retribuir, como contraprestación en favor del terrateniente, su trabajo en la tierra, incluyendo a sus hijos varones, y las mujeres y sus hijas debían prestar servicio doméstico en las haciendas, e incluso en algunos casos la hija menor se obligaba a entregar su virginidad al terrateniente o a quien este decidiera. Esta era una forma de explotación de la mano de obra a la que estaban forzados los indígenas, en especial los que habían sido desposeídos de sus resguardos y que, en calidad de terrajeros, le pagaban al hacendado en días de trabajo el uso y cultivo de pequeños globos de terreno en la hacienda. En la actualidad, la práctica del terraje ha sido eliminada en el Cauca en su totalidad, gracias a la labor del Consejo Regional Indígena del Cauca (CRIC) que tomó como inspiración para la organización la vida de resistencia de Quintín Lame.

En 1911, Quintín Lame comenzó un movimiento de resistencia al pago del terraje en las haciendas del Cauca. En la zona de Tierradentro, convocó a los indígenas a negarse a pagar este impuesto, lo que se transformó rápidamente en una lucha por la recuperación de los resguardos, el rechazo a las leyes de extinción de estos, la reivindicación de la autonomía de los cabildos y la denuncia de la discriminación racial contra los indígenas (Espinoza, 2003).

El objeto de la Ley 89 de 1890 fue determinar la administración que tendrán las comunidades indígenas, consideradas como "salvajes", como animales y que en razón de ello fueran integrándose a la vida 
civilizada, dejando de practicar su cultura y creencias como producto de las misiones religiosas. Con esto, se promueve la organización de los cabildos indígenas, los resguardos, los protectorados indígenas, la división de terrenos de los resguardos, y los contratos de venta. La posibilidad de ejercer un derecho de resistencia por estos pueblos indígenas estimada en esta ley no se oponen a la legislación estatal. Se establecen como deberes del cabildo realizar un censo anual de sus familias, registrar sus propiedades anualmente, proteger los instrumentos públicos que determinen las propiedades y los frutos que posean, distribuir proporcionalmente las tierras del resguardo, impedir su venta, arriendo o hipoteca.

De modo contrario, en concordancia con la Organización Nacional Indígena de Colombia (ONIC), la Ley 89 de 1890 permitió a mediados del siglo xx con su difusión por los medios de comunicación en el país que lo indígena se identificara con lo exótico, lo subversivo y lo invisible, como continuación de la imagen "degradada del indio":

Es una prolongación de la Bula del papa Paulo III que en 1537 descubre que los indígenas son como europeos, tienen alma y están dotados de sentimientos. Esta Ley establece dos categorías de indios: los Salvajes y los reducidos a la vida civilizada. Pero en general comparten el calificativo de menores de edad lo que afianza una imagen de incapaces, que no pueden valerse por sí mismos. (ONIC, 1995, p. 7)

En las primeras décadas del siglo xx, las luchas de resistencia se acentuaron, en especial en los años 20 y 30 con las caucherías de la "Casa Arana” que, según Juan Houghton (2008), actuaron mediante la esclavitud, la desterritorialización del pueblo Huitoto, junto con otros pueblos de la Amazonia en la frontera colombo-peruana. Estas prácticas, que atropellaban la dignidad humana de los pueblos indígenas, se extendieron en la región, como ocurrió en las "guahibiadas", donde no se aceptaba el ejercicio de derechos de los indígenas puesto que, aun en las prácticas sociales de los modelos desarrollistas no se comprendía la identidad indígena como expresión de la identidad de la dignidad humana. 
En 1969, como respuesta a la organización de los indígenas sikuanis en una cooperativa en la comunidad de Domo Planas (Meta), que obstaculizó su explotación por los colonos, estos, junto con el gobierno, organizaron una operación militar que produjo el asesinato de 30 líderes, el desplazamiento de la población, la quema de poblados indígenas, torturas, maltrato de niños y violación de mujeres. La denuncia por un sacerdote católico motivó un debate en el Senado, donde los responsables de los crímenes manifestaron reiteradamente: "Ni el indio es hombre, ni el casabe es pan": Estas incursiones también fueron conocidas como "guahibiadas", que eran criminales cacerías de indígenas realizadas por colonos con complicidad de la fuerza pública. En el juicio por masacres colectivas los acusados respondían que no consideraban un delito asesinar indígenas. (Houghton J., 2008, p. 87)

Conviene recordar el asesinato en 1944 de José Gonzalo Sánchez por los terratenientes. Este fue un líder indígena, compañero de Quintín Lame, quien continuó en los procesos de resistencia mientras que Lame se encontraba en prisión entre 1917 y 1920. Posteriormente, se distanciaron rotundamente debido a la perspectiva política de la defensa indígena, en el caso de José Gonzalo Sánchez asumió una perspectiva clasista de la explicación de la opresión indígena, e ingresó al partido comunista. Sus diferencias fueron tan drásticas que, de acuerdo con Mauricio Archila:

La disputa política involucra también los métodos de lucha. Mientras Lame desde los años 30 se mantiene en la brega por restituir los resguardos, por la vía jurídica y con epicentro en el Tolima, Sánchez participa decididamente en el esfuerzo de organizar a los indígenas como parte de la clase campesina, haciendo trabajo político en el Cauca y el sur del Tolima. Para el primero los cabildos siguen siendo el motor de la lucha, para el segundo estas formas tradicionales de gobierno indígena deben ser orientados por organizaciones clasistas, pues sospechaba que habían caído en manos de los partidos tradicionales. De esta forma si Lame mantiene un eje de identidad étnica con un creciente pragmatismo político, Sánchez opta — como era común en los círculos marxistas 
del momento- por la construcción de un movimiento campesino que incluyera a los indígenas y que utilizara métodos revolucionarios. Todo esto explica que con el paso de los años y el privilegio a la identidad étnica por parte del movimiento indígena caucano, la memoria de José Gonzalo Sánchez haya declinado a favor de la creciente recuperación de Manuel Quintín Lame (Archila, 2013)

Este entorno permite entender el desarrollo de la ley 135 de 1961, mediante la cual se contemplaba la destitución de la tierra, manifestación de la herramienta de la expropiación, producto de la política del Frente Nacional de disminuir las diferencias sobre la tierra, para eliminar la violencia que dejó el bipartidismo. La "Alianza para el progreso", agenciada por Estados Unidos, buscó impedir que la izquierda comunista se aclimatara en América Latina, con ocasión del triunfo de la revolución cubana. Entonces, ayudó a los gobiernos del continente a que ejecutaran programas en favor de la redistribución de la tierra que aminoraran las diferencias sociales y el posible descontento popular que condujera a la aceptación de la izquierda, lo que permite explicar el surgimiento de organizaciones campesinas junto a los sindicatos, puesto que en ese momento se elevaban numerosas reivindicaciones, lo que explica la estrategia indígena de asociarse con este tipo de organizaciones para obtener el reconocimiento de la tierra. En el CRIC, según Galvis (2014), que se originaron procesos de aprendizaje de organizaciones campesinas y obreras, en el Cauca se creó el Sindicato del Oriente Caucano afiliado a la Unión de Trabajadores del Cauca -UTRACAUCA- y la Federación Agraria Nacional — FANAL-, como copia de procesos organizativos campesinos, que luego conformarían la cooperativa "Las Delicias".

En este contexto, la Ley 89 de 1890 reconoce el derecho a la tierra de los pueblos indígenas en los artículos 29 y 94. El articulo 29 incluía los territorios tradicionales y el 94 estipulaba la función del Instituto de Reforma Agraria, la potestad de otorgar a los resguardos tierras un beneficio de grupos indígenas que carecieran de estas, lo que permitía integrar un enfoque legal que buscaba chocar con la práctica violenta que desconocía su condición de personas, a pesar de ser una legislación que tenía por objeto modernizar el campo. Esta norma, que le dio 
esperanza a los indígenas para el reconocimiento de sus derechos a la tierra y a la diversidad cultural se utilizó en el apostolado de Quintín Lame a la defensa jurídica de los derechos de los pueblos indígenas y más tarde del CRIC.

Dos de sus artículos, inmersos en una copiosa legislación que pretendía disolver el latifundio improductivo, modernizar el agro y titular unidades familiares mediante el reparto de tierras y la colonización de baldíos, incluyeron dos importantes normas en favor de los pueblos indígenas: Artículo $29^{\circ}$. [...] no podrán hacerse adjudicaciones de baldíos que estén ocupados por comunidades indígenas o que constituyan su hábitat, sino únicamente y con destino a la constitución de resguardos indígenas. Artículo $94^{\circ}$. [...] El Instituto [de la Reforma Agraria] constituirá, previa consulta con el Ministerio de Gobierno, resguardos de tierras en beneficio de los grupos o tribus indígenas que no las posean. (Ley 135, 1961). La demanda de la aplicación de estas disposiciones, tal como lo pedía el punto cinco del programa de Lame, hizo posible el surgimiento en el departamento del Cauca, una región agobiada por el latifundio y los conflictos de tierras, del Consejo Regional Indígena del Cauca (CRIC), constituido en febrero de 1971 en el municipio indígena de Toribío (Sánchez, 2010, p. 19)

Entre 1966 y 1972, de acuerdo con Houghton (2008) se conformaron 74 reservas indígenas, cuya aceptación legal se dio en 1977. En este contexto, se ejerció una fuerte resistencia por las organizaciones indígenas de la región andina entre 1966 y 1978, que obtuvo la titulación de $8.71 \%$ de los territorios requeridos, lo que inició la resistencia por la tierra que tendría por objeto su recuperación, debido al rechazo estatal, mediane el accionar jurídico, de las pretensiones indígenas recuperar las tierras ancestrales en los años setenta.

\section{Creación y acción del derecho a la resistencia en el CRIC: 1971-1990}

El 24 de febrero de 1971, en Toribío, Cauca, de acuerdo con Galvis (2014) producto de la "Ley de Reforma Agraria", junto con las enseñanzas 
de Quintin Lame, de la Cacica Gaitana y de Juan Tama, se crea el Consejo Regional Indígena del Cauca (CRIC). Sin embargo su primer congreso se tuvo que postergar hasta septiembre por la persecución realizada por los terratenientes en la región.

Así que nosotros, en un análisis profundo en nuestra finca cooperativa con unos compañeros colaboradores, hicimos conocer nuestros Ocho Puntos del Sindicato en donde hablamos de que al indio tiene que ser respetado, oídas sus quejas al Estado y los demás puntos que teníamos, y de ahí sacamos los siete puntos que, para agilizar, llevamos a Toribío, donde los escribimos en la casita de La Susana, porque allí era el problema grave de los terratenientes... Y de ahí fue que comenzamos a hacer conocer a los Cabildos... Unos compañeros a Caldono y Jambaló, a mí me tocó a Tierradentro, a otros compañeros Coconuco, Puracé y Paniquitá... Y así, de esta manera, se organizó la Asamblea del 24 de Enero del 71 en Toribío... Eso fue el primer paso del Concejo Regional Indígena del Cauca, CRIC. Eso se dio a través de nuestro Sindicato Agrario de Las Delicias, de Guambia. (Bonilla, 2012, p. 142)

Los siete puntos acordados en este segundo congreso fueron: Recuperación de las tierras de los resguardos, ampliación de los resguardos, fortalecimiento de los cabildos, no pago del Terraje, publicidad y educación de las leyes indígenas, exigencia de su aplicación, defensa de la historia, la lengua y las costumbres indígenas, formación de profesores que propiciaran la educación en su propia lengua. Este último punto se relaciona con la defensa histórica de su cultura mediante la identificación simbólica del mundo de la vida que permite el uso común de un sistema de signos lingüísticos en una comunidad hablante, y también hace parte de la oposición realizada ante una política pública que atentó contra su cultura: La implementación del Instituto Lingüístico de Verano (ILV) institución estadounidense, perteneciente a la Universidad Rockefeller, que llegó a desarrollar su labor de evangelización lingüística con ayuda del gobierno. La introducción de la iglesia evangélica en el territorio caucano no tuvo otra finalidad que propiciar la división de los pueblos indígenas, atacando su cultura, tanto así que le enseñaban a las madres indígenas la manera 
"correcta" de educar a sus hijos, de cocinar, y se indujo a las mujeres indígenas a que se esterilizaran. El ILV impulsó, además, el proyecto de lo que sería el criticado "Estatuto Indígena". Ante las grandes dificultades que supuso la introducción del ILv, se destaca la imposición de una ideología individualista opuesta al régimen comunitario indígena, lo que llevaba a la destrucción del sentido de la vida de pueblos vinculados a la tierra.

Al mismo tiempo, la práctica religiosa de grupos evangélicos se ha visto asociada con préstamos de dinero, apoyo político de los partidos tradicionales y una obligación implícita de cambiar las costumbres indígenas, que dentro de la perspectiva de fortalecimiento organizativo comprende la puesta en duda de elementos centrales como la solidaridad y el comunitarismo sin los cuales la lucha por la tierra se debilita, como eje articulador de las luchas indígenas. (Unidad Indígena- citada por Gálvis, 2014, p. 87)

En 1972, el gobierno les propuso a los indígenas del CRIC que participaran en un censo, junto con el Dane, que permitiría contar la población indígena para conocer sus necesidades. Frente a la propuesta se dividieron las posiciones porque algunos se oponían a lo que consideraron que sería una estrategia contraproducente del gobierno para reconocerles sus territorios ancestrales. No obstante, terminó por concretarse este censo, que fue útil para los pueblos indígenas, porque les sirvió en sus procesos de organización política.

Haciendo este censo indígena, todos los dirigentes se pudieron desplazar a todas las comunidades, ya con una propuesta mucho más clara frente al objetivo de defender el territorio, entonces durante todo el día se trabajaba recogiendo el censo, y se iba citando a la gente en la noche en un sitio. Entonces, en la noche también se hablaba de la organización, se hablaba de la defensa de la autoridad indígena del territorio, y de una educación propia, de una economía más propia, en fin. (Morales 2009)

Debido a la presión ejercida por los terratenientes ante el gobierno, con ocasión de la reforma agraria y en el contexto de la organización sociopolítica por la reivindicación de derechos por distintos sectores, 
se firmó el Acuerdo de Chicoral en 1972; que derogó la anterior ley en la práctica, al permitir la creación de pactos en los que los terratenientes y el Estado se comprometieron a frenar la titulación y a reprimir militarmente la ocupación de tierras por los pueblos indígenas. Esto supuso la dificultad entre 1962 y 1972 de producir una redistribución territorial de las zonas baldías ubicadas en la selva y el llano, donde el $90 \%$ de la población que los habitaban eran pueblos indígenas, lo que afectaba profundamente su cultura y su vida como colectiva.

El pacto de Chicoral en enero de 1972 entre el gobierno, la Sociedad de Agricultores de Colombia (SAC) y Federación Colombiana de Ganaderos (FEDEGÁN) derivó en que el Estado retirara su apoyo a la Reforma Agraria, y por tanto, a la ANUC. (Gálvis, 2014, p. 106)

Una consecuencia directa de este pacto sobre el desarrollo de las organizaciones campesinas fue la división de la ANUC al encontrar limitada la fundamentación legal de la redistribución de la tierra lo que profundizó las diferencias entre las reivindicaciones de los campesinos y de los campesinos indígenas, pues, con el pacto, los únicos que tenían algún tipo de protección legal, Ley 89 de 1890, fueron los pueblos indígenas, lo que condujo a la ruptura de la alianza del CRIC con la ANUC. Otro factor relevante, según Galvis (2014), fue el respaldo de la izquierda maoísta a la ANUC, que derivó en los grupos de izquierda campesina en el país.

Las movilizaciones, como manifestaciones de resistencia, fueron desarrolladas por el CRIC, el Consejo Regional Indígena del Tolima (CRIT) y el Cabildo Mayor de San Andrés de Sotavento. Entre 1970 y 1980, se presentaron más de mil acciones de recuperación de tierras de campesinos e indígenas ubicados en los territorios del Cauca, Tolima, Córdoba, la Sierra Nevada, el Meta, Nariño y Valle, cuyo efecto de recuperación de la tierra no condujo a su legalización sino hasta finales de los ochenta con el reconocimiento de los resguardos coloniales.

El tercer congreso del CRIC, el 15 de julio de 1973 en Silvia, Cauca, contó con la participación de 4000 indígenas. En este congreso, se enfrentó la campaña de terror que se desató por la militarización del sector, cuyo propósito fue la discusión sobre la posibilidad de generar 
alianzas con la organización campesina ANUC para reivindicar la ley de Reforma agraria de 1961 y rechazar el Acuerdo de Chicoral. Una vez acordado esto, en el congreso, se dio el 16 de julio, procesos de intercambio con la ANUC, que continuaron el 17 de julio en una mesa redonda en Popayán convocada por la Facultad de Humanidades de la Universidad del Cauca.

En agosto de 1975, en Tierradentro, se produjo el cuarto congreso del CRIC, en el que se creó el periódico oficial "Unidad Indígena", que tuvo más tarde un papel protagónico en la comunicación, publicidad e intercambio nacional para la conformación de una organización nacional indígena. El periódico informaba sobre la realidad nacional, la postura y la actividad política que debían realizar los pueblos indígenas. Este periódico se preparaba en las reuniones de base, puesto que la información era relevante para la dirección de la organización. A pesar de esto, tuvo como dificultad en sus inicios que se escribía en español y no todos los indígenas dominaban la lengua, por lo que se generaban espacios internos de lectura y educación de la información que había allí., "Unidad Indígena" fue el antecedente de lo que sería el periódico regional "Unidad Álvaro Ulcué".

Esta línea de educación popular manifestaba las enseñanzas de Paulo Freire y de Orlando Fals Borda quien lideró la publicación "En defensa de mi raza", que publicitó el pensamiento y la obra de Manuel Quintín Lame. De acuerdo con García y Caballero (2012) la financiación inicial se hizo a partir de una donación realizada por la ONG inglesa “Survival International”, sección Francia. Este apoyo duró hasta 1982, cuando se crearía la ONIC y esta asumiría la continuidad del periódico. En las entrevistas realizadas sobre el periódico Unidad Indígena, por Judith García y Jorge Caballero a Edgar, líder indígena, se dice:

Subraya Edgar que: "En la medida que el periódico era un esfuerzo colectivo y no dependía de personas, su continuidad estaba garantizada, por lo menos en el Cauca, y posteriormente cuando la ONIC, se hizo cargo de éste. El periódico no nació para competir con nadie sino que surge como un compromiso revolucionario con una causa y como otra forma de hacer periodismo desde la base. En esa medida, era algo diferente que estábamos construyendo 
al fragor de la lucha y siempre ha sido un proceso inacabado y en permanente cambio. Todo ese espíritu subsistió y continuó en lo nacional y se transmitió al periódico regional, Unidad Alvaro Ulcué”. Era claro, nos explica, que “... el movimiento que empezaba a surgir se alejaba de los esquemas y doctrinas marxistas pero asumía el proceso en forma dialéctica, materialismo dialéctico, cuestionábamos la dictadura del proletariado y en esa manera éramos vistos como revolucionarios sospechosos y revisionistas lo cual era como colgarse en el cuello la espada de Damocles y por eso nadie trataba de controlarlo ni de apoderarse de él”. (García \& Caballero Fula 2012)

En el periodo de López Michelsen, 1974-1978, la preocupación por lo social y por la redistribución de la tierra fue dejada de lado, el costo de vida subió y el salario mínimo se mantuvo sin incremento, lo que condujo a la protesta social, hasta culminar en el paro cívico del 14 de septiembre 1977, en el que los pueblos indígenas participaron para reivindicar sus territorios. Esta fue una fecha destacada para la movilización social, por el contexto del país y por la alianza estratégica y solidaria entre sindicatos (CGT, UTC, CTC, CSTC), los estudiantes, las organizaciones sociales y populares y las organizaciones indígenas.

En 1978, bajo la represión militar contra los pueblos indígenas del Cauca, se produjo el v congreso del CRIC en Coconuco, Cauca, donde se creó el Programa Bilingüe Intercultural (PEBI), como respuesta al Instituto Lingüístico de Verano. Igualmente, se reflexionó sobre las violaciones a los Derechos Humanos hacia los indígenas con ocasión de la llegada de Pájaros a la región y dos atentados contra el dirigente del CRIC, Marco Avirama.

Es importante recordar que para la década de los años setenta y comienzos de los ochenta, en el Cauca la acción insurgente fue desarrollada especialmente por el M-19 y por las Farc-EP. En el marco de las políticas de democracia limitada emanadas del Frente Nacional (1958-1974), pero especialmente por las políticas establecidas por el gobierno de Turbay Ayala (1978-1982, el CRIC estableció relaciones con el M-19 y ello motivó la creación de una autodefensa armada a finales de los años ochenta, que se conoció 
como Movimiento Armado Quintín Lame (maql). (Gálvis, 2014, pp. 117-118)

En 1979, el presidente Turbay Ayala dictó su criticado "Estatuto de Seguridad" que consistió en 16 puntos en los que se agravaron las penas del Código Penal ante cualquier situación que alterara el orden público, lo que legitimó abusos por los militares contra la sociedad. A los pueblos indígenas se les acusó de pertenecer a grupos guerrilleros, acusación que trajo como efecto la alianza entre el M-19 y la Organización Indígena del Cauca en la construcción de mecanismos de defensa ante la violencia en su contra, lo que terminó en la creación del Movimiento Guerrillero Quintín Lame. El CRIC informa que:

En menos de un mes cae asesinado el dirigente Bejamín Dindicué, Ex vicepresidente del Comité Ejecutivo del CRIC; el 4 de febrero son detenidos y torturados por el ejército los dirigentes Marco Aníbal Avirama, presidente del Comité Ejecutivo y su Hermano Edgar Avirama, Taurino Nuscue, secretario del mismo Comité, su primo Miguel Ñuscue y Mario Escué Pasou, lo mismo que los colaboradores Luis Ángel Moroy, Graciela Bolaños y Guillermo Amórtegui, colaboradores constantes del movimiento. El norte y tierradentro han permanecido militarizados, creándose un clima de terror y hostigamiento en todo el campo. Ejército, policía y das realizan una verdadera cacería a los dirigentes de la organización, haciendo desaparecer a los detenidos por varias semanas y torturándolos como es el caso de Laurentino Aposta, Oscar Escué y Julián Zapata del resguardo de Huila, y de 14 indígenas detenidos en la vereda de La Bonita de Toribío. (CRIC1978 en Galvis 97)

En 1979 se elaboró un Estatuto Indígena por iniciativa del gobierno para mostrar una contrapartida en "favor" de los pueblos indígenas en materia de tierras, por lo que se le propuso al CRIC la creación de un departamento administrativo de asuntos indígenas y la creación de una legislación especial por el Presidente, para conferir facultades extraordinarias, lo que sin duda obligo a fuerte movilizaciones indígenas en oposición que hizo archivar la propuesta. 
El 03 de febrero de 1981, se cometió una masacre en Los Tigres, Resguardo en la Aurora por las Farc, que asesinaron a siete indígenas, entre ellos el líder indígena del norte del Cauca José María Ulcué, lo que determinó el distanciamiento por completo de los grupos guerrilleros del CRIC. El sexto congreso se desarrolló en este mismo año en Toribío, y confirmó un rechazo total al Estatuto indígena y al programa de Seguridad Nacional, que fueron los principales motivos de resistencia indígena en este periodo. Por ello, que se participó en el Segundo Paro Cívico Nacional en este año, pero allí no se logró el mismo efecto político dada la división de las centrales sindicales, lo cual fue duramente criticado en el congreso.

A estos hechos se añade el asesinato del sacerdote Álvaro Ulcué Chocué el 10 de noviembre de 1984. Este fue un líder indígena en la defensa de los pueblos indígenas, y su muerte es trascendental para la crisis de violencia que estaban viviendo los pueblos indígenas de esta época. De su obra, se tienen dos de sus cartas, en las cuales se manifiesta su liderazgo en la resistencia indígena. Es la carta del 30 de octubre de 1982, dirigida al expresidente Belisario Betancur, dice:

$¿$ Cree usted señor Presidente que con quitarle la tierra al indígena, que con tachar sus organizaciones, su cultura (costumbres propias, música, folclor, etc.), se le está abriendo paso al progreso del país? ¿Es acaso el indígena sinónimo de atraso y contaminación? ¿No es injusto que al indígena se le abandone en manos de la violencia? ¿O lo justo realmente es que sigamos indiferentes ante el exterminio de esta hermosa raza, de este pueblo, padre auténtico de este suelo colombiano? [...] No existe ningún respeto por la persona. Si supiera usted qué es "vivir" en medio del hambre, la inseguridad (asesinatos, secuestros, allanamientos en los hogares, propagación de intereses ideológicos que confunden al indígena, abuso de las mujeres, etc.), [la] falta de techo, salud, educación y bienes necesarios. Es por esto que vemos (y es lógico) que en estos hombres se vayan despertando sentimientos de agresividad y violencia, pues cuando no existe la ayuda y el apoyo, y se margina a las personas a condiciones de vida peores a la de los animales de nuestros "grandiosos zoológicos", las personas buscan los medios 
necesarios para lograr medio sobrevivir. Qué ironía tener que hacer injusticia para que se acabe la injusticia. Esto no es vivir (Ulcué, citado por Sánchez, 2010, 277-278)

Entre 1970 y 1980, se recuperaron tierras por los Pueblos indígenas andinos, y se legalizaron 405000 hectáreas en favor de los resguardos indígenas del Cauca, el Tolima, Córdoba, Caldas y Nariño. Sin embargo, el contexto de persecución por distintos actores armados, la represión por el Estado y la eliminación de la política inicial del Incora en el reconocimiento de la tierra para los pueblos indígenas produjo una grave crisis en el CRIC, lo que condujo a la necesidad de replantear una organización nacional, que buscara el diálogo con todos los pueblos indígenas de Colombia, lo que condujo a la conformación de la ONIC, sin que ello implicara cerrar el CRIC, sino que el contexto requirió una organización nacional que pasara de una lucha regional a una lucha nacional indígena de reivindicación.

\section{Creación de la ONIC}

De acuerdo con la ONIC, el instrumento que cumplió un rol relevante en la visibilización de la vulneración de los derechos humanos en este periodo a nivel nacional e internacional y que a su vez condujo a la necesidad de la unión de los pueblos indígenas colombianos fue el periódico Unidad indígena, liderado por Trino Morales.

Entonces en al año 80 me dediqué totalmente a esa tarea: organizar primero una coordinadora y después crear una organización nacional. Con ese propósito me fui voltiando por todo el Cauca, por toda la Sierra Nevada, por donde los kunas de Antioquia, estuve en el Vichada, en el Vaupés y no sé más... Ese trabajo se hizo en el apoyo del CRIC. El CRIC pagaba los viajes, el transporte y la estadía. Es un valor muy importante que se tiene que reconocer al CRIC a las organizaciones internacionales. Ellas han apoyado oportunamente, porque sin su aporte no habríamos podido. Es que los viajes son muy costosos. Es muy costoso traer, por ejemplo, del Vaupés unas cinco personas, primero en bote y después en avión. O venir de la Sierra a Bogotá en un carro. Por eso se pudo 
hacer gracias al aporte que solicitamos en Europa. La represión fue eficaz, podríamos decir. Tuvo un efecto, inesperado, porque obligó a que las organizaciones internacionales conocieran la pelea de nosotros y nos apoyaran. (Gross, citado por Gálvis, 2014, 121)

El hecho de sacar a la luz pública y denunciar ante la comunidad nacional e internacional los atropellos que a diario vivían los indígenas en Colombia, hizo que el periódico "Unidad Indígena", órgano oficial del CRIC, fuera el vocero para la visibilizar las necesidades, amenazas y vulneración de los derechos de los pueblos Indígenas. Su director, Trino Morales, indígena Guambiano, quien desde 1963 venía liderando procesos de recuperación territorial de su pueblo, fue el encargado por el CRIC, para trabajar en la ONIC.

El 12 de octubre de 1980, en Coyaima, Tolima, se produjo el primer encuentro nacional indígena de Colombia que contó con la presencia de 1500 indígenas. Allí, se acordó la consolidación de una Coordinadora Nacional indígena, que tuvo como tarea la creación de la Organización Nacional Indígena de Colombia (ONIC). Su institucionalización se realizó en la localidad de Bosa, en Bogotá, en febrero de 1982. Se reunieron 2500 indígenas en representación del $90 \%$ de los pueblos indígenas de Colombia. El Primer Congreso Indígena Nacional adoptó para la ONIC los principios de Unidad, Tierra, Cultura y Autonomía que expresaban las líneas de acción de la organización. El congreso definió líneas de acción respecto a la Legislación Indígena y el cumplimiento del estado de la Ley 89 de 1890, y recomendó a todos los indígenas del país el fortalecimiento de la autonomía indígena y de rodear a las autoridades tradicionales para el ejercicio de su gobierno.

En 1988, dada la declaración Internacional de los Derechos Humanos y el auge de la protección del medio ambiente, surge el Decreto 2001 que introduce el elemento diferencial en la reivindicación de la titulación de la tierra en forma de resguardos cuya definición toma dos sentidos: uno jurídico y otro político. Jurídicamente se comprenden el resguardo como: "Institución legal y sociopolítica de carácter especial, conformada por una comunidad indígena, con título de propiedad comunitaria que posee un territorio y se rige por él, en el manejo de la vida interna por la cultura indígena” (Houghton, 2008, p. 85). 
Mientras que políticamente se define como "el carácter colectivo de la propiedad" (Houghton, 2008, p. 85).

En la década de los noventa, se presenta la coyuntura social por la defensa de la identidad indígena y de la diversidad de lo local, bajo la conmemoración del V Centenario del "Descubrimiento de América", la creación del zapatismo en Chiapas en México, con el lema de la reivindicación de "la larga noche de los 500 años" con ocasión de la introducción del TLC con México, Estados Unidos y Canadá y la conformación de la Asamblea Nacional Constituyente para crear una nueva Constitución y Ratificar el Convenio 169 de la OIT, se planteó la posibilidad de reivindicar la identidad cultural de los pueblos indígenas y de pasar de una justicia del reconocimiento a una justicia redistributiva que permitiera devolver a los pueblos indígenas los territorios ancestrales.

Según Houghton (2008), antes de la Constitución del 91, se había obtenido un logro territorial de las luchas indígenas por la tierra, que consistió en que cerca del $80 \%$ de los territorios indígenas fueran titulados, lo que corresponde a un $44.91 \%$ en el gobierno de Barco y un $25.95 \%$ en las administraciones de Betancur y de Turbay, y el $9.14 \%$ en periodos anteriores a estas administraciones.

\section{Constitución de 1991: tierra, autonomía y cultura}

En 1988, empieza el proceso constituyente con ocasión de la desmovilización del Movimiento 19 de abril, M-19, al convocarse a un plebiscito que es declarado inconstitucional por el Consejo de Estado, lo que conduce a la necesidad de crear una Asamblea Nacional Constituyente, que fue lanzada por los estudiantes, para instituir una nueva Carta Política, lo que se concreta en el movimiento de la séptima papeleta de 1990.

En este proceso de cooperación colectiva, hizo parte la ONIC en las mesas de trabajo de varios territorios del país, y se reúne el “Tercer congreso de la ONIC", donde se definieron las propuestas de integración constitucional: "Las propuestas de interés nacional (democracia, derechos humanos, ecología, fuerza pública) y las propuestas referidas a lo indígena (país multiétnico, grupos étnicos, autonomía territorial, identidad cultural, propiedad colectiva de la 
tierra)" (ONIC, 1995, p. 25). También se decidió que el representante que participaría en la constituyente fuera Francisco Rojas Birry, indígena embera, a nombre de la ONIC, bajo la consigna: "Por nuestras Raíces y los Sueños de Todos". Este indígena, posteriormente, apoyaría la causa indígena como constituyente en compañía de Lorenzo Muelas Hurtado, del movimiento regional Autoridades Indígenas del Suoccidente Colombiano (AISCO) y de Alfonso Peña Chepe, del Movimiento indígena Quintín Lame.

La ONIC produjo, en noviembre de 1990, una propuesta de cinco puntos, titulada "La Colombia que Queremos", que plantea un reconocimiento de la participación democrática y pluralista, el respeto por los derechos humanos, las garantías de justicia y paz, la protección del medio ambiente, el desarrollo económico. Sin embargo, al expresarse una representación de la diversidad étnica y cultural, era necesario elaborar una propuesta que integrara los movimientos indígenas, negros y raizales bajo la consigna: Tierra, Autonomía y Cultura.

Tanto los indígenas como los negros y los raizales hemos sido pueblos históricamente excluidos, desconocidos y discriminados; hemos sufrido el saqueo violento de nuestros territorios o se nos ha desplazado con medidas económicas, sociales y militares; nuestros lugares de asentamiento coinciden con el mapa de la pobreza, y nuestras culturas han sido sometidas a la persecución y a políticas integracionistas, en nombre de la cultura occidental, de un dios o de la soberanía nacional. De ahí que en permanente contacto con las organizaciones negras y raizales nuestras propuestas a la Asamblea Nacional Constituyente consistieron en primer lugar en "el reconocimiento del carácter multiétnico y pluricultural del pueblo colombiano".

[...] El principal derecho a reivindicar por Indígenas, raizales y negros fue el de la propiedad sobre la tierra, indispensable para nuestra supervivencia física y cultural, indispensable para nuestra supervivencia física y cultural, y también para la preservación de ecosistemas tan frágiles como la Sierra Nevada de Santa Marta, la Amazonía, el Archipiélago de San Andrés y la cuenca del Pacífico, y en general de nuestros hábitats actuales. 
Pero nuestros derechos van enlazados unos con otros y por tanto nuestra pelea es por el conjunto de ellos. Nada logramos si, a la vez que recuperamos los territorios, no tenemos autonomía para vivir en ellos, o sea, la capacidad que tiene un pueblo para definir y responder a las necesidades que tengan que ver con su vida cultural, económica, política, religiosa y social. Por tanto, era necesario que la Constitución reconociera el derecho de nuestros pueblos a desarrollarse económica y socialmente, con las autoridades propias y preservando nuestra identidad. (ONIC, 1995, pp. 29-30)

En el desarrollo de las comisiones constitucionales, en la comisión primera participó Francisco Rojas Birry, donde se determinarían los principios y los derechos y en la comisión segunda Lorenzo Muelas y Alfonso Peña Chepe, sobre ordenamiento territorial. Las propuestas de los representantes indígenas tuvieron una fuerte recepción durante el primer debate, pero en el segundo debate, algunas de ellas fueron negadas. De acuerdo con la ONIC (1995), los representantes indígenas manifestaron su descontento y la posibilidad de retirarse de la Asamblea si no se reconocía en la constitución la propiedad sobre la tierra, ni el derecho a la autonomía territorial, afirmados en la Ley 89 de 1890, lo que suscitó un conflicto de dos días entre los constituyentes, y el último día se aprobaran las “entidades territoriales indígenas".

De esta manera, la Constitución de 1991 instituyó un cambio en la perspectiva integracionista del país, al reconocer la diversidad étnica y cultural como uno de los principios rectores del Estado Social de Derecho en el preámbulo, y en los artículos 7, 8 y 10, que instituyen la obligación del Estado de proteger y garantizar la cultura y las lenguas indígenas, como expresión de la diversidad y como riqueza de la nación. Instituye los derechos y la libertad, la igualdad y la propiedad colectiva de la tierra de los grupos étnicos, las tierras de los resguardos, el acceso a la cultura en la construcción de la identidad nacional.

Se destaca el artículo 70, en el que el Estado reconoce la igualdad y la dignidad de todas las culturas que conviven en el país. El artículo 72 reconoce en el patrimonio cultural de la nación el patrimonio arqueológico junto con los bienes que conforman la cultura y la identidad nacional. Estos bienes se definieron como inalienables, inembargables 
e imprescriptibles, por lo que cede la potestad legislativa y reglamentaria al Congreso de la República para los territorios que constituyan una riqueza arqueológica.

En el artículo 246, se otorgan funciones jurisdiccionales a las autoridades de los pueblos indígenas, respetando los procedimientos establecidos bajo sus usos y costumbres, siempre y cuando no vayan en contravía del orden institucional y legal. La Constitución desarrolla un enfoque integracionista que resalta la necesidad de proteger la cultura, al entenderla como uno de los elementos fundamentales para constituir y comprender la identidad nacional. Según este principio, se ubica la protección de los pueblos indígenas, los resguardos, los territorios, el respeto por su cultura, sus usos, sus costumbres y sus tradiciones. Este mandato produce un marco jurídico de justicia, territorio y soberanía. Sin embargo, dicha labor queda supeditada a una ampliación legal. En el artículo 68 se introduce la obligación de la educación de los grupos étnicos con el respeto y el desarrollo de su identidad cultural.

En los artículos 329 y 330, se formula una diferencia entre entidades territoriales indígenas, resguardos indígenas y territorios indígenas. El artículo 329 formula que son las entidades territoriales indígenas las que tendrán los derechos sobre los territorios indígenas, por lo que su conformación será establecida por la Ley Orgánica de Ordenamiento Territorial, que será elaborada por el gobierno nacional y los representantes de las comunidades indígenas. Mientras que los resguardos indígenas son considerados como propiedad colectiva inajenable.

Los territorios indígenas se encuentran regulados en el artículo 330. Serán administrados por consejos, cuya estructura se ajustará a la costumbre de cada comunidad. Los consejos tienen las siguientes funciones: aplicar la legislación sobre el uso del suelo y su habitación, elaborar las políticas y planes de desarrollo económico y social en concordancia con el Plan Nacional de Desarrollo, impulsar las inversiones públicas sobre sus territorios, recibir y distribuir los recursos, proteger la riqueza natural, organizar los proyectos propuestos por las comunidades de su territorio, acompañar el sostenimiento del orden público en su territorio, de acuerdo con las medidas que dicte el Gobierno Nacional, representar su territorio frente a la administración nacional junto con las que le determine la Ley. 
Los recursos naturales y su explotación aparecen regulados en el parágrafo del artículo 330, donde se establece que deberá realizarse esta práctica sin perturbar la "integridad cultural, social y económica de las comunidades indígenas". Aparece la figura de la consulta previa como deber del Gobierno, que consiste en promover la participación de los representantes de las comunidades indígenas en las decisiones que se tomen sobre la explotación de los recursos naturales en los territorios de estos pueblos. Igualmente, se reconoció el derecho a la jurisdicción especial indígena en su territorio con el artículo 171, así como la representación política, y se les otorgan dos puestos en el Senado de la República y en la Cámara de Representante (art. 171 y 176). Junto con el derecho a la doble nacionalidad, en el caso de pueblos indígenas fronterizos (96).

\section{Los efectos de la Constitución de 1991 sobre los pueblos indígenas}

A pesar de desarrollarse un proceso de participación política en el que la renovación del Estado propició un cambio jurídico, social y cultural de reconocimiento de los derechos de los pueblos indígenas, la persecución y el régimen del terror continuó, expresado en la Masacre del Nilo en diciembre de 1991 en Caloto, Cauca, ocurrida 6 meses después de la expedición de la Constitución de 1991, donde se produjo el asesinato de 20 indígenas paeces:

Seis meses después de adoptada la nueva Constitución Política de 1991, en la que por primera vez se reconocieron los derechos colectivos de los pueblos originarios, en particular la consideración constitucional que "Las tierras comunales de grupos étnicos y las tierras de resguardo son inalienables, imprescriptibles e inembargables (artículo 63)", se hizo evidente la contradicción entre el Estado formal y el Estado criminal. El 16 de diciembre de 1991, una comunidad de indígenas nasa (paeces) en el Norte del Cauca, del Resguardo de Huellas, fue convocada por terratenientes en la Hacienda El Nilo para tratar de "resolver por la vía del diálogo" la ocupación de unas tierras que los indígenas poseían 
ancestralmente, pero sobre las cuales el Estado de manera irregular había extendido títulos de propiedad a un clan de mafiosos. Los indígenas se congregaron esperanzados para escuchar la oferta que se les haría, la cual no era otra que una emboscada en la que se masacró a veinte personas entre ellos líderes, ancianos, mujeres, niñas y niños; se les quemaron sus casas, se les desplazó y despojó violentamente. La comunidad indígena fue masacrada por que defendía sus derechos. Inmediatamente se demostró que los mafiosos no habían actuado solos y que contaron con el apoyo del jefe paramilitar Fidel Castaño y oficiales de la Policía Nacional, entre ellos, el Capitán Fabio Alejandro Castañeda Mateus y el mayor Jorge Enrique Durán Argüelles. (Cajar, 2014)

De acuerdo con la ONIC, no solo se trató de la Masacre del Nilo sino también de la persecución contra la organización indígena con los asesinatos ocurridos en la Sierra Nevada de Santa Marta

de Luis Napoleón Torres y Hugues Chaparro, líderes arhuacos, en diciembre de 1990, en pleno proceso constitucional. A esto, se añaden los homicidios de líderes indígenas del Tolima como Alfonso Timoté Tique, Cacis, Cupitra, Villabón Ducuara y Angelmiro Madrigal. En 1992, en San Andrés de Sotavento, la ejecución de Gerardo Moreno, en Moracazo, Sierra Nevada de Gregorio Nieves y en el Putumayo de José Homero Mutumbajoy. En 1993 los cuatro asesinatos de Manuel Narciso Suárez, fiscal del cabildo indígena de El Volao (Necoclí, Antioquia), muerto el 2 de octubre; Nelson Moreno, concejal de Ortega, Tolima; Jorge Varga, gobernador suplente del cabildo de Paletará (Puracé, Cauca), muerto el 6 de noviembre. Francisco Mujica, líder Arzario de la comunidad de Guamaka, Sierra Nevada de Santa Marta. (ONIC, 1995, p. 58)

Este contexto de graves violaciones a los derechos de los pueblos indígenas se acompañó de iniciativas legislativas que se convirtieron, en palabras de la ONIC (1993), en "La principal amenaza a los derechos indígenas”. Se trataba del Proyecto de Ley General de Educación, que elimina el derecho al 
reconocimiento de los procesos educativos propios de las comunidades, la selección de maestros por las comunidades, la elaboración de los currículos desde las comunidades, la excepción de títulos y otros requisitos a los maestros indígenas y la gratuidad de toda la educación que se imparte a indígenas. (ONIC, 1995, p. 58)

Estos derechos estaban contemplados, antes de la Carta Política de 1991, en El Decreto 1142 de 1978, la Resolución 3454 de 1984, el Decreto 2230 de 1986 y el Decreto 1217 de 1987 (este último derogado por la Ley 115 de 1994).

Se reitera esta amenaza con el Proyecto de Ley de Regalías que deroga los artículos 129 y 132 del Código de Minas de 1988, cuando se logró exonerar el pago de impuestos para la explotación de minas en su territorio, así como la obligación de los municipios de otorgar recursos en obras y servicios que beneficien a las comunidades indígenas por la explotación de minas y petróleo en su territorio. También se obvió el precepto constitucional que reconoce a los territorios indígenas como entidades territoriales que permite la recepción de recursos proveniente de los impuestos.

La ONIC (1993) denuncia también el proyecto de Ley que crea el Ministerio del Medio Ambiente que no reconoce el aporte de los indígenas a la protección del Medio Ambiente, y tampoco la autoridad de los Cabildos en los resguardos, ni la propiedad de las tierras de los resguardos, se permite la desintegración de los resguardos al afirmar la figura de la expropiación, no reconoce los usos y las costumbres de las comunidades indígenas en sus principios normativos, y dispone el control de los recursos en cabeza de la CAR sin participación indígena.

Finalmente, se acusa el Proyecto de Ley Orgánica de ordenamiento Territorial, debido al reconocimiento del autogobierno de los pueblos indígenas en la constitución como entidades territoriales, pero para su desarrolló se dictó la necesidad de establecer un proceso de participación con los indígenas que sería verificable en la Ley Orgánica de Ordenamiento Territorial. Bajo esta disposición, se produjo entre 1992 y 1993 una consulta a los pueblos indígenas con el fin de presentarla ante el Congreso de la República. 
Sin embargo, el Gobierno le presentó al Congreso el proyecto de Ley Orgánica de Ordenamiento sin el componente indígena, con lo que descuaderna el país con una ley a medias, vulnera los derechos constitucionales de los indígenas y desconoce los acuerdos a que había llegado con las organizaciones indígenas. (ONIC, 1995, p. 60)

Con esta ley, se produjo un vació jurídico hasta la actualidad.

En este escenario, se consolida la regulación legal de la creación de asociaciones de Cabildos y Autoridades Tradicionales Indígenas en el Decreto 1088 del 10 de junio de 1993, que fue el producto de la obligación constitucional de crear una norma relacionada con los territorios indígenas de manera temporal. Mientras se redactaba la Ley de Ordenamiento Territorial, dado el vacío presentado ante el Congreso y la presión ejercida por las comunidades indígenas, se requirió la elaboración de un estatuto legal que les permitiera asociarse y participar en los procesos de desarrollo económico, social y cultural del país, mediante asociaciones que permitieran la representación de los cabildos y las autoridades indígenas en la participación de los procesos que tuvieran por objeto desarrollar las comunidades indígenas, con personería jurídica, autonomía administrativa y patrimonio propio. Para conformar este tipo de asociaciones se determinó como requisito el consentimiento favorable de los miembros de la comunidad, atendiendo a sus usos y costumbres, el cual se ostentará por escrito por el Cabildo o la Autoridad tradicional indígena, su máxima autoridad será una asamblea. La regulación del Cabildo debía estar contenida en los estatutos, que serían elaborados por ellos mismos y deberían registrarse en "la Dirección General de Asuntos Indígenas" de la Alcaldía.

Finalmente, la Ley que creó el Ministerio del Medio Ambiente (Ley 99 de 1993) reconoció la biodiversidad del medio ambiente y la necesidad de introducir el desarrollo sostenible en las políticas de desarrollo estatal, definiéndolo como:

Del concepto de desarrollo sostenible: se entiende por desarrollo sostenible el que conduzca al crecimiento económico, a la elevación de la calidad de la vida y al bienestar social, sin agotar la base de recursos naturales renovables en que se sustenta, ni deteriorar 
el medio ambiente o el derecho de las generaciones futuras a utilizarlo para la satisfacción de sus propias necesidades. (art. 3)

Con esta disposición, introduce el concepto de protección ambiental para generaciones futuras, reconocido a nivel internacional, como componente indígena, pero prácticas, costumbres e imaginarios de los pueblos indígenas en la construcción del desarrollo no aparecieron, tal como lo había denunciado la ONIC.

En el artículo 76, se afirma que la explotación de los recursos naturales debe tener en cuenta la no afectación de la integridad cultural, económica y social de las comunidades indígenas y de los pueblos afrodescendientes, a los cuales se les deberá elevar la consulta previa sobre las decisiones en materia ambiental y que sean de su interés, en cumplimiento de la Ley 70 de 1993 y del artículo 330 de la Constitución, lo que introduce la obligación de ratificacr el Convenio 157 de la OIT sobre la consulta previa, sin que ello significara reconocer la autodeterminación de su territorio, tal y como lo contempló la constitución, ya que esta figura implica un reconocimiento a la participación ciudadana y no un derecho de veto.

Esta vulneración a los derechos de los pueblos indígenas que ya se habían reconocido en la Carta Política, bajo el emblema empleado en la constituyente de autonomía-tierra-cultura, buscó ser coherente con la visita de Rigoberta Menchú a Colombia y disminuir el desconocimiento de los derechos de los pueblos indígenas con la expedición de la Ley Orgánica de Ordenamiento Territorial (Ley 388 de 1997), y con la creación del Ministerio del Medio Ambiente al ratificar el "Convenio Constitutivo del Fondo para el Desarrollo de los Pueblos Indígenas de América Latina y el Caribe" mediante la Ley 145 de 1994, que busca amparar las vías que permitan el autodesarrollo de los pueblos, comunidades y organizaciones indígenas en América Latina y el Caribe, mediante un "Fondo Indígena”, que tendrá tres funciones:

a) Proveer una instancia de diálogo para alcanzar la concertación en la formulación de políticas de desarrollo, operaciones de asistencia técnica, programas y proyectos de interés para los Pueblos Indígenas, con la participación de los Gobiernos de los Estados de la región, Gobiernos de otros Estados, organismos 
proveedores de recursos y los mismos pueblos indígenas; b) Canalizar recursos financieros y técnicos para los proyectos y programas prioritarios, concertados con los Pueblos Indígenas, asegurando que contribuyan a crear las condiciones para el auto desarrollo de dichos pueblos; c) Proporcionar recursos de capacitación y asistencia técnica para apoyar el fortalecimiento institucional, la capacidad de gestión, la formación de recursos humanos y de información y así mismo la investigación de los Pueblos Indígenas y sus organizaciones”. (Congreso de Colombia, 1994)

Se implanta en estos procesos de desarrollo la posibilidad de comprender, en un marco de diversidad cultural, la inclusión de la etnoeducación mediante el Decreto 804 de 1995, con la participación social y ciudadana en la construcción de este marco educativo, lo que continúa la democratización de la educación con principios como: Integridad, diversidad lingüística, autonomía, participación comunitaria, interculturalidad, flexibilidad, progresividad y solidaridad.

En el final de la década de los noventa y el principio del nuevo siglo se han deteriorado los derechos de los pueblos indígenas ya reconocidos por la Constitución y conquistados mediante la resistencia indígena, bajo el pretexto de la adecuación interna del Estado para la aplicación de una Constitución que reconoció la autonomía del territorio de los pueblos indígenas, que afirmó el pluralismo jurídica pero que, en su desarrollo, se ha desvirtuado, masacrando los derechos que permitieron la vida de los pueblos indígenas, tal como lo realizó la acción militar en la masacre del Nilo y de los constantes asesinatos de líderes indígenas. Estas acciones han hecho vana la visita de Rigoberta Menchú y el Convenio Constitutivo del Fondo para el Desarrollo de los Pueblos Indígenas de América Latina y el Caribe, que se nombró como "Voces de la tierra; pueblos indígenas, nuevos socios; el derecho de autodeterminación en la práctica”. En este Congreso, la ONIC presentó un documento de denuncia internacional por la vulneración de los derechos de los indígenas colombianos. El Congreso fue coordinado por el Centro Holandés para los pueblos indígenas, desarrollado en Amsterdam entre el 10 y el 11 de noviembre de 1993. 
Con ocasión del vacío constitucional en el que se determinó la materialización del derecho a la tierra y la autoderminación de los pueblos indígenas en un proceso de concertación que se reflejaría en la Ley orgánica de ordenamiento territorial, cuyo proceso de consulta con 45 artículos que recogen lo que debería ser una regulación legal para los indígenas, pero que nunca se llevó al Congreso y más bien se presentó un proyecto de ley que no incluía el componente indígena. En esta forma, se observa el desinterés del Estado por concretar una justicia político-económica para los pueblos indígenas encubriendo su injusticia en una aparente justicia cultural mediante políticas de etnoeducación o de autodesarrollo cuya eficacia es nula.

Pues bien, el Gobierno presentó a finales de 1992 al Congreso Nacional el Proyecto de Ley Orgánica, sin espera que terminara la consulta indígena. El Congreso le devolvió el proyecto, siendo presentado de nuevo por el gobierno en septiembre de 1993, pero no incluyó el capítulo referente a los Territorios Indígenas, pese a que el Ministerio de Gobierno tenía ya sobre el escritorio la propuesta surgida de la consulta a los indígenas. Desde entonces le hemos solicitado insistentemente al Gobierno adicionar aquel Proyecto de Ley con nuestras propuestas, pero el Ministerio dilata cada vez una respuesta, pospone las reuniones y no responde a los congresistas indígenas.

La situación se acaba de tornar más compleja, porque el viernes 05 de noviembre asesinaron al Senador ponente del Proyecto de Ley Orgánica de Ordenamiento territorial, ambiente de violencia que hace más urgente la solidaridad internacional. En estas circunstancias, la presencia de la ONIC en este Congreso, que busca fortalecer la experiencia de autodeterminación de los pueblos indígenas, tiene definidos tres objetivos: 1) Compartir el proceso de Ordenamiento Territorial en que estamos comprometidos los indígenas en Colombia con otros pueblos indígenas del mundo, [...] 2) Denunciar la actitud del Gobierno colombiano, por su negativa recurrente $[\ldots]$ y 3) Reconocer el apoyo prestado por la Comunidad Europea al proceso de consulta sobre ordenamiento territorial indígena, al tiempo que solicitamos la solidaridad 
de la comunidad internacional para que llegue a feliz término nuestra experiencia de autonomía. (ONIC, 1993, 3-4)

La dilatación del reconocimiento práctico y material de la autodeterminación y del derecho a la tierra de los pueblos indígenas se reitera con la expedición de la Ley 160 de 1994, que una vez más desconoce los derechos que los pueblos indígenas habían logrado en sus luchas de más de un siglo. En los años sesenta lograron modificar la Ley 135 de 1961, quintando el poder que tenía el Estado en la destitución territorial con el fin de una redistribución que asumió durante la década de los años setenta el reconocimiento y la titulación de la tierra para los pueblos indígenas, otorgando como función al Incora de manera unilateral, sin disponer de la participación de los pueblos indígenas, el estudio de las necesidades de tierras de las comunidades indígenas y la conformación, ampliación, saneamiento y reestructuración de los resguardos.

La reglamentación de la Ley 160 de 1994 se realizó mediante el Decreto 2164 de 1995, que impuso como como obligación del Instituto Colombiano de la Reforma Agraria, Incora, el desarrollo de estudios que permitieran ubicar las necesidades de tierras de las comunidades indígenas, con el fin de titular las tierras que estos grupos requieran para su desarrollo. por lo que esta disposición administrativa proporciona procedimientos especializados para reconocer los titulos y ampliar su territorio, siempre y cuando no generen perjuicios a las comunidades negras. Para el desarrollo de esta labor, esta norma establece definiciones específicas sobre los conceptos de: territorios indígenas, comunidad indígena, reserva indígena autoridad tradicional y cabildo indígena ${ }^{6}$.

6 Artículo $2^{\circ}$. Definiciones. Para los fines exclusivos del presente Decreto, establécense las siguientes definiciones: Territorios Indígenas. Son las áreas poseídas en forma regular y permanente por una comunidad, parcialidad o grupo indígenas y aquellas que, aunque no se encuentren poseídas en esa forma, constituyen el ámbito tradicional de sus actividades sociales, económicas y culturales. Comunidad o parcialidad indígena. Es el grupo o conjunto de familias de ascendencia amerindia, que tienen conciencia de identidad y comparten valores, rasgos, usos o costumbres de su cultura, así como formas de gobierno, gestión, control social o sistemas normativos propios que la distinguen de otras comunidades, tengan o no títulos de propiedad, o que no puedan acreditarlos legalmente, o que sus resguardos fueron disueltos, divididos 
La Ley 160 de 1994 de reforma agraria empezó a poner límites a la titulación, saneamiento, ampliación y reestructuración de resguardos indígenas utilizando para estos el término de "superficies” en lugar tierras. Con esta designación se buscaba restringir la propiedad ancestral de las comunidades sobre los recursos naturales existentes en sus territorios, propiedad que es subsidiaria a la propiedad de la tierra. Con esta Ley comenzó también la cuenta regresiva de la reforma agraria como política redistributiva de la tenencia de la tierra, a la cual le puso un plazo perentorio de 14 años. (CECOIN, 2009, p. 9)

Como resultado de esta ley y su decreto respectivo, se vive un mercado de tierras que termina por destruir las tierras de los campesinos, máscara de intervención de los agentes privados bajo la búsqueda de políticas que tienen por objeto el bien común. Solo el $20.46 \%$ de los territorios indígenas fueron legalizados con ocasión del cambio constitucional que, a pesar de su relevancia, no fue superior a las décadas anteriores cuando se logró cerca del $80 \%$ de la legalización de la tierra a favor de los indígenas con ocasión de la movilización indígena.

La expedición del Decreto 1397 de 1996 para la creación de la Comisión Nacional de Territorios Indígenas y la Mesa Permanente

o declarados vacantes. Reserva indígena. Es un globo de terreno baldío ocupado por una o varias comunidades indígenas que fue delimitado y legalmente asignado por el Incora a aquellas para que ejerzan en él los derechos de uso y usufructo con exclusión de terceros. Las reservas indígenas constituyen tierras comunales de grupos étnicos, para los fines previstos en el artículo 63 de la Constitución Política y la Ley 21 de 1991.Autoridad tradicional. Las autoridades tradicionales son los miembros de una comunidad indígena que ejercen, dentro de la estructura propia de la respectiva cultura, un poder de organización, gobierno, gestión o control social. Para los efectos de este Decreto, las autoridades tradicionales de las comunidades indígenas tienen, frente al Incora, la misma representación y atribuciones que corresponde a los cabildos indígenas. El Cabildo Indígena es una entidad pública especial, cuyos integrantes son miembros de una comunidad indígena, elegidos y reconocidos por ésta, con una organización socio política tradicional, cuya función es representar legalmente a la comunidad, ejercer la autoridad y realizar las actividades que le atribuyen las leyes, sus usos, costumbres y el reglamento interno de cada comunidad. 
de Concertación con los pueblos y organizaciones indígenas se consolida con el fin de propiciar acuerdos que permitan la constitución, ampliación, reestructuración y saneamiento de los territorios de los pueblos indígenas, pero, a pesar de su creación no se aplicó durante dos años. Fue hasta la expedición del Decreto 1320 de 1998 que reguló la Consulta Previa, cuando se dio su aplicación.

La inclusión en el ordenamiento jurídico colombiano de la Consulta previa nunca se efectuó con los pueblos indígenas, ni con las comunidades negras pero, a pesar de estar en contravía de lo dispuesto en la Declaración 169 de la OIT, esta entró en vigencia. Se definió la “Consulta Previa” como el examen del impacto social, económico, ambiental y cultural que se pueda generar con la exportación de estos recursos, con el fin de disminuir el impacto negativo que se pueda ocasionar, para proteger a estas comunidades. Se extiende el Derecho a la consulta previa a los pueblos que no poseen el título del territorio que habiten, siempre y cuando se mantengan habitándolo regular y permanentemente.

En el ejercicio de la instrumentalización de la Consulta Previa en el discurso de la cultura y del desarrollo sostenible, se observa que, en el caso de que uno de los pueblos se oponga, la simple oposición no ocasiona un Derecho al Veto, sino que será la autoridad ambiental quien determinará la entrega o rechazo de la licencia sujeta a posibles planes de "impacto ambiental, social y cultural" que permitan disminuir los daños, mediante un examen que medie entre bien común y bien particular, siendo la autonomía de los pueblos indígenas un bien particular. Una vez más, se postergó la inclusión de la Ley de Ordenamiento territorial en favor de los pueblos indígenas, con la que se contaba con su participación para el reconocimiento material de la tierra y el ejercicio de su autodeterminación y con ello su cultura. Con estas disposiciones, se manifiesta la relación expuesta por Fraser (1997), al plantear la congruencia entre reconocimiento y redistribución para su eficacia material, en este caso, la redistribución de la tierra para el reconocimiento de la autodeterminación de los pueblos indígenas, lo que da continuidad a la tutela, puesto que es un organismo externo a estos quien, de manera unilateral, estudia y decide el reconocimiento de los resguardos indígenas. 


\section{Las mingas indígenas: por la tierra, contra la violencia}

En 1997, el Cauca es azotado por la violencia entre los paramilitares, grupos guerrilleros, el ejército, el narcotráfico y la delincuencia común, y en este escenario se constituyó el x Congreso Regional Indígena del Cauca, que reflexionó sobre este contexto y el efecto de la división en la Organización Indígena. Para lograr la unión, utilizaron la estrategia de fortalecer los Cabildos como respuesta ante la violencia, lo que acentuó el discurso de la identidad étnica, mediante la cual se opusieron a los grupos armados. Esta perspectiva es continuada en 1999 con la búsqueda de procesos de paz para lograr la defensa de la cultura, la autonomía y el territorio de los pueblos indígenas:

Aunque nuestra lucha es pacifica estamos dispuestos a defender nuestras culturas, desde el convencimiento que ni el gobierno, ni los grupos armados, ni los hombres inminentes van a cambiar nuestras condiciones actuales, sino que seremos nosotros mismos, utilizando la educación que la madre tierra nos ofrece, unidos y organizados como pueblos indígenas. (Hougthon \& Villa, CRIC.10)

Entonces, se expide la Ley 397 de 1999 sobre patrimonio cultural, fomentos y estímulos a la cultura, y se crea el Ministerio de la Cultura para adecuar en el ordenamiento jurídico colombiano el reconocimiento de la cultura ligado al desarrollo sostenible. Estas determinaciones reconfiguraron las instituciones jurídicas que se encargarían de reconocer la propiedad colectiva de la tierra de los pueblos indígenas, en el contexto de la violencia, pero eliminan la autonomía indígena, en función de la soberanía estatal como lo expresaba Rajagopal (2005), lo que condujo a la construcción de una agenda nacional para el ejercicio de la justicia como reconocimiento, puesto que en estas instituciones jurídicas se tendría por objeto eliminar la injusticia cultural mediante políticas afirmativas, enfoques diferenciales que eliminaran procesos de negación social de los pueblos indígenas y de su cultura y por el contrario permitieran su afirmación.

Pero ello solo tendría por objeto afirmar simbólicamente la cultura con lo que se evitaba el ejercicio real de la diferencia, puesto que, para ello, se requería el reconocimiento de la autonomía del territorio, 
por fuera del contexto armado y de la disputa por la tierra y sus recursos en la que se encontraban los pueblos indígenas, quienes, más allá de la propiedad colectiva y de la consulta previa, requerían una justicia que condujera a una redistribución de la tierra que permitiera devolverles la tierra sin guerra, para garantizar su vida en comunidad.

Esto lo comprendieron los pueblos indígenas al inicio del siglo XXI, por lo cual volvieron a la movilización indígena que permitiera ubicar centros de lucha por el ejercicio de una resistencia por la tierra, y se reactivaran las luchas y las ocupaciones indígenas mediante instituciones de resistencia colectiva como fue La Minga.

Hougthon y Villa (2005) definen las mingas como actos de movilización colectiva con el fin de impedir la afectación de miembros de los pueblos indígenas por los grupos armados, cuentan con la característica del gran número de población que movilizan, mediante la cual han obtenido respuestas favorables a sus peticiones. El liderazgo de estas prácticas se realiza a partir de La Guardia Indígena, que se encarga de coordinar la movilización. Su práctica ha permitido bloquear la violencia de grupos armados, a excepción de los paramilitares, con quienes no se ha practicado este ejercicio de resistencia. La guardia indígena es comprendida como una organización que tiene por característica:

Una estructura voluntaria, compuesta en su mayoría por jóvenes, aunque no de manera exclusiva, organizada en forma celular y ostentosamente, desarmada con bastones de chonta que simbolizan autoridad, subordinada a los cabildos y sin capacidad para representar o establecer relaciones a nombre de las comunidades. Es sostenida mediante la comunidad por alimentos y aporte a medios de subsistencia, encargada de guiar la respuesta masiva de las comunidades frente a situaciones de violencia, y sobre todo de respuesta inmediata tanto a las orientaciones de sus autoridades como a las situaciones críticas. (Hougthon y Villa, 2005, p. 108)

Ha habido varias mingas indígenas, entre las cuales se destaca la de 2001, ejercida por la comunidad del Puracé contra los enfrentamientos entre el ELN y la Policía, quienes emplearon la música para paralizar el conflicto. En el mismo año, salieron 2000 indígenas de Jambaló 
y se tomaron la plaza central obligando a retirase a los narcotraficantes presentes en la región, evitando también una toma de la estación de Policía por las Farc.

Estas movilizaciones indígenas expresan la oposición a la guerra y la lucha por el reconocimiento a la autodeterminación de la tierra, contra la limitación legislativa de los derechos de los pueblos indígenas, lo que permite comprender la disminución presupuestal por el gobierno que, en 2001, tan solo destinó COP 159366 millones al ordenamiento social de la propiedad y en 2002 disminuyó a COP 90500 millones. La despreocupación estatal que se manifestó con un estudió que publicó el Instituto Agustín Codazzi en 2002, “donde mostró que 3500000 personas eran propietarios de predios rurales correspondientes a menos de 200 hectáreas y 7363 personas eran propietarios de territorios con una medida superior a 1000 hectáreas" (Houghton, 2008, p. 25), lo que expresa la desigualdad económica y social en el territorio colombiano, y la imperiosa necesidad de redistribuir las tierras.

Esto se ubicó en la construcción de una justicia que producía el reconocimiento pero que consolidó la injusticia económica que este panorama permitía percibir, ya que mientras se aislaba el problema de la redistribución de los recursos se creó mediante la Ley 649 de 2001 una norma de la "circunscripción nacional especial para asegurar la participación en la Cámara de Representantes de los grupos étnicos, las minorías políticas y los colombianos residentes en el exterior", otorgándoles a los líderes de las comunidades indígenas que sean reconocidos por el Estado mediante un certificado emitido por la Comunidad y refrendado por el Ministerio del Interior. Además, se impulsó un sistema de salud de los pueblos indígenas mediante el Decreto 330 de 2001, cuyo desarrollo se hizo por medio de los Decretos 2716 de 2004, 4127 de 2005 y 4972 de 2007 que reglamentaron las Administradoras Indígenas de Salud, ARSI, y Entidades Promotoras de Salud Indígenas, EPSI, que actualmente se encuentran operando en el régimen subsidiado y las que se conformaron deberán acreditar, como mínimo, el $60 \%$ de sus afiliados. Sin embargo, la adecuación del servicio no permite garantizar un modelo de atención integral e intercultural en salud, ni la medicina tradicional se encuentra articulada al sistema nacional de Seguridad Social en Salud. 
En 2003, se aprueba una reforma agraria que tenía como propósito “democratizar la propiedad", lo que condujo a liquidar las instituciones gubernamentales como: INAT, INCORA, INPA, DRI, y las reunifica en el INCODER. Este tendría por función fomentar el desarrollo rural para la explotación económica cuyo efecto fue la destrucción del ambiente de bosques, flora y fauna en el territorio como efectos secundarios de la incorporación del denominado "Desarrollo económico". También, se iniciaron procesos administrativos de restitución de tierras a los terratenientes que, por la lucha indígena de las décadas de los setenta y los ochenta, habían perdido. Este mismo año, coincide con el préstamo otorgado por el Banco Mundial al gobierno nacional de USD 32 millones para incorporar cadenas de producción. En materia del presupuesto para el reconocimiento de la tierra a favor de los pueblos indígenas, en 2003 se tenían presupuestados COP 6133 millones, de los cuales se ejecutaron COP 1280 millones con los que se compraron dos fincas en Antioquia y Cauca.

En 2004, se dio una vuelta al paradigma de los noventa en las luchas indígenas por su reivindicación territorial. En 2005, solo el $13 \%$ de los recursos estatales fueron destinados al ordenamiento social de la propiedad, es decir COP 1030 millones de los cuales se ejecutaron solamente COP 554009000 para la adquisición de tierras indígenas en todo el territorio colombiano. Mientras que en 2006, se ejecutaron COP 2264 millones para adquirir 4 predios para los territorios indígenas en el Amazonas, Tolima y Quindío. Sin embargo, en este mismo año, el Estado se vio obligado a adquirir 15663 hectáreas de tierra para reparar a las víctimas de la masacre del Nilo (de las cuales solo 9047 hectáreas fueron entregadas en esa fecha y de ellas solo 3619 hectáreas eran tierras fértiles), dada la presión política del desarrollo de las tres relevantes mingas indígenas cuyo objetivo era recuperar su autonomía indígena liberando a tres de sus líderes, una fue en la Fiscalía de Santander de Quilichao, la otra en San Vicente del Caguán que pedía a las Farc la liberación de uno de sus líderes y la última tuvo lugar en la Fiscalía de Bogotá.

Entre 2006 y 2007, los recursos del Estado en materia de propiedad tuvieron por destino el subsidio empresarial rural por la afectación del TLC, que fue solo el $27 \%$ de los recursos destinados al ordenamiento 
social de la propiedad. En el año 2008, en la presidencia de Álvaro Uribe Vélez, se manifiesta un contexto de fracaso de la Reforma Constitucional, pues se olvidó la diversidad cultural y étnica, que fue un olvido de los pueblos indígenas ante una promesa incumplida por los gobiernos de la autonomía reconocida por la Carta Constitucional y el incumplimiento del Estado en las obligaciones contraídas en los acuerdos de reparación patrimonial por la masacre de El Nilo se examina en la siguiente relación: "1991-2001: 8598 hectáreas por un valor COP 23824 millones y 2002-2008: 3267 hectáreas por un valor de COP 16237 millones, para un total de 11865 hectáreas por un valor de Cop 40061 millones" (Presidencia de Colombia, 2008, p. 4). Esto permite concluir que las hectáreas de tierra prometidas fueron 15663 y que faltan 3798 hectáreas por entregar. Este incumplimiento produjo un descontento en la organización indígena que convocó a una movilización indígena de resistencia, que llamaron "Mínga Nacional Indígena", también conocida como "Gran Minga por la vida”. El 12 de octubre del 2008, entre 45000 y 60000 indígenas partieron del Departamento del Valle del Cauca hasta Bogotá. En la marcha, se produjo el asesinato, el 16 de diciembre de 2008, del esposo de una líder indígena del CRIC, Edwin Legarda, que recibió tres disparos del ejército. Estos hechos tuvieron una manifestación de varias organizaciones internacionales como Amnistía Internacional y el PNUD, que lamentaron el hecho, lo que condujo a que, el 17 de diciembre, el presidente tuviera que ofrecer disculpas por lo ocurrido. Los cinco puntos de la minga fueron:

1. No aceptamos "Tratados de Libre Comercio" porque tienen el propósito de despojarnos de nuestros derechos, culturas, saberes y territorios.

2. Rechazamos y exigimos la derogatoria de las reformas constitucionales y legales que sirven a los intereses del modelo económico y a la codicia transnacional.

3. Denunciamos el terror y la guerra como estrategias de despojo que en Colombia se implementan a través del Plan Colombia y la política de Seguridad Democrática. 
4. Exigimos el cumplimiento de normas, acuerdos y convenios que se ignoran de manera sistemática. Pero no exigimos solamente como indígenas. Todas las causas son nuestras.

5. Construyamos la Agenda de los Pueblos. Nos comprometemos a compartir y sentir el dolor de otros pueblos y procesos. Tejido de dolor que se haga camino para que esta institucionalidad ilegítima al servicio del capital transnacional sea reemplazada por un Gobierno Popular Sabio. (ONIC, 2015)

En el año 2009, la ONIC y el CECOIN presentaron un informe paralelo sobre la situación de los pueblos indígenas en el que consideran que estos pueblos son víctimas del conflicto armado, lo que se asume como un factor que ha impedido el reconocimiento de sus derechos a la propiedad colectiva, a la autodeterminación y a la diversidad cultural y étnica. En este estudio, se destacan los siguientes datos ${ }^{7}$ :

Tabla 17. Conclusiones del informe de la ONIC y el CECOIN sobre la situación de los pueblos indígenas

\begin{tabular}{|l|c|c|c|l|}
\hline \multicolumn{1}{|c|}{ Tema } & $\begin{array}{l}\text { Total de } \\
\text { víctimas }\end{array}$ & $\begin{array}{l}\text { Total de } \\
\text { mujeres }\end{array}$ & $\begin{array}{c}\text { Total de } \\
\text { hombres }\end{array}$ & \multicolumn{1}{|c|}{ Datos relevantes } \\
\hline $\begin{array}{l}\text { Asesinatos políticos } \\
\text { por pueblo indígena. } \\
\text { Colombia 1974-2009 }\end{array}$ & 2351 & 2026 & 185 & $\begin{array}{l}\text { Pueblo con mayor } \\
\text { afectación nasa (634), } \\
\text { Kamnkuamo (249) } \\
\text { y wuayúu (241) }\end{array}$ \\
\hline $\begin{array}{l}\text { Acciones bélicas contra } \\
\text { pueblos indígenas } \\
\text { 1974-2009 }\end{array}$ & 6904 & 2650 & 2045 & $\begin{array}{l}\text { Los años de mayor } \\
\text { afectación: 2005, 2006 } \\
\text { y 2007. }\end{array}$ \\
\hline $\begin{array}{l}\text { Amenazas colectivas } \\
\text { contra indígenas } \\
\text { periodo 1974-2009 }\end{array}$ & 8792 & 3861 & 1625 & $\begin{array}{l}\text { Los años de mayor } \\
\text { afectación: 1997, 1998 } \\
\text { y 2005 }\end{array}$ \\
\hline $\begin{array}{l}\text { Desaparición forzada } \\
\text { contra pueblos } \\
\text { indígenas 1974-2009 }\end{array}$ & 338 & 246 & 41 & $\begin{array}{l}\text { 2004, año de mayor } \\
\text { afectación. }\end{array}$ \\
\hline
\end{tabular}

7 Información retomada del informe propuesto por la CECOIN: (2009, pp. 35-40). 


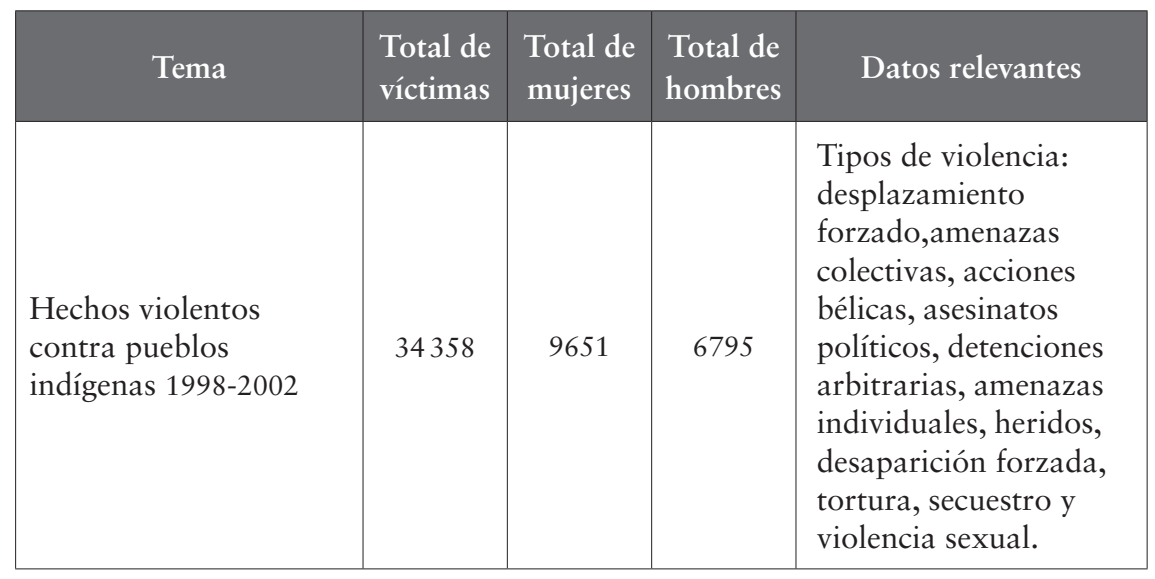

Fuente: CECOIN (2009, pp. 35-40)

En el año 2010, la ONIC presentó el informe en relación con la violación de los derechos de los pueblos indígenas a partir de las políticas gubernamentales del gobierno de Santos, en el que se destaca la preocupación por la locomotora minero energética y su relación con la destrucción de los territorios de los pueblos indígenas, de los que se dice que se habían otorgado hasta el mes de agosto del 2010 un total de 8827 títulos a empresas extractivas, de los cuales, 571 son zonas de protección forestal, donde la minería estaría prohibida de acuerdo con la legislación colombiana. Otra preocupación es la legitimación del gobierno para dejar de invertir en el gasto público, lo que conduce a desconocer los derechos a la tierra de los pueblos indígenas bajo el argumento de la sostenibilidad fiscal, articulado como derecho mediante el "Proyecto de Acto legislativo 016 de 2010". Posteriormente, se examinan las estadísticas de las afectaciones del conflicto armado sobre los pueblos indígenas, y se hace una acotación especial sobre la necesidad de protección inmediata que requiere el pueblo Nukak Maku, como consecuencia de prácticas de culturas como es el caso de:

Proceso de desaparición étnica se da en términos culturales y por acción del acelerado proceso de integración a la sociedad dominante debido al desplazamiento forzado como el caso de los Wayari, la presencia de grupos al margen de la ley y relaciones laborales, 
la situación alimentaría que produce desnutrición, las enfermedades que los diezman, las condiciones de vivienda y hacinamiento que crean espacios para la proliferación de enfermedades, estrés y maltrato intrafamiliar, son varias de las causas que están conduciendo al etnocidio del pueblo Nukak. (ONIC, 2010 p. 16)

Entre las conclusiones de este informe se destaca que en 2010 se registró un total de 122 indígenas asesinados, la consulta previa ha sido omitida de manera reiterada y la causa de los asesinatos en su gran mayoría está articulada a proyectos de explotación liderados por el Estado, y, si se continúa la lamentable situación del pueblo Nukak Maku, se puede llegar a un etnocidio cultural y a la muerte física de este pueblo.

Este contexto de violencia y de introducción de sistemas de explotación minero-energética acelerados en el país, junto con el ejercicio práctico del TLC generó la consolidación de la "Minga Social indígena y popular. Por la vida, el territorio, la autonomía y la soberanía” en octubre de 2013, celebrada en el Resguardo La María (Piendamó, Cauca) cuyas exigencias son 29 acuerdos, los cuales tratan sobre los ejes: protección ante la política minero-energética, Derechos Humanos, conflicto armado y paz y autonomía jurídica y político-administrativa. En abril de este año, ya se había celebrado una "Minga Indígena Nacional por la Paz y la Reconciliación del País” en Medellín, cuya preocupación principal era la partición en la "agenda indígenas de la paz”. También se participó con solidaridad por la democracia y la no destitución de Gustavo Petro como Alcalde de Bogotá en mayo de este año.

Estas acciones conjuntas permiten observar la relevancia en la organización indígena de la institución de la minga como práctica del derecho a la resistencia, mediante la cual han obtenido conquistas cruciales en materia de derechos, así como la visibilidad global de sus principales dificultades en relación con el territorio, la autonomía y la cultura. Estas amenazas y estos triunfos han sido llevados en informes alternos ante las Naciones Unidas de manera sistemática. Estas acciones han procurado evitar la vulneración de sus derechos a la tierra, a la autodeterminación y a la cultura, y en algunos casos a su posible desaparición como es el caso de los Nukak Maku. Así mismo, es preciso resaltar la relevancia que le ha otorgado el movimiento indígena 
al conflicto armado, pues ha participado en la lucha contra la violencia mediante la resistencia en la minga indígena.

\section{Incumplimiento de la redistribución de la tierra y del reconocimiento de la autonomía y la cultura de los pueblos indígenas}

Después de la presión realizada por la resistencia indígena en las mingas, se realizaron compras de tierras y de ampliación de los resguardos a favor de los indígenas aunque ha continuado el incumplimiento parcial de los acuerdos con el gobierno nacional. En efecto, en 2009, año en el que se expidió el Acuerdo 185 del 30 de septiembre, con el cual se buscó la ampliación del Resguardo Embera Katio Eyabida de Doxerazabí, en el que se manifiesta la adquisición de cuatro predios en el Municipio de Turbo, Antioquia, en busca de ampliar el resguardo, en cumplimiento del acuerdo, que posteriormente se debilitó entre 2010 y 2014, cuando el InCODER, bajo el Plan Nacional de Desarrollo "Prosperidad para todos" asumió un "enfoque territorial de desarrollo rural" cuyo efecto sobre los pueblos indígenas es el siguiente:

(2011): El presupuesto de adquisición de tierras para las comunidades indígenas del Cauca fue de COP 15000 millones con lo que se programó la adquisición de 43 predios, sin embargo solamente se ejecutaron COP 2750 millones. En el caso del Proyecto del Saneamiento de Resguardo Unido U’wa ${ }^{8}$ se tenía un presupuesto de COp 3000 millones de los cuales se tuvo un avance del $7 \%$, ejecutando COP 1415000 del dinero presupuestado» (INCODER, 2014). En saneamiento de resguardos de la totalidad del territorio nacional se tenía un presupuesto de COP 4000 millones de los cuales tan solo se ejecutaron COP 170 millones, para la adquisición y adjudicación de tierras indígenas y afros se tenía destinada

8 Tema de análisis en el capítulo tercero, pues, con la ubicación de un pozo petrolero se generaron acciones industriales que pusieron en grave peligro el territorio y la vida cultural de la comunidad hasta la actualidad. 
la suma de COP 12000 millones de las cuales solo se emplearon COP 2011100 000. (INCODER, 2014, 62)

En 2012, se tenía un "presupuesto de COP 19320 millones de los cuales se ejecutó el $66.5 \%$ pero de este dinero ejecutado el $0 \%$ fue destinado a la adquisición de tierras para las comunidades indígenas del Cauca" (INCODER, 2014). Igual fue la situación del dinero destinado para el saneamiento del Resguardo Unido U'WA en Boyacá y Norte de Santander, donde no se ejecutó este presupuesto.

En 2013, se tenía "estimado COP 35574766327 a favor del reconocimiento de la propiedad colectiva de los pueblos indígenas, específicamente en la constitución, ampliación y saneamiento de sus territorios tradicionales. No obstante, de esta cifra se utilizaron solamente COP 16880429 , de los cuales el $0 \%$ fueron utilizados en beneficio de los U’wa” (INCODER, 2014).

En 2014, "se tenían destinados COP 39949634837 para el programa de legalización de tierras y fomento para el desarrollo rural de las comunidades indígenas a nivel nacional, de los cuales gastaron el $52 \%$, correspondiente a una cifra de COP 20574939476 " (INCODER, 2014).

De acuerdo con los informes presentados por el INCODER entre 2010 y 2014 y su informe final, consolidado en el año 2014, es posible determinar el número de hectáreas que se les reconocieron a los pueblos indígenas:

Tabla 18. Hectáreas reconocidas a los pueblos indígenas

\begin{tabular}{|c|l|}
\hline 2010 & 108110 hectáreas \\
\hline 2011 & 57265 hectáreas \\
\hline 2012 & 22966 hectáreas \\
\hline 2013 & 527288 hectáreas \\
\hline 2014 & 6813 hectáreas \\
\hline $2010-2014$ & $\begin{array}{l}\text { Total de hectáreas a favor de los pueblos indígenas: } \\
722422 \text { hectáreas }\end{array}$ \\
\hline
\end{tabular}

Fuente: INCODER (2014) 
Es posible concluir que los pueblos indígenas han sufrido el impacto del conflicto armado en la vida individual y colectiva, pues los asesinato, las persecuciones de líderes, el desplazamiento forzado, las masacres, las violencia sexual contra las mujeres, las niñas y los niños indígenas, el reclutamiento forzado ha impedido el desarrollo de la resistencia cultural y territorial de la Organización Indígena de Colombia lo que ha reducido a los pueblos indígenas a la pobreza, el aislamiento de los territorios ancestrales, la pérdida de la unidad como pueblos colectivos, lo que los ha llevado incluso al exterminio étnico como ocurre con los Nukak Maku. Estas condiciones requieren examinar la participación de los indígenas en los foros de participación ciudadana para buscar la articulación de un enfoque diferencial étnico que atienda el impacto de la violencia y permita repararlos y eliminar toda posibilidad de revictimización, según criterios que busquen la adecuación político económica y sociocultural que estos requieren, con respeto por su autonomía, y por las tierras y las culturas de nuestros pueblos indígenas en la construcción de la paz.

\section{Los pueblos indígenas en los foros de participación ciudadana}

El propósito del Primer foro de participación ciudadana fue construir una propuesta para modernizar y mejorar la calidad de vida, equilibrar las condiciones entre la ciudad y el campo, que ha sido causa y efecto del conflicto colombiano. Para ello, se busca un ordenamiento social y ambiental del territorio que permita cumplir estos objetivos, según enfoques diferenciales que para los Pueblos Indígenas, la ONIC planteó la necesidad de reconocer la pertenencia continua y sostenible de los pueblos indígenas en sus territorios con un enfoque étnico y de género que permita el reconocimiento de su derecho colectivo a la tierra y al territorio. Para ello, propusieron definir límites a la propiedad privada, reconociendo el derecho a la propiedad colectiva, impidieron la inclusión en sus territorios colectivos y en territorios afro de zonas campesinas de actores armados. Proponen la creación de un Foro de acceso a la tierra en el que puedan participar indígenas, afrodescendientes y campesinos y donde se puedan determinar de manera 
precisa sus pretensiones. Así mismo, le pidieron al gobierno legalizar las tierras y los territorios colectivos, "rechazando una titulación individual y aceptando una titulación colectiva" (Universidad Nacional, 2012, p. 43). Manifestaron la necesidad de sanear los predios de los parques naturales donde se pueda ejercer su derecho de autodeterminación en materia de propiedad colectiva.

La Organización Indígena de Colombia argumentó que la solución pacífica del conflicto armado no es la paz del país, pero esta es un inicio y para ello se debe garantizar la permanencia de las poblaciones en sus territorios de manera sostenible, y con garantía de los derechos económicos, sociales y culturales. Esta propuesta parte de reafirmar la propiedad ancestral, tanto titulados y no titulados en conjunto: resguardos, territorios colectivos, zonas de reserva campesina, bajo la figura jurídica de territorios interétnicos. Bajo el principio de progresividad, según el cual no se puede atentar contra los derechos previamente reconocidos, siendo esta la principal preocupación del Acuerdo. Además, se deben valorar las visiones diferentes del desarrollo de los pueblos de acuerdo con cada cultura y cada pueblo, puesto que "el territorio es la base de su cultura, su identidad y su vida" (Universidad Nacional, 2012, p. 33). Le piden al Estado responder las 600 solicitudes de aclaración del uso y la propiedad sobre territorios indígenas, y rechazan la creación de parques naturales en territorios indígenas.

En materia de coca se plantea que la necesidad primordial en este aspecto es la "Exigencia de devolver los indígenas reclutados por las guerrillas”, y fortalecer la guardia indígena, como forma de expresión sociocultural para la defensa de sus comunidades, la importancia de proteger su lengua, sus prácticas culturales y su tejido social. Para ello, es necesario realizar un censo que permita conocer la población indígena en Colombia, su ubicación y la riqueza de su patrimonio cultural. Se propusieron 50000 hectáreas para el cultivo de la coca y la marihuana, que serían destinados para los usos tradicionales que los pueblos indígenas han ejercido como parte de su cultura, por lo cual se pide considerar este territorio como zonas especiales de desarrollo y su legislación progresiva.

Se propuso conformar territorios interétnicos que incluyan tanto a indígenas, afrodescendientes y campesinos según una visión de 
territorio intercultural. Para ello, se requieren encuentros interétnicos que solucionen los conflictos en materia de territorio. Se hizo una especial mención de la necesidad de reconocer el territorio intercultural del Pueblo Barí, así como "la Comunidad interétnica del Catatumbo entre indígenas y campesinos" (Universidad Nacional, 2012, p. 44). Se exige al Estado realizar una consulta previa real en materia de tierras como en los efectos que se generen con el presente Acuerdo, y de extenderla a los campesinos. Igualmente, todas las organizaciones plantearon la necesidad de detener la "locomotora minero energética", y una medida probable es la "derogación de la ley 1450 del Plan de Desarrollo prosperidad para todos para sustraer la Amazonia de la cordillera oriental, el piedemonte y la llanura amazónica" (Universidad Nacional, 2012, p. 51).

Durante el segundo Foro de Participación Ciudadana, llevado a cabo en 2013, se ubica la participación de los Pueblos Indígenas mediante la representación de la ONIC. En las ponencias presentadas, se destaca la del vocero Luis Fernando Arias, titulada: "Pensando un Nuevo Paradigma de Participación Política en Colombia”. En esta ponencia se interpela la necesaria articulación de la participación, la autonomía, la territorialidad, la colectividad y la gobernanza popular campesina, indígena y afrocolombiana. En el discurso de la participación política interétnica se busca garantzar la oposición entre lo urbano y lo rural, entre lo local, lo regional y lo nacional, y atender a los principios de gobernanza popular e interétnica, siendo una manifestación de esta figura los resguardos indígenas, los territorios colectivos y las zonas de reserva campesina. "Promover una visión y una acción política desde la diversidad, transformadora desde el imaginario de Nación convencional y del modelo de desarrollo vigente" (Universidad Nacional, 2012, p. 127).

Igualmente, se encuentra la ponencia de las Autoridades Indígenas de Colombia (AICO) a cargo de Luis Humberto Cuaspud, que se titula "Derecho a la Participación para la Autonomía". En este texto se argumentan las luchas históricas de los pueblos indígenas por la defensa a la autonomía, consagrada en la Constitución de 1991, en la cual, hasta la fecha, el contenido de la autonomía no ha sido comprendida, y se ha manifestado en la discriminación, la exclusión y el exterminio 
cultural. Es por ello que su intervención busca proponer la necesidad de sostener las entidades territoriales indígenas, como condición inicial de la participación.

En la primera relatoría, se ubica la necesidad de construir un Estatuto de Oposición con enfoque diferencial que reconozca a los pueblos indígenas y afrodescendientes según sus diferencias. En la segunda relatoría, se propone construir mecanismos de participación directa que integren a los pueblos indígenas, y se les reconozca la autonomía y de sus derechos territoriales. En la construcción de estos mecanismos, se debe garantizar el ejercicio de la consulta previa a los pueblos indígenas, junto con la construcción especial de mecanismos de participación especiales para víctimas indígenas del conflicto que busquen su reparación y no algún tipo de re-victimización.

Se ubica como medida necesaria en la participación política la necesidad de modificar la consulta previa que, en la práctica material, no sea una consulta simple, sino que asuma una respuesta decisoria la manifestación que en ella hagan los pueblos indígenas. Se propone crear un cuarto poder, denominado: Poder Popular. En este, los pueblos indígenas afirmaron la importancia de continuar reconociendo su autonomía política y judicial. 
